\title{
Cell membrane biology during apoptosis: the role of annexin A5
}

Citation for published version (APA):

Kenis, H. (2005). Cell membrane biology during apoptosis: the role of annexin A5. [Doctoral Thesis, Maastricht University]. Maastricht University. https://doi.org/10.26481/dis.20050922hk

Document status and date:

Published: 01/01/2005

DOI:

10.26481/dis.20050922hk

Document Version:

Publisher's PDF, also known as Version of record

\section{Please check the document version of this publication:}

- A submitted manuscript is the version of the article upon submission and before peer-review. There can be important differences between the submitted version and the official published version of record.

People interested in the research are advised to contact the author for the final version of the publication, or visit the DOI to the publisher's website.

- The final author version and the galley proof are versions of the publication after peer review.

- The final published version features the final layout of the paper including the volume, issue and page numbers.

Link to publication

\footnotetext{
General rights rights.

- You may freely distribute the URL identifying the publication in the public portal. please follow below link for the End User Agreement:

www.umlib.nl/taverne-license

Take down policy

If you believe that this document breaches copyright please contact us at:

repository@maastrichtuniversity.nl

providing details and we will investigate your claim.
}

Copyright and moral rights for the publications made accessible in the public portal are retained by the authors and/or other copyright owners and it is a condition of accessing publications that users recognise and abide by the legal requirements associated with these

- Users may download and print one copy of any publication from the public portal for the purpose of private study or research.

- You may not further distribute the material or use it for any profit-making activity or commercial gain

If the publication is distributed under the terms of Article $25 \mathrm{fa}$ of the Dutch Copyright Act, indicated by the "Taverne" license above, 
(c) Heidi Kenis, Maastricht 2005 ISBN 90-5278-476-0

Printed by: Datawyse Maastricht Cover design by Arch. Carl L.F. Augustijns 


\title{
CELL MEMBRANE BIOLOGY DURING APOPTOSIS \\ THE ROLE OF ANNEXIN A5
}

\author{
PROEFSCHRIFT \\ ter verkrijging van de graad van doctor \\ aan de Universiteit Maastricht, \\ op gezag van de Rector Magnificus, \\ Prof. mr. G.P.M.F. Mols, \\ volgens het besluit van thet College van Decanen, \\ in het openbaar te verdedigen \\ op donderdag 22 september 2005 om 14.00 uur \\ door \\ HEIDI KENIS
}

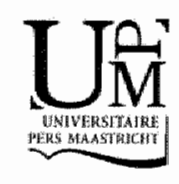




\section{PROMOTOR}

Prof. dr. J. Rosing

CO-PROMOTORES

Dr. L. Hofstra

Dr. C.P.M. Reutelingsperger

\section{BEOORDELINGSCOMMISSIE}

Prof. dr. H.J.G.M. Crijns (voorzitter)

Prof. dr. J. Narula (University of California Irvine, Irvine, USA)

Prof. dr. F.C.S. Ramaekers

Prof. dr. J.F.M. Smits

Prof. dr. H.A.J. Struijker Boudier

This study was performed at the Cardiovascular Research Institute Maastricht (CARIM).

Financial support by RESCAR, Philips Medical Systems, Nexins Research and Leica Microsystems $n . v$. for publication of this thesis is gratefully acknowledged. 


\section{CONTENTS}

$\begin{array}{lll}\text { Chapter } 1 & \text { General introduction } & 7\end{array}$

1. Apoptosis 8

1.1. History of apoptosis

1.2. Morphological and biochemical changes

1.3. Role of apoptosis in the pathogenesis of diseases

1.4. Plasma membrane asymmetry

1.5. Clearance of apoptotic cells

1.6. Apoptosis and thrombosis

2. Annexins

2.1. Annexin A5

2.2. Imaging of apoptosis with annexin A5

3. Aim of this thesis

Chapter 2 Mutation analysis of annexin A5 and the risk of the C-1 mutation on myocardial infarction and venous thrombosis.

Chapter 3 Reversibility of phosphatidylserine externalization and apoptosis in the ischemic heart.

Chapter $4 \quad$ Cell surface expressed phosphatidylserine and annexin A5 open a novel pathway of cell entry.

Chapter 5 Annexin A5 inhibits engulfment of apoptotic cells through internalization of phosphatidylserine-expressing cell membrane patches.

Chapter $6 \quad$ General discussion

Samenvatting 


\section{CHAPTER 1}

\section{GENERAL INTRODUCTION}




\section{APOPTOSIS}

\section{SUMMARY}

Apoptosis, also called programmed cell death, plays a crucial role in tissue homeostasis in multi-cellular organisms. A balance between proliferation and cell death is essential to maintain homeostasis. Dysregulation of apoptosis forms the basis of a variety of diseases. For instance, insufficient removal of unwanted cells may lead to diseases such as cancer and auto-immune disorders. On the other hand, increased apoptosis is associated with diseases such as neuro-degeneration and myocardial infarction. Modulation of apoptosis may, therefore, provide attractive therapeutic opportunities to treat the before mentioned diseases. One of the distinctive features of apoptosis is blebbing of the plasma cell membrane and the loss of plasma cell membrane asymmetry. The latter is characterized by the rapid exposure of phosphatidylserine (PS), a membrane phospholipid. In vitro studies have shown that the exposure of PS plays a role in the removal of apoptotic cells. Furthermore, the plasma membrane changes during apoptosis are associated with enhancement of thrombus formation. Annexin A5 is a plasma protein, which has a strong affinity for exposed PS. However, the exact role of annexin A5 on the cell membrane biology during apoptosis remains poorly understood.

\subsection{HISTORY OF APOPTOSIS}

The initial discovery of cell death in 1842 by Carl Vogt was recognized five years after the Cell Theory was proposed and then dropped for 130 years. In 1972, Kerr et al. coined the term apoptosis (derived from the Greek word for 'falling off') to describe programmed cell death on basis of the following morphological criteria: membrane blebbing, shrinking of the cytoplasm, condensation of the nucleus and formation of apoptotic bodies ${ }^{1}$. Later on, in the late eighties and nineties, biochemical changes have been reported such as DNA fragmentation and PS exposure. Today, apoptosis is perhaps the most widely researched topic in medical biology.

\subsection{MORPHOLOGICAL AND BIOCHEMICAL CHANGES}

Apoptosis is characterized by a sequence of morphological alterations. Following activation of the cell death program, the cell shrinks, the plasma 
membrane blebs and the nucleus condenses and fragmentates. The biochemistry underlying these morphological changes depends on the activation and action of caspases". Caspases, which constitute a family of cysteine-dependent aspartate-directed proteases, reside in the cytosol and intracellular organelles like mitochondria and endoplasmic reticulum as dormant zymogens. They are awakened by proteolysis and, once activated, build a cascade of activated caspases, which generates a proteolytic burst within the cell resulting in cytochrome $\mathrm{c}$ release from the mitochondria and activation of the executioner caspase, caspase $3^{2}$.

Two apoptotic pathways have been described in mammalian cells which are triggered via caspases; the death-receptor pathway (extrinsic activation via receptor/ligand associated signal transduction) and the mitochondrial pathway (intrinsic activation via the formation of the apoptosome) $)^{3}$.

\subsection{ROLE OF APOPTOSIS IN THE PATHOGENESIS OF DISEASES}

It is now well established that apoptosis is an essential part of normal development and tissue homeostasis, which is not only determined by a spatiotemporally controlled initiation of the cell death program but also by the phagocytic removal of dying cells without eliciting an inflammatory reaction. Equally, or perhaps even more, important is the role of apoptosis in the pathogenesis of human disease. Failure to invoke appropriate cell death can result in congenital malformations ${ }^{4}$, autoimmune disease or cancer ${ }^{5}$, whereas increased cell death occurs in acute pathologies such as infection by toxinproducing micro-organisms, cardiovascular diseases ${ }^{6}$ as well as in chronic diseases such as immunodeficiency and neurodegenerative disorders ${ }^{7}$. Tight control of the apoptotic machinery is critical for cellular survival. On top of being a cause of disease, apoptosis may also be employed as a target in the clinic to treat diseases. For instance, many anti-cancer therapies such as chemo- and radiotherapy are effective because they induce apoptosis of the tumor cells ${ }^{5}$.

Apoptosis is the most abundant form of programmed cell death (PCD). Nevertheless, other forms of PCD have been distinguished: apoptosis-like PCD, necrosis-like PCD and necrosis ${ }^{8}$. Apoptosis-like PCD is characterized by a less compact chromatin condensation, PS exposure before cell lysis and is mostly caspase-independent. Necrosis-like PCD is characterized by the absence of chromatin condensation, PS exposure before cell lysis and is not caspase 
initiated. Necrosis or "accidental cell death" is defined as a passive and nonspecific process resulting in cell death after chemical and physical injury. Necrotic cell death is often associated with extensive tissue damage resulting in an intense inflammatory response. In comparison to apoptosis, they all differ in morphology and biochemistry but they share one common caracteristic: PS exposure.

\subsection{PLASMA MEMBRANE ASYMMETRY}

The plasma membrane of healthy cells is characterized by an asymmetric distribution of the various phospholipids over the two membrane leaflets ${ }^{9}$. The inner leaflet, facing the cytosol, contains phosphatidylserine (PS), phosphatidylinositol, phosphatidylethanolamine and phosphatidylcholine. The outer leaflet, facing the environment, harbours phosphatidylethanolamine (but to a lesser extent than the inner leaflet), phosphatidylcholine and sphingomyelin. This asymmetry is generated and maintained by energy-dependent processes, which rely on the activity of a so-called aminophospholipid translocase (APT). APT is defined by its ability to transport phosphatidylethanolamine and PS from the outer to the inner leaflet, but the mechanism of phospholipid translocation has not been identified at the molecular level thus far.

\subsubsection{PHOSPHATIIDYLSERINE EXPOSURE DUIRING APOPTOSIS}

In 1992 "Fadok et al. showed that apoptotic cells expose PS at their surface ${ }^{10}$. During apoptosis, PS is translocated to the outer leaflet of the plasma membrane by inactivation of the aminophospholipid translocase (APT) and activation of a phospholipid scramblase (PLSCR) $)^{11,}{ }^{12}$ (Figure 1). The phospholipid scramblase (PLSCR) is a bi-directional ATP-independent transporter that randomly translocates phospholipids from the inner to the outer leaflet and vice versa. The nature of the PLSCR is not fully understood. It has been described unambiguously only by biological activity. The appearance of PS on the outer leaflet of the membrane during apoptosis triggers their uptake by phagocytes without eliciting an immune response. PS exposure can be triggered by: 1) a calcium flux across the membrane resulting in inactivation of APT and activation of $\mathrm{PLSCR}^{13} ; 2$ ) cytochrome c release ${ }^{14}$ and 3) caspases since a broad-spectrum caspase inhibitor, prevents PS exposure ${ }^{115}$. Besides the caspase-dependent PS exposure, caspase-independent externalization of PS has also been described (see other forms of PCD). However, alternative routes leading to PS exposure may occur before the point of no return. 


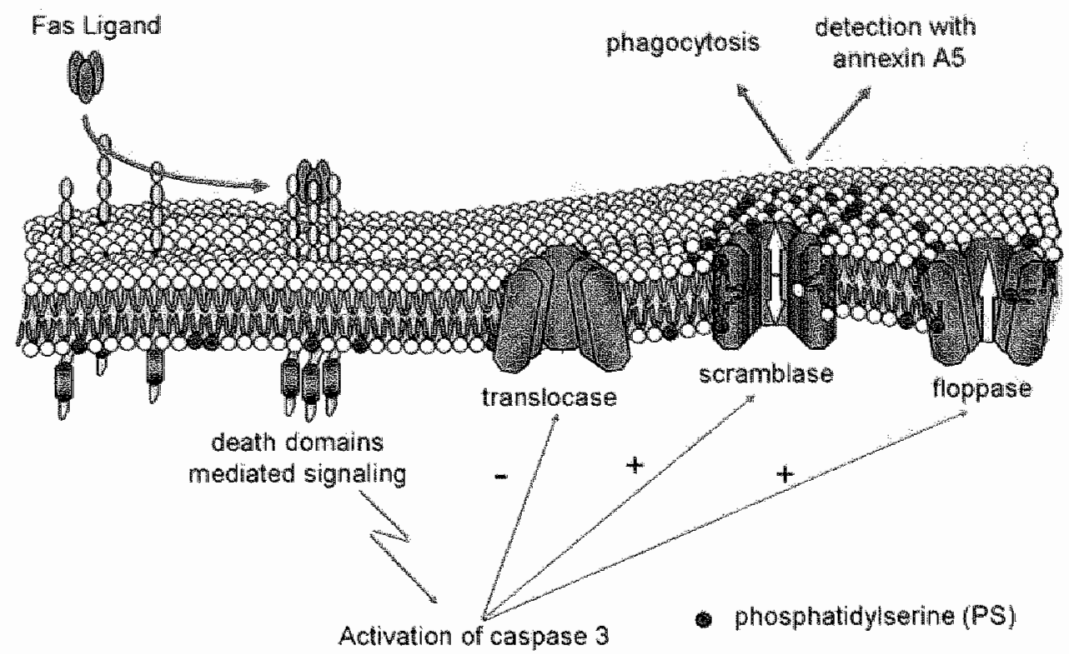

Figure 1 PS exposure during apoptosis.

\subsubsection{PHOSPHATIDYLSERINE EXPOSURE NOT RELATED TO APOPTOSIS}

Loss of phospholipid asymmetry, with consequent exposure of PS in the outer leaflet of the plasma membrane, appears not only to be a key feature of apoptosis but also plays an important role in several other physiological processes. PS exposure has been reported in living cells. For example, murine bone marrow $B$ cells expose PS without executing apoptosis ${ }^{16}$. During fusion of myoblasts to form multinucleated myotubes ${ }^{17},{ }^{18}$ and during fusion of cytotrophoblast cells to form the syncitiotrophoblast of the placental chorionic villi ${ }^{19}$, temporarily exposed PS may be required to facilitate the fusion process. Moreover, PS externalization in spermatozoa cells during capacitation is believed to facilitate the formation of the zygote. Shi et al. showed that in a rat endotoxemia model, Kupffer cells could phagocytose neutrophils that did not display DNA fragmentation, but stained in vivo with annexin A5, suggesting that neutrophils ingested by Kupffer cells were not apoptotic ${ }^{20}$. In a similar way, neutrophils in patients with the Barth Syndrome (BTHS) bind annexin A5 in the absence of apoptosis ${ }^{21}$. However, these neutrophils were not phagocytosed by macrophages. Galectin-1 induces PS exposure and phagocyte recognition in human leukocytes without inducing apoptosis ${ }^{22}$. Recently, Callahan et al. showed that PS exposure of differentiating monocytes is required for phagocytosis of apoptotic cells ${ }^{23}$. Activated platelets and chlamydia infected 
cells externalize PS, resulting in blood coagulation ${ }^{24-28}$. However, the molecular mechanisms responsible for PS translocation in both apoptotic and nonapoptotic cells are still under investigation.

Whatever the mechanism is, it is widely accepted that PS exposure on apoptotic cells is the best characterized "eat me" signal recognized by phagocytes.

\subsection{CLEARANCE OF APOPTOTIC CELLS}

The clearance of apoptotic cells by phagocytes, called phagocytosis, is primarily mediated via PS, which serves as an "eat me" signal for the recognition by phagocytes.

\subsubsection{PHAGOCYTOSIS}

Similar to apoptosis, phagocytosis is a phylogenetically conserved process that plays an essential role in the resolution of inflammation. It was first observed by Elie Metchnikoff, a Russian biologist who in the late $19^{\text {th }}$ century observed that 'microphages' were englobed by macrophages. Today, phagocytosis is defined as the cellular engulfment of large particles $(>0.5 \mu \mathrm{m})$ such as pathogens or tissue debris that accumulate during infection and wound repair. Such particles are rapidly cleared by professional phagocytes, such as macrophages and dendritic cells or by semi-professional phagocytes in the surrounding tissue such as mesangial cells. Thus, phagocytosis is critical for the uptake and degradation of infectious agents and senescent cells, and it participates in development, tissue remodeling, the immune response, and inflammation.

\subsubsection{MECHANISM OF PHAGOCYTOSIS}

Particle internalization is initiated by the interaction of specific receptors on the surface of the phagocyte with ligands on the surface of the target. This leads to the polymerization of actin at the site of ingestion, and the internalization of the target via an actin-based mechanism ${ }^{29}$. After internalization actin is shed from the phagosome, and the phagosome matures by a series of fusion and fission events with components of the endocytic pathway, culminating in the formation of the mature phagolysosome ${ }^{30.31}$. Since endosome-lysosome trafficking occurs primarily in association with microtubules, phagosome maturation requires the coordinated interaction of the actin and tubulin based cytoskeletons. 
The signals required for uptake of particles and the arrangement of the cytoskeletal proteins vary depending upon which phagocylic receptor is engaged. Different receptors are involved in phagocytosis such as. Fo receptormediated phagocytosis, complement receptor-mediated phagocytosis, mannose receptor-mediated phagocytosis and PS receptor-mediated phagocytosis. Here, I will focus on the clearance of apoptotic cells and the irvolvement of PS and the PS receptor.

\subsubsection{MEMBRANE ALTERATIONS ESSENTIAL FOR THE CLEARANCE OF APOPTOTIC CELLS}

An extensive number of cells are contimuously undergoing apoptosis in tissues of higher organisms. These dying cells are rarely observed in vivo due to their efficient engulfment and degradation by phagocytic cells such as macrophages $^{32}$. Since phagocytosis of apoptotic cells is a normal, ongoing process, the mechanisms enabling macrophages to recognize, bind, internalize, and degrade apoptotic cells need to function without activating the proinflammatory responses ${ }^{33 .}{ }^{34}$. In order to phagocytose an apoptotic cell, receptors on the macrophage must recognize a ligand or a combination of ligands on apoptotic cells that are not present on viable cells (Figure 2).

\section{SURFACE CHANGES ON APOPTOTIC CELLS LEADING TO RECOGNITION AND REMOVAL}

The structures that are recognized on the apoptotic cell are poorly characterized. Currently, the best characterized "eat me" signal at the surface of the apoptotic cell is PS ${ }^{35}$. PS is recognized by the phagocyte either directly with the PS receptor ${ }^{36}$ or indirectly through several bridging molecules that link the phagocyte receptors to PS on the apoptotic cell. Recently, it was discovered that MFG-E8 bridges apoptotic cells via PS to the $\alpha_{4} \beta_{3}$ vitronectin receptor of the phagocyte, stimulating the uptake of apoptotic cells ${ }^{37}$. The $\beta_{2}$-glycoprotein- 1 receptor is linked via $\beta_{2}$-glycoprotein-1 to $\mathrm{PS}^{38}$. The product of growth arrested specific gene 6 (Gas-6) has been shown to specifically bind to PS and stimulate phagocytosis of apoptotic cells through the Mer receptor tyrosine kinase ${ }^{39}$. Inter cellular adhesion molecule 3 (ICAM-3) is exposed by apoptotic cells and promotes their uptake ${ }^{40}$. Another class of surface changes that has been implied in apoptotic cell removal involves lectin-type interactions with carbohydrate structures exposed at the surface of the dying cell. For example, members of the family of defense collagens ${ }^{41}$, which include the C-type lectins known as Collectins as well as the first component of the classical complement 
pathway, C1q, have been shown to bind to apoptotic cells $\mathrm{s}^{42-44}$ and drive ingestion through interaction with calreticulin and CD91 on the phagocyte in vitro $^{45}$. Capping of $\mathrm{CD} 43$, a mucin-like major sialoglycoprotein containing sialylpolylactosaminyl chains present on the surface of apoptotic cells, is responsible for the early recognition by macrophages ${ }^{46,47}$.

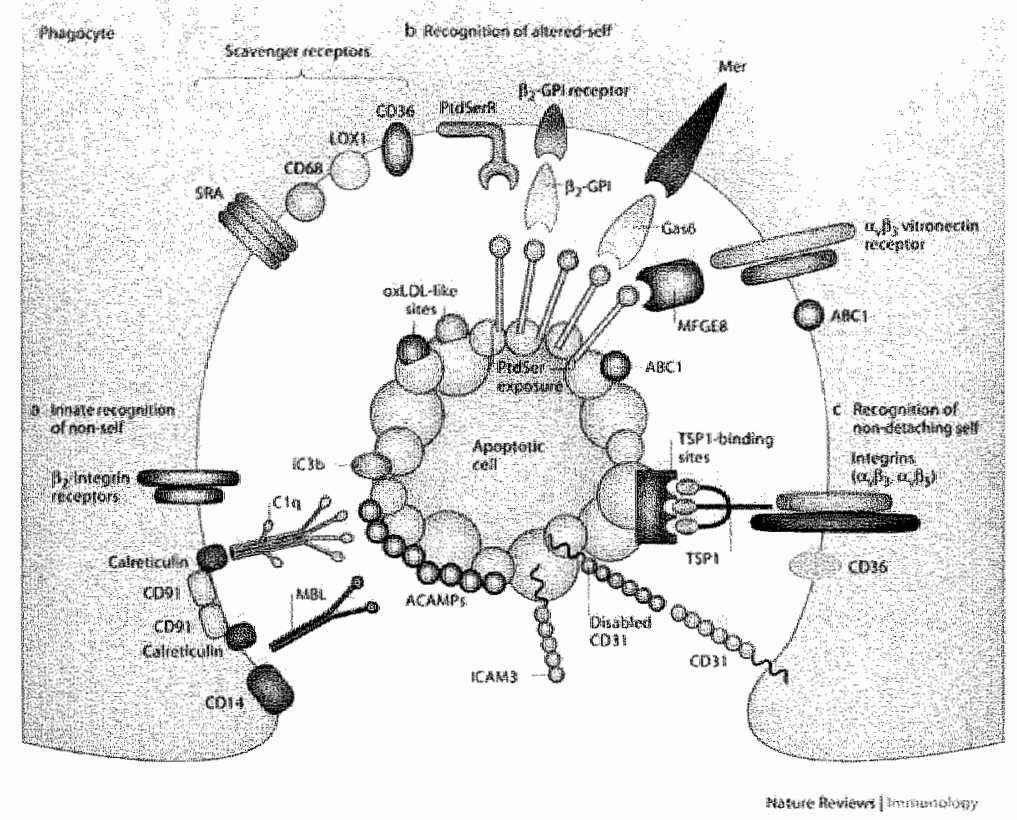

Figure 2 Recognition and clearance markers on apoptotic cells and phagocytes (Reproduced with permission from Nature Reviews Immunology (Savill ef al. 2002) ${ }^{61}$ copyright (2002) Macmillan Magazines Ltd.

Interestingly, studies have indicated that the various surface changes on apoptotic cells are probably expressed simultaneously, but that the mechanism utilized to clear these death cells is determined by the type of phagocyte or the phagocyte activation status. It has been described by Schlegel et al. that PS is not only expressed on the apoptotic cell but also on the surface of activated macrophages which implies a dual role for PS: one on the phagocyte and another on the apoptotic cell ${ }^{48}$. The ATP-binding site transporter ABC-1 appears to be involved in the translocation of phospholipids in both the apoptotic cell and the phagocyte ${ }^{49}$. However, its role in the translocation of PS remains controversial. 


\section{RECEPTORS IMPLICATED IN THE RECOGNITION AND CLEARANCE OF APOPTOTIC CELLS}

Phagocytes are particularly talented in the recognition and subsequent engulfment of apoptotic cells via various receptors. Apoptotic cell recognition receptors can be divided into two categories, those involved in tethering of apoptotic cells versus those triggering their uptake. The phosphatidy/serine receptor (PSR) on the phagocyte is thought to play a critical role in stimulating the uptake of apoptotic cells, while the other receptors are supposed to be responsible for tethering the apoptotic cell to the phagocyte ${ }^{50}$. The majority of these receptors are well known proteins such as integrins of the $\alpha_{4} \beta_{3}$ or $\alpha_{4} \beta_{5}$ classes and the scavenger receptors of the $A$ and $B$ classes. It has also been reported that the LPS receptor CD14 is involved in the tethering of apoptotic lymphocytes via interaction with ICAM3 moieties on the apoptotic cell ${ }^{51}$. CD36, which is part of a thrombospondin-mediated pathway, bridges the dying cell and the phagocyte by binding a putative thrombospondin receptor and the CD36Vitronectin $\alpha_{v} \beta_{3}$ complex, respectively. Furthermore, receptors on the phagocyte that are particularly implicated in the recognition of PS, include the lectin-like oxidized low-density lipoprotein receptor-1 (LOX-1), the $\beta_{2}$-glycoprotein I $\left(\beta_{2} \mathrm{GPI}\right)$ receptor, the $\alpha_{v} \beta_{3}$ vitronectin receptor, the Mer receptor tyrosine kinase, and the PSR. The PSR appears to be very important in the clearance of apoptotic cells in the lung and brain since PSR-deficient mice accumulated dead cells in the lung and brain ${ }^{52}$. Recently, another report of a knockout of the PSR gene revealed that the PSR receptor has essential functions during embryogenesis but not in apoptotic cell removall ${ }^{53}$. The phenotypes of the knockout mice lacking the PSR receptor; as well as the location of the protein within cells ${ }^{54,55}$, cast doubt on the assignment of this protein as the PSR receptor $^{56}$. The class $B$ scavenger receptor type I (SR-BI) is responsible for the PS-mediated phagocytosis by testicular Sertoli cells.

\subsubsection{CONSEQUENCES OF THE CLEARANCE OF APOPTOTIC CELLS BY PHAGOCYTES}

A ballance between pro- and anti-inflammatory mediators is critical in preventing the innate immune response from becoming destructive to the host and in promoting resolution of inflammation. Whether phagocytosis of apoptotic cells is accompanied by the elaboration of anti-inflammatory or pro-inflammatory mediators might depend on the activation state and on the type of the phagocyte. Monocytes and macrophages differentially alter their cytokine profile 
in the presence of apoptotic neutrophils and apoptotic lymphocytes. Phagocytosis of apoptotic neutrophils by LPS-stimulated human monocytederived macrophages actively inhibits the production of IL-1 $\beta, T N F-\alpha$, and IL-10 through the induction of TGF- $\beta^{57-60}$. Voll et al., however, showed that phagocytosis of apoptotic lymphocytes by LPS-stimulated macrophages increased the secretion of the anti-inflammatory and immunoregulatory cytokine $\mathrm{IL}-10^{61}, 62$. They suggested that the increase in IL-10 could result in immunosuppression in conditions associated with increased apoptosis, including cancer, exposure to radiation, pregnancy, and viral infections such as $H_{I V}{ }^{63}$. The release of TGF- $\beta$ by macrophages is regulated by recognition of PS exposed on apoptotic cells, and results in accelerated resolution of inflammation ${ }^{64}$. Reduced TGF- $\beta$ activity is considered to be responsible for development of autoimmune disorders, such as systemic lupus erythematosus. Recently, it was shown that tissue transglutaminase 2 is required for proper phagocytosis of apoptotic cells ${ }^{65}$.

In summary, the uptake of apoptotic cells not only inhibits pro-inflammatory cytokine production, but induces the macrophage to become anti-inflammatory by engagement of the PSR. Therefore, PS-exposing membranes are supposed to play a major role in the induction of the anti-inflammatory response ${ }^{66}$. However, the exact mechanisms by which apoptotic cells induce this response are still not known.

\subsubsection{DISEASES ASSOCIATED WITH IMPAIRED PHAGOCYTIC CLEARANCE}

Deficiencies in apoptotic cell clearance may contribute to the pathogenesis of both systemic and organ-specific autoimmune diseases. During apoptosis potential auto-antigens are relocated and altered and may become the target of immune recognition, especially if the dying cells are not rapidly engulfed and destroyed by neighboring cells or professional phagocytes, such as macrophages and dendritic cells. Rosen and Casiola-Rosen showed that impaired recognition and/or clearance of apoptotic cells contribute to inflammatory and autoimmune diseases ${ }^{67}$. Recently, Asano et al. showed that masking PS inhibits apoptotic cell clearance and induces auto-antibody production in mice ${ }^{68}$. In line with this, systemic lupus erythematosus patients show an impaired clearance of apoptotic cells ${ }^{69}, 70$. Defective apoptotic cell clearance has also been observed in the pathogenesis of chronic airway inflammatory disease, like cystic fibrosis. Another observation of impaired clearance of apoptotic cells was found in atherosclerotic lesions, possibly due to 
the presence of ox-LDL, which selectively delays the engulfment of apoptotic cells, which may contribute to chronic persisting inflammation ${ }^{79}$.

Taken together, the uptake of apoptotic cells by macrophages is an important step in the resolution of inflammation. The mechanisms underlying the phagocytosis of apoptotic cells are well defined but more studies are needed to define a clear link between impaired phagocytosis of apoptotic cells and the pathogenesis of diseases. In this regard, in vivo models, in which a deficiency in the clearance of apoptotic cells is present " are useful to study the consequences of inadequate phagocytosis of dying cells and are essential to facilitate the development of new therapeutic strategies for autoimmune and inflammatory diseases.

\subsection{APOPTOSIS AND THROMBOSIS}

Thrombosis is amongst the major debilitating and life-threatening disease of the Western world. The novel understanding that apoptotic cells can contribute to thrombotic and haemostatic processes gained scientific interest. Apoptotic cells are characterized by the exposure of PS in the outer membrane leaflet, thereby providing a catalytic surface on which coagulation reactions can take place. Assemblage of the coagulation factors to this catalytic membrane surface culminates in the formation of thrombin. Shielding of PS with annexin A5 inhibits thrombin formation, indicating that PS exposure on the cell membrane surface is essential for thrombin formation. The relation between thrombogenicity and apoptosis was extensively studied and revealed a significant correlation between thrombin formation and the degree of apoptosis.

Apoptosis is involved in many pathophysiological processes, like atherosclerosis, inflammation and wound healing, which are all associated with an increased risk of thrombosis. For example, enhanced procoagulant activities associated with PS exposure have been observed in apoptotic vascular smooth muscle cells ${ }^{72},{ }^{73}$, endothellal cells, HeLa cells ${ }^{74}$, lymphocytes ${ }^{10,} 75$ and atheroscleratic plaques ${ }^{76}, 77$. More recently, apoptotic tumor cells were also found to be thrombogenic ${ }^{78}$. 


\section{ANNEXINS}

The annexins are a family of proteins that share structural and functional features. The annexins are characterized structurally by the presence of canonically repeated domains each of which contains a conserved amino acid matif, the endonexin $100 \mathrm{p}^{79}$. The annexins share the functionality to bind to negatively charged phospholipids in a calcium-dependent manner ${ }^{80}$. Their physiological relevance is still poorly understood, but is thought to involve phospholipid membrane-associated processes. Annexin A5 is the best known member of the annexin family, not only because its gene and protein structure (primary, secondary and tertiary) have been elucidated but also because it is widely used to study apoptosis in vitro and in vivo in animal models and patients $^{81-86}$. Annexin A5 binds with high affinity and selectivity to phosphatidylserine (PS), which is exposed at the surface of apoptotic cells. In spite of the wealth of experimental studies, the exact role of annexin A5 remains poorly understood.

\subsection{ANNEXIN A5}

Annexin A5 was originally discovered as an anticoagulant protei ${ }^{87}$ with an antithrombotic activity in vivo ${ }^{88}$. This anticoagulant activity is due to its high affinity binding to PS.

\subsubsection{STRUCTURE OF THE ANNEXIN A5 GENE AND PROTEIN}

The annexin A5 gene is located on chromosome 4q26-28 and comprises an untranslated exon 1 plus 12 coding exons, which span a region of approximately $29 \mathrm{~kb}^{89}$. The annexin A5 gene contains a $5^{\prime}$ promoter region of $1200 \mathrm{bp}$ and a $3^{\prime}$ downstream region containing a poly-adenylation site. The absence of a typical TATA box and the presence of GC-rich regions containing putative Sp1-binding sites in the promoter characterize the gene as a "housekeeping" gene, of which the expression levels are actively regulated and differ between different types of cells ${ }^{90,91}$. The existence of an alternative promoter further suggests that transcription of the annexin A5 gene is tightly controlled $^{92}$. Comparative and evolutionary studies of the annexin A5 gene have revealed that this gene is highly conserved among and between species ${ }^{93}$. The regions and extents of sequence conservation in the annexin $A 5$ gene between 
various species likely reflect the importance of these regions in structure, function and regulation of this gene ${ }^{94,85}$.

Annexin A5 has been a model for investigation of the structure and function of the annexin family. Human annexin A5 is an unglycosylated protein of 319 amino acids with a molecular weight of $35.8 \mathrm{kDa}$ and a pl of approximately 4.7 . The primary structure of annexin A5 is characterized by the presence of an $\mathrm{N}$ terminal tail, which is unique for each annexin, and a C-terminal core, which consists of four homologous domains of 65-70 amino acids. The four domains are related via two types of pseudo two-fold symmetry axes: one central axis relating the modules formed by domain I-IV and II-III and two local axes relating I and IV, and II and III, respectively (Figure 3a). Each domain contains $5 \alpha-$ hellices (A-E) wound into right-handed superhelixes which are connected via loops (Figure $3 b$ ). Helices $A, B, D$ and $E$ form an anti-parallel bundle to which helix $C$ lies perpendicular. The four domains are arranged in a cyclic array, giving the molecule a slightly curved shape with a convex and a concave face ${ }^{96}$ (Figure $3 \mathrm{c}$ ). The calcium-binding sites are located at the convex, membranefacing side of the protein, while the $\mathrm{N}$ and $\mathrm{C}$-termini lie on the concave side ${ }^{97}$. In the presence of calcium-ions annexin $A 5$ binds to phosphatidylserine containing membranes with an affinity constant of more than $10^{9} \mathrm{M}^{-198}$. Bound anmexin A5 dissociates from the membrane if the calcium-ions are removed by chelation with EDTA ${ }^{99}$.

Annexin A5 contains one cysteine residue, located in the fourth domain and bears a single tryptophan residue (Trp-187) located in the third domain which is involved in membrane binding. Binding of calcium induces a large scale conformational transition of domain III. The unique tryptophan in the IIIA-IIIB loop moves from a buried position in the absence of calcium ("closed' A form) to the surface when calcium is bound ("open' B form) ${ }^{59}$. Recently, Brisson et al. showed by atomic force microscopy and cryo-electron microscopy guided by $\mathrm{X}$ ray crystallographic data that annexin $A 5$ binds to the phospholipid surface with its convex side, without changing significantly the annexin fold of its soluble form. Analysis of the phospholipid-binding property of annexin A5 point towards an extrinsic nature. However, at a $\mathrm{pH}$ close to its $\mathrm{pl}$ annexin $\mathrm{A} 5$ can become intrinsically bound ${ }^{100}$. Atomic force and cryo-electron microscopic studies revealed that annexin $A 5$ molecules in solution are monomers, but upon binding to a phospholipid surface annexin A5 will form trimers that self-assemble into two-dimensional crystals (with $\mathrm{p} 3$ and p6 symmetry) by protein-protein interactions $^{101 .}{ }^{102}$ (Figure $3 \mathrm{~d}$ ). Trimer formation and two-dimensional crystallization of the trimers on the surface have also been observed for annexin 
$\mathrm{A} 4^{103}, \mathrm{~A} 6^{104}$ and $\mathrm{A} 12^{105}$. This two-dimensional crystallization on the membrane surface appears to be a general property of the annexins and likely underlies their biological activities.

a)

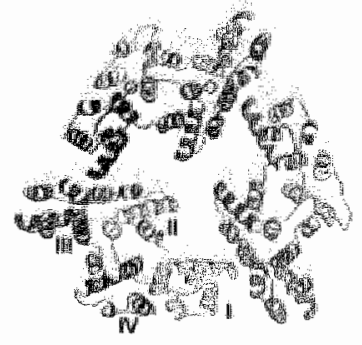

b)

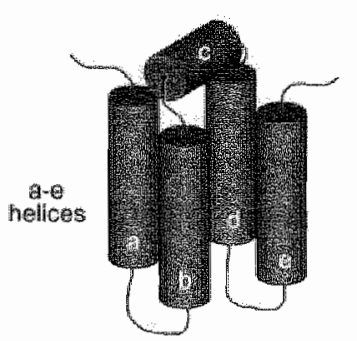

c)

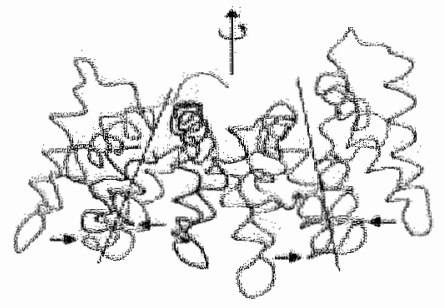

d)

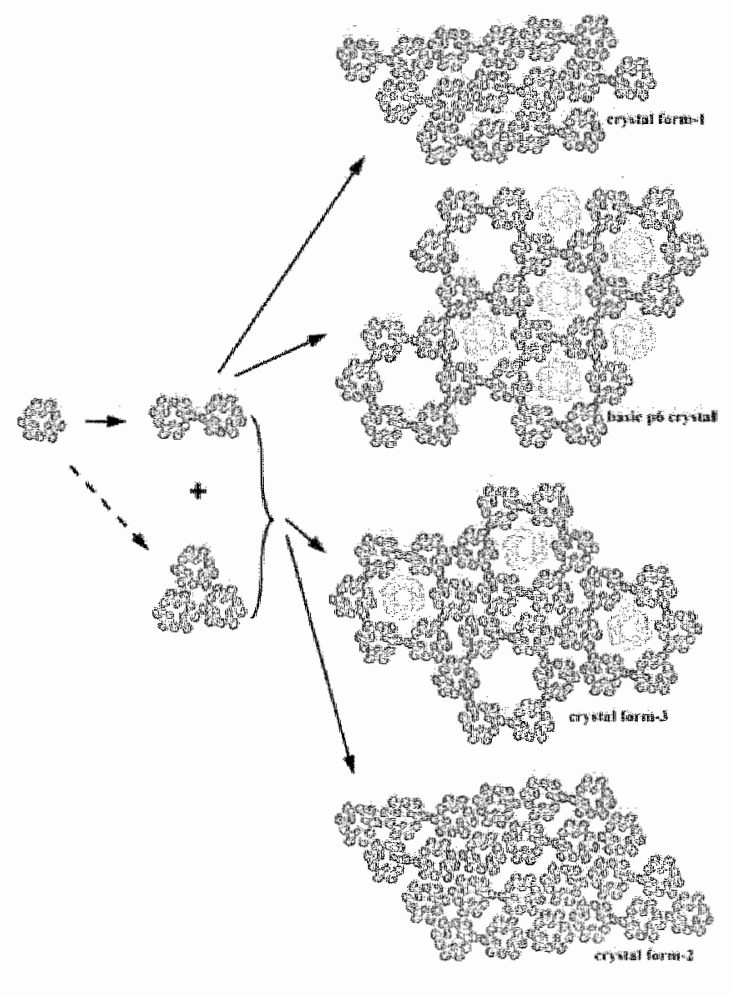

Figure 3 Two-dimensional structure of annexin A5. (a) trimer of annexin A5; (b) single annexin A5 domain with awe helices; (c) side view of an annexin A5 molecule showing a slightly curved shape, the arrows indicate the positions of the calcium binding residues located in the D-E loop of each domain; (d) mechanistic model of the four two dimensional crystal forms. Reproduced with permission from Elsevier (Oling et al. 2000, 2001) ${ }^{\text {t01. 141. }}$.

\subsubsection{BIOLOGICAL ACTIVITIES OF ANNEXIN A5}

Annexin A5 has been studied extensively to elucidate its biological activities. Most of these activities are related to the phospholipid-binding property of annexin $\mathrm{A} 5$ and are believed to form the basis for its physiological function. In 
the past two decades, a variety of biological activities have been reported. Annexin A5 inhibits blood coagulation through its high-affinity binding to PS ${ }^{37}$. ${ }^{106-108}$. In addition, it has been shown that annexin A5 regulates inflammation by inhibiting phospholipase $A_{2}$ activity through depletion of the phospholipid substrate ${ }^{109}$. Moreover, a specific interaction of annexin A5 with histones may indicate a role for annexin $A 5$ in gene regulation. Furthermore, annexin $A 5$ is thought to play a role in signal transduction through the inhibition of protein kinase $C$ (PKC)-mediated phosphorylation ${ }^{110}$. The inhibition occurs by direct interaction with PKC. Annexin A5 may also play a role in cell-matrix interactions because it binds to glycosaminoglycans (GAG) ${ }^{111-113}$ and is a potential receptor for collagen type $11^{114}, 115$. Later, its capacity to act as a collagen-regulated calcium channel in the membranes of chondrocytes and matrix vesicles, which are produced by these cells during their differentiation prior to the onset of calcification, was recognized and investigated in great deta: ${ }^{97,} 116-118$. Whether annexin A5 functions in a signaling pathway that leads to the activation of a calcium entry channel, or forms a calcium channel itself is still unknown. Since annexin $\mathrm{A5}$ does not penetrate into phospholipid bilayers at neutral $\mathrm{pH}$ it is unlikely that annexin $\mathrm{A5}$ alone is responsible for calcium transport across the membrane. But, at a slightly acidic $\mathrm{pH}$ annexin $\mathrm{A} 5$ is able to insert into the bilayer ${ }^{100}$ and mediate a peroxide-induced $\mathrm{Ca}^{2+}$ influx ${ }^{118}$. Recent studies have shown that annexin A5 plays a role in hepatitis $B$ infection ${ }^{120}$ and influenza virus infection ${ }^{121}$. Annexin A5 serves as a bridging molecule between the virus and the target cell by binding to specific surface antigens present on the viral envelope and to PS on the target cell, respectively.

Annexin A5 is considered to be predominantly an intracellular protein since it lacks a signal sequence. However, it has been reported that annexin A5 is also located extracellularly, suggesting that it might be secreted by a still unknown and selective mechanism ${ }^{122}$. The true physiological function depends clearly on whether annexin A5 is located intra- or extra-cellularly.

Despite the variety of biological activities, the physiological relevance of annexin A5 remains to be established. Recently, Brachvogel et al. developed an annexin A5-deficient mouse and showed that the annexin A5 gene is specifically and sequentially expressed in skeletal elements and in the vascular system during embryogenesis ${ }^{91}$. Surprisingly, the annexin A5-deficient mice are viable, fertile and reveal no significant metabolic and functional defects, suggesting a compensatory effect of other members from the annexin family due to their high structural and functional similarity ${ }^{123}$. 
In spite of the uncertainty of the physiological relevance of annexin $A 5$, a new class of diseases related to annexin dysfunction has recently been defined, called the "Annexinophaties"

\subsubsection{ANNEXINOPATHIES}

ANTI-PHOSPHOLIPID ANTIBODY SYNDROME (APS) AND SYSTEMIC LUPUS ERYTHEMATOSIS (SLE)

APS and SLE are acquired autoimmune disorders associated with vascular thrombosis, embolism and recurrent pregnancy losses. Elevated levels of antiphospholipid antibodies have been observed in these patients. Rand et al. showed that anti-phospholipid antibodies potentially displace endogenous annexin $A 5$ from placental villi ${ }^{125}$. On basis of this observation it has been hypothesized, that the lack of annexin A5 on placental villi, due to antiphospholipid antibodies, is responsible for thrombosis and pregnancy loss in patients with anti-phospholipid antibody syndrome (APS) ${ }^{126}$. It has been suggested, that interference of anti-annexin A5 antibodies with the annexin A5 shield on the placental villi leads to the exposure of anionic procoagulant phospholipids ${ }^{127}$. This may be an important contributory factor to thrombosis and recurrent loss of pregnancy in APS. Anti-annexin A5 antibodies have been described to be highly specific for APS and elevated levels of antibodies are detected in patients with systemic lupus diseases (SLE) ${ }^{128}$. Anti-annexin A5 antibodies are suggested to be a significant risk factor for recurrent miscarriages in SLE patients. Furthermore, it has been suggested that antiannexin $A 5$ auto-antibodies may influence the clinicall course of rheumatoid arthritis since the concentration of anti-annexin A5 antibodies was significantly raised in sera from patients with rheumatoid arthritis ${ }^{129}$. However, van Heerde et al. found no correlation between the presence of anti-phospholipid antibodies and a history of thromboembolic complications ${ }^{130}$. Based on these observations, they conclude that displacement of annexin A5 from cellular surfaces by antiphospholipid antibodies is not a common mechanism in patients with antiphospholipid antibodies.

\section{MYOCARDIAL INFARCTION}

Myocardial infarction is one of the clinical complications of atherosclerosis, which is a chronic process starting early in life and progressing through the years. High levels of procoagulant microparticles are present in the circulating blood of patients with acute coronary syndrome and in human atherosclerotic 
plaques and may participate in the generation of thrombi ${ }^{76,77}$. Moreover, low levels of annexin A5 have been reported in young patients suffering from myocardial infarction, which may be indicative for a prothrombotic condition ${ }^{134}$, 132. More studies are needed to assess the value of this potential "annexinopathy", and its clinical importance.

\section{PRE-ECLAMPSIA}

Pre-eclampsia continues to be a challenging syndrome in pregnancy. Defective placentation is an important common pathological mechanism in pre-eclampsia. During pregnancy, annexin A5 levels are strongly elevated, suggesting that annexin A5 plays a key role in placentation and placental integrity ${ }^{133}$. It is present in high concentrations on placental trophoblasts and is thought to maintain the blood fluidity on the constantly regenerating surfaces of the trophoblasts at the maternofetal tissue junction. In the placentae of preeclamptic women reduced levels of annexin A5 have been observed ${ }^{134}$. The circulating plasma levels of annexin A5 are not significantly increased in pregnancies complicated by pre-eclampsia ${ }^{135}$.

Further research into the physiological function of annexin A5 will reveal additional "annexinopathies".

\subsection{IMAGING OF APOPTOSIS WITH ANNEXIN A5}

In 1992, Fadok et al. set the scene for a novel apoptosis detection method ${ }^{10}$. A combination of her finding, that apoptotic cells express PS at their cell surface, and the insight into the physiochemical properties of annexin A5 led to the discovery by $\mathrm{C}$. Reutelingsperger that annexin $\mathrm{A} 5$ is an excellent tool to detect apoptotic cells ${ }^{136,137}$. This discovery forms the basis of the development of novel procedures to detect apoptosis using annexin A5. Nowadays, annexin A5 is used worldwide as a valuable probe to detect apoptotic cells in vitro as well as in wivo. Initially, van den Eijnde and co-workers were able to detect apoptosis in the developing embryo by direct injection of biotinylated annexin A5 in the heart ${ }^{138}$. Recently, biotinylated annexin A5 was used to detect myocardial cell death in an ischemic and reperfusion model of the mouse heart in vivo ${ }^{81}$. Until recently, in vivo detection and dynamics of apoptosis was impossible or limited to a static picture via techniques such as harvesting the tissue and subsequent histological analysis. Fluorescently or technetium labeled annexin A5 provided a novel method for real-time imaging of apoptosis in living organisms. Fluorescently labeled annexin A5 made it possible to study the kinetics of 
myocardial cell death at single cell level ${ }^{82}$. Technetium labeled annexin A5, on the other hand was used to detect apoptosis non-invasively in animal model ${ }^{86}$ and in patients with acute myocardial infarction ${ }^{83}$, in patients with an intracardiac tumor $^{34}$ and in patients with heart transplant rejection ${ }^{139}$. Recently, annexin A5 was shown to be a valuable marker to distinguish between a stable and instable plaque since a substantial amount of apoptosis was found in unstable plaques ${ }^{140}$.

\section{AIM OF THIS THESIS}

The main aim of this thesis was two-fold: 1) to obtain more insight in the physiological significance of annexin A5 by a genetic approach and 2) to study the role of annexin A5 in cell membrane biology during apoptosis.

Screening the annexin A5 gene for mutations in patients with venous thrombosis and myocardial infarction revealed several mutations, one of which (the C-1T mutation) was associated with a slight increased risk of myocardial infarction. These results show that there exists a relationship between annexin A5 and arterial thrombosis.

Next, we investigated the relationship between the point of no return in the cell death program and the externalization of PS. These data revealed that cardiomyocytes can recover from the initiation of apoptosis, if reperfusion is restored rapidly enough. Another observation was that the cardiomyocytes, which were triggered by a short ischemic episode, bound and internalized annexin A5. Further, in vitro studies showed that annexin A5 binding to PS mediates a novel pinocytic pathway. This novel pathway may provide an attractive means to deliver drugs to tissues containing apoptotic cells, such as tumors. Finally, we found that neither shielding of PS, which acts as a trigger for uptake of apoptotic cells by macrophages nor the inhibition of apoptotic body formation is sufficient to inhibit phagocytosis. Together with our previous observations, we hypothesize that annexin A5 downregulates surface receptors and/or proteins necessary for recognition and subsequent uptake by macrophages. 


\section{REFERENCES}

1. Kerr JF, Wyllie AH, Currie AR, Apoptosis: a basic biological phenomenon with wide-ranging implications in tissue kinetics. Br J Cancer, 1972; 26: 239-257.

2. Rosse $T$, Olivier R, Monney L, Rager $M$, Conus $S$, Fellay I, Jansen $B$, Borner $C_{\text {, }}$ $\mathrm{Bcl}-2$ prolongs cell survival after Bax-induced release of cytochrome c. Nature. 1998; 391: 496-499.

3. Hengartner MO, The biochemistry of apoptosis. Nature, 2000; 407: 770-776.

4. Jacobson MD, Weil M, Raff MC, Programmed cell death in animal development. Cell, 1997: 88: $347-354$.

5. Kerr JF, Winterford CM, Harmon BV, Apoptosis. Its significance in cancer and cancer therapy. Cancer, 1994; 73: 2013-2026.

6. McLaughlin R, Kelly CJ, Kay E, Bouchier-Hayes D, The role of apoptotic cell death in cardiovascular disease. Ir J Med Sci, 2001; 170: 132-140.

7. Mattson MP, Camandola $S$, NF-kappaB in neuronal plasticity and neurodegenerative disorders. J Clin Invest, 2001; 107: 247-254.

8. Leist $M$, Jaattela $M$, Four deaths and a funeral: from caspases to alternative mechanisms. Nat Rev Mol Cell Biol, 2001; 2: 589-598.

9. Zwaal RF, Schroit AJ, Pathophysiologic implications of membrane phospholipid asymmetry in blood cells. Blood, 1997; 89: 1121-1132.

10. Fadok VA, Voelker DR, Campbell PA, Cohen JJ, Bratton DL, Henson PM, Exposure of phosphatidylserine on the surface of apoptotic lymphocytes triggers specific recognition and removal by macrophages. I Immunol, 1992; 148: 22072216.

11. Bratton DL, Fadok VA, Richter DA, Kailey JM, Guthrie LA Henson PM, Appearance of phosphatidylserine on apoptotic cells requires calcium-mediated nonspecific flip-flop and is enhanced by loss of the aminophospholipid translocase. $J$ Biol Chem, 1997; 272: 26159-26165.

12. Verhoven B, Schlegel RA, Williamson $P$, Mechanisms of phosphatidylserine exposure, a phagocyte recognition signal, on apoptotic T lymphocytes. I Exp Med, 1995; 182: 1597-1601

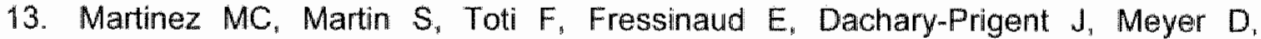
Freyssinet $\mathrm{JM}_{\mathrm{B}}$. Significance of capacitative Ca2* entry in the regulation of phosphatidylserine expression at the surface of stimulated cells. Biochemistry, 1999; 38: 10092-10098.

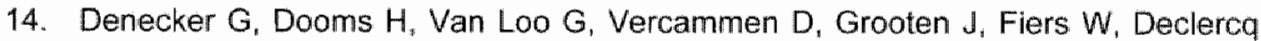
$W$, Vandenabeele $P$, Phosphatidyl serine exposure during apoptosis precedes release of cytochrome $c$ and decrease in mitochondrial transmembrane potential. FEBS Lett, 2000; 465: 47-52.

15. Verhoven $B$, Krahling $S$, Schlegell RA, Williamson $P$, Regulation of phosphatidylserine exposure and phagocytosis of apoptotic T lymphocytes. Cell Death Differ, 1999; 6: 262-270.

16. Dillon SR, Constantinescu $A$, Schlissel MS, Annexin $V$ binds to positively selected B cells. J Immunol, 2001; 166: 58-71.

17. Sessions $A_{1}$ Horwitz AF, Differentiation-related differences in the plasma membrane phospholipid asymmetry of myogenic and fibrogenic cells. Biochim Biophys Acta, 1983; 728: 103-111. 


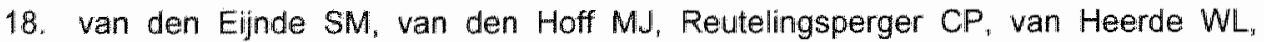
Henfling ME, Vermeij-Keers $C$, Schutte $B$ "Borgers $M$, Ramaekers FC, Transient expression of phosphatidylserine at cell-cell contact areas is required for myotube formation. $J$ Cell Sci, $2001 ; 114: 3631-3642$.

19. Adler RR, Ng AK, Rote NS, Monoclonal antiphosphatidylserine antibody inhibits intercellular fusion of the choriocarcinoma line. UAR. Biol Reprod, 1995; 53: 905910.

20. Shi $J$, Gilbert GE, Kokubo $Y$, Ohashi $T$, Role of the liver in regulating numbers of circulating neutrophils. Blood $2001 ; 98: 1226-1230$.

21. Kuijpers TW, Maianski NA, Tooll AT, Becker $K_{n}$ Plecko $B$, Valianpour $F$, Wanders RJ, Pereira R, Van Hove J, Verhoeven AJ, Roos D, Baas F, Barth PG, Neutrophils in Barth Syndrome (BTHS) avidly bind Annexin- $V$ in the absence of apoptosis. Blood, 2004.

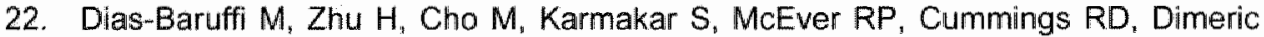
galectim-1 induces surface exposure of phosphatidylserine and phagocytic recognition of leukocytes without inducing apoptosis. I Biol Chem, 2003; 278: $41282-41293$.

23. Callahan MK, Halleck MS, Krahling $S$, Henderson AJ, Williamson $P$, Sichlegel RA, Phosphatidylserine expression and phagocytosis of apoptotic thymocytes during differentiation of monocytic cells. J Leukoc Biol, 2003; 74: 846-856.

24. Goth SR, Stephens RS, Rapid, transient phosphatidylserine externalization induced in host cells by infection with Chlamydia spp. Infect Immun, 2001; 69: 1109-1119.

25. Bevers EM, Comfurius $P$, Zwaal RF, Changes in membrane phospholipid distribution during platelet activation. Biochim Biophys Acta, 1983; 736: 57-66.

26. Lentz $B R_{n}$ Exposure of platelet membrane phosphatidylserine regulates blood coagulation. Prog Lipid Res, 2003; 42: 423-438.

27. Heemskerk JW, Bevers EM, Lindhout T, Platelet activation and blood coagulation. Thromb Haemost, 2002; 88: 186-193.

28. Thiagarajan $P$, Tait $J F$, Binding of annexin V/placental anticoagulant protein $I$ to platelets. Evidence for phosphatidylserine exposure in the procoagulant response of activated platelets. $J$ Biol Chem, 1990; 265: 17420-17423.

29. Greenberg S, Signal transduction of phagocytosis. Trends Cell Biol 1995; 5: 93-99.

30. Beron $W$, Alvarez-Dominguez $C$, Mayorga $L$, Stahl PD, Membrane trafficking along the phagocytic pathway. Trends Cell Biol, 1995; 5: 100-104.

31. Desjardins M, Biogenesis of phagolysosomes: the 'kiss and run' hypothesis. Trends Cell Biol, 1995; 5: 183-186.

32. Savill $\mathrm{d}$ Recognition and phagocytosis of cells undergoing apoptosis. Br Med Bull, $1997 ; 53 ; 491-508$.

33. Savill J, Apoptosis. Phagocytic docking without shocking. Nature, 1998; 392: 442443.

34. Platt $N$, da Silva RP, Gordon $S$, Recognizing death: the phagocytosis of apoptotic cells. Trends Cell Biol, 1998; 8: 365-372.

35. Krahling $S$, Callahan $M K$, Williamson $P$, Schlegel RA, Exposure of phosphatidylserine is a general feature in the phagocytosis of apoptotic lymphocytes by macrophages. Cell Death Differ, 1999; 6: 183-189.

36. Fadok VA, Bratton DL, Rose DM, Pearson A, Ezekewitz RA, Henson PM, A receptor for phosphatidylserine-specific clearance of apoptotic cells. Nature, 2000; 405: 85-90. 
37. Hanayama $R$, Tanaka $M$, Miwa $K$, Shinohara $A$, Iwamatsu $A$, Nagata $S$, Identification of a factor that links apoptotic cells to phagocytes. Nature, $2002 ; 417$ : 182-187.

38. Balasubramanian $K$, Chandra $J$, Schroit $A J$ Immune clearance of phosphatidylserine-expressing cells by phagocytes. The role of beta2-glycoprotein I in macrophage recognition. I Biol Chem, 1997; 272: 31113-31117.

39. Scott RS, McMahon EJ, Pop SM, Reap EA, Caricchio $\mathbb{R}_{\mathrm{n}}$ Cohen PL, Earp $H S$, Matsushima GK, Phagocytosis and clearance of apoptotic cells is mediated by MER. Nature, 2001; 411: 207-211.

40. Moffatt $O D$, Devitt $A$, Bell ED, Simmons DL, Gregory $C D_{1}$ Macrophage recognition of ICAM-3 on apoptotic leukocytes. J Immunol, 1999; 162: 6800-6810.

41. Tenner AJ, Membrane receptors for soluble defense collagens. Curr Opin Immunol, 1999; 11: 34-41.

42. Korb LC, Ahearn JM, C1q binds directly and specifically to surface blebs of apoptotic human keratinocytes: complement deficiency and systemic lupus erythematosus revisited. J Immunol, 1997; 158: 4525-4528.

43. Navratil JS, Watkins SC. Wisnieski JJ, Ahearn JM. The globular heads of C19 specifically recognize surface blebs of apoptotic vascular endothelial cells. J Immunol, 2001; 166:3231-3239.

44. Ogden CA, deCathelineau A, Hoffmann PR, Bratton D, Ghebrehiwet B, Fadok VA, Henson $P M_{*}, C 1 q$ and mannose binding lectin engagement of cell surface calreticulin and CD91 initiates macropinocytosis and uptake of apoptotic cells. I Exp Med, 2001; 194: 781-795.

45. Vandivier RW, Ogden CA, Fadok VA, Hoffmann PR, Brown KK, Botto M, Walport $M J$, Fisher $\mathrm{JH}$, Henson $\mathrm{PM}_{0}$ Greene $K E$, Role of surfactant proteins $A, D$, and $C 1 \mathrm{q}$ in the clearance of apoptotic cells in vivo and in vitro: calreticulin and CD91 as a common collectin receptor complex. J Immunol, 2002; 169: 3978-3986.

46. Eda $S$, Yamanaka $M$, Beppu M, Carbohydrate-mediated phagocytic recognition of early apoptotic cells undergoing transient capping of CD43 glycoprotein. J Biol Chem, 2004; 279: 5967-5974.

47. Yamanaka $M$, Eda $S$, Beppu $M$, Carbohydrate chains and phosphatidylserine successively work as signals for apoptotic cell removal. Biochem Biophys Res Commun, 2005; 328: 273-280.

48. Schlegel $R A$, Callahan $M K$, Williamson $P$. The central role of phosphatidylserine in the phagocytosis of apoptotic thymocytes. Ann N Y Acad Sci, 2000; 926: 217-225.

49. Marguet D, Luciani MF, Moynault A, Williamson $P$, Chimini G, Engulfment of apoptotic cells involves the redistribution of membrane phosphatidylserine on phagocyte and prey. Nat Cell Biol, 1999; 1: 454-456.

50. Hoffmann $P R$, deCathelineau $A M$, Ogden $C A$, Leverrier $Y$, Bratton $D L$, Daleke $D L$, Ridley AJ, Fadok VA, Henson PM, Phosphatidylserine (PS) induces PS receptormediated macropinocytosis and promotes clearance of apoptotic cells. $J$ Cell Biol, 2001; 155: 649-659.

51. Gregory CD, CD14-dependent clearance of apoptotic cells: relevance to the immune system. Curr Opin Immunol, 2000; 12: 27-34.

52. Li MO, Sarkisian MR, Mehal WZ, Rakic P. Flavell RA, Phosphatidylserine receptor is required for clearance of apoptotic cells. Science, 2003; 302: 1560-1563.

53. Bose J, Gruber $A D$, Helming $L$, Schiebe $S$, Wegener $I$, Hafner $M$, Beales $M$, Kontgen $F$, Lengeling $A$, The phosphatidylserine receptor has essential functions during embryogenesis but not in apoptotic cell removal. J Biol, 2004; 3: 15. 
54. Cikala $M$, Alexandrova $O$. David $C N$, Proschel $M$, Stiening $B$, Cramer $P$, Bottger $A$, The phosphatidylserine receptor from Hydra is a nuclear protein with potential Fe(II) dependent oxygenase activity. BMC Cell Biol, 2004: 5: 26.

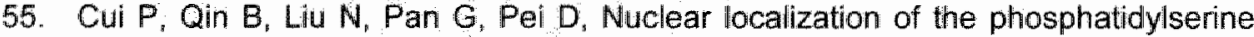
receptor protein via multiple nuclear localization signals. Exp Cell Res, 2004; 293 : 154-163.

56. Williamson $P$, Schlegel RA, Hide and seek: the secret identity of the phosphatidylserine receptor. J Biol, 2004; 3: 14.

57. Fadok VA, Bratton DL, Konowal A, Freed PW, Westcott JY, Henson $P M$, Macrophages that have ingested apoptotic cells in vitro inhibit proinflammatory cytokine production through autocrine/paracrine mechanisms involving TGF-beta, PGE2, and PAF. J Clin Invest, 1998; 101: 890-898.

58. Stern $M$, Savill $J$, Haslett $C$. Human monocyte-derived macrophage phagocytosis of senescent eosinophils undergoing apoptosis. Mediation by alpha $v$ beta 3/CD36/thrombospondin recognition mechanism and lack of phlogistic response. Am J Pathol, 1996; 149: 911-921.

59. Meagher LC, Savill JS, Baker A, Fuller RW, Haslett C, Phagocytosis of apoptotic neutrophils does not induce macrophage release of thromboxane B2. J Leukoc Biol 1992; 52: 269-273.

60. McDonald PP, Fadok VA, Bratton D, Henson PM, Transcriptional and translational requlation of inflammatory mediator production by endogenous TGF-beta in macrophages that have ingested apoptotic cells. J Immunol, 1999; 163: 6164-6172.

61. Savill J, Dransfield I, Gregory $C_{\text {, Haslett }} \mathbb{C}_{*}$ A blast from the past: clearance of apoptotic cells regulates immune responses. Nat Rev Immunol, 2002; 2: 965-975.

62. Voll RE, Herrmann $M$, Roth $E A$ stach $C_{*}$, Kalden JR, Girkontaite I, Immunosuppressive effects of apoptotic cells. Nature, 1997; 390: 350-351.

63. Fadok VA, McDonald PP, Bratton DL, Henson PM, Regulation of macrophage cytokine production by phagocytosis of apoptotic and post-apoptotic cells. Biochem Soc Trans, $1998 ; 26: 653-656$.

64. Huynh ML, Fadok VA, Henson PM, Phosphatidylserine-dependent ingestion of apoptotic cells promotes TGF-betal secretion and the resolution of inflammation. $J$ Clin Invest, $2002 ; 109: 41-50$.

65. Szondy $Z$, Sarang $Z$, Molnar $P$, Nemeth $T$, Piacentini $M$, Mastroberardino $P G$, Falasca L, Aeschlimann D, Kovacs J. Kiss I, Szegezdi E, Lakos G, Rajnavolgyi E. Birckbichler PJ, Melino $G$, Fesus L, Transglutaminase 2-t mice reveal a phagocytosis-associated crosstalk between macrophages and apoptotic cells. Proc Nall Acad Sci U S A, 2003; 100: 7812-7817.

66. Fadok VA, Bratton DL, Guthrie L, Henson PM, Differential effects of apoptotic versus lysed cells on macrophage production of cytokines: role of proteases. J Immunol, 2001; 166: 6847-6854.

67. Rosen $A_{0}$ Casciola-Rosen $L$, Clearing the way to mechanisms of autoimmunity. Nat Med, 2001; 7: 664-665.

68. Asano $K$, Miwa $M$, Miwa $K$, Hanayama $R$, Nagase $H$, Nagata $S$, Tanaka $M$, Masking of phosphatidylserine inhibits apoptotic cell engulfment and induces autoantibody production in mice. $J$ Cell Biol, 2004: 166: 13.

69. Ren Y, Tang J, Mok MY, Chan AW, Wu A, Lau CS, Increased apoptotic neutrophils and macrophages and impaired macrophage phagocytic clearance of apoptotic neutrophils in systemic lupus erythematosus. Arthritis Rheum, 2003:48: 28882897 
70. Baumann 1, Kolowos W, Vall RE, Manger B, Gaipl U, Neuhuber WL, Kirciner T, Kalden JR, Herrmann $M$, Impaired uptake of apoptotic cells into tingible body macrophages in germinal centers of patients with systemic lupus erythematosus. Arthritis Rheum, 2002; 46: 191-201.

71. Khan $M_{\text {a }}$ Pelengaris $S$, Cooper $M_{3}$ Smith $C_{k}$ Evan $G$, Betteridge J, Oxidised lipoproteins may promote inflammation through the selective delay of engulfment but not binding of apoptotic cells by macrophages. Atherosclerosis, 2003; 171: 2129.

72. Bombeli $T$, Karsan A, Tait JF, Harlan JM, Apoptotic vascular endothellal cells become procoagulant. Blood, 1997; 89: 2429-2442.

73. Flynn PD, Byrne CD, Baglin TP, Weissberg PL, Bennett MR, Thrombin generation by apoptotic vascular smooth muscle cells. Blood, 1997; 89:4378-4384.

74. Casciola-Rosen L, Rosen A. Petri M. Schlissel M. Surface blebs on apoptotic cells are sites of enhanced procoagulant activity: implications for coagulation events and antigenic spread in systemic lupus erythematosus. Proc Nall Acad Sci U S A. 1996; 93: 1624-1629.

75. Aupeix $K$, Toti $F$, Satta $N$, Bischoff $P$, Freyssinet $J M$, Oyxsterols induce membrane procoagulant activity in monocytic THP-1 cells. Biochem J, 1996; 314 (Pt 3): 1027 . 1033.

76. Mallat Z, Hugel B, Ohan J, Leseche G, Freyssinet JM, Tedgui A, Shed membrane microparticles with procoagulant potential in human atherosclerotic plaques: a role for apoptosis in plaque thrombogenicity. Circulation, 1999; 99: 348-353.

77. Mallat $Z$, Benamer $H$, Hugel $B$, Benessiano J, Steg PG, Freyssinet JM, Tedgui $A_{\text {. }}$ Elevated levels of shed membrane microparticles with procoagulant potential in the peripheral circulating blood of patients with acute coronary syndromes. Circulation, 2000; 101: 841-843.

78. Wang $\mathrm{J}$, Weiss 1 , Svoboda $\mathrm{K}, \mathrm{K}$ waan $\mathrm{HC}$, Thrombogenic role of cells undergoing apoptosis. Br J Haematol, 2001; 115: 382-391.

79. Geisow MJ, Fritsche U, Hexham JM, Dash B, Johnson T, A consensus amino-acid sequence repeat in Torpedo and mammalian $\mathrm{Ca} 2+$-dependent membrane-binding proteins. Nature, 1986; 320: 636-638.

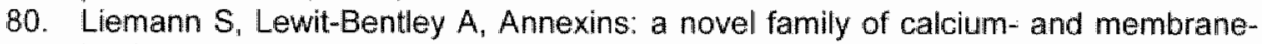
binding proteins in search of a function. Structure, 1995; 3:233-237.

81. Dumont EA, Hofstra L, van Heerde WL, van den Eijnde S, Doevendans PA, DeMuinck $E$, Daemen MA, Smits JF, Frederik $P$, Wellens $H J$, Daemen MJ, Reutelingsperger $\mathrm{CP}$, Cardiomyocyte death induced by myocardial ischemia and reperfusion: measurement with recombinant human annexin- $V$ in a mouse model. Circulation, 2000; 102: 1564-1568.

82. Dumont EA, Reutelingsperger CP, Smits JF, Daemen MJ, Doevendans PA, Wellens $H J$, Hofstra $L$, Real-time imaging of apoptotic cell-membrane changes at the single-cell level in the beating murine heart. Nat Med" 2001; 7:1352-1355.

83. Hofstra L, Liem IH, Dumont EA, Boersma HH, van Heerde WL, Doevendans PA, De Muinck $E$, Wellens $H J$, Kemerink GJ, Reutelingsperger $C P$, Heidendal GA, Visualisation of cell death in vivo in patients with acute myocardial infarction. Lancet, 2000; 356: 209-212.

84. Hofstra L, Dumont EA, Thimister PW, Heidendal GA, DeBruine AP, Elenbaas TW. Boersma $\mathrm{HH}$, van Heerde $W L$, Reutelingsperger $\mathrm{CP}$, In vivo detection of apoptosis in an intracardiac tumor. Jama, 2001; 285: 1841-1842. 
85. Vriens $P W$, Blankenberg $F G_{n}$ Stoot $J H$, Ohtsuki $K_{n}$ Berry GJ, Tait JF, Strauss HW. Robbins $R C$. The use of technetium $T c 99 \mathrm{~m}$ annexin $V$ for in vivo imaging of apoptosis during cardiac allograft rejection. J Thorac Cardiovasc Surg, 1998; 116 : 844-853.

86. Blankenberg FG, Katsikis PD, Tait JF, Davis RE, Naumovski L, Ohtsuki $K_{n}$ Kopiwoda S, Abrams MJ, Strauss HW, Imaging of apoptosis (programmed cell death) with $99 \mathrm{mTC}$ annexin $V$. I Nuc/ Med. 1999; 40: 184-191.

87. Reutelingsperger $\mathrm{CP}$. Hornstra $\mathrm{G}$, Hemker $\mathrm{HC}$, Isolation and partial purification of a novel anticoagulant from arteries of human umbilical cord. Eur I Biochem 1985; 151: $625-629$.

88. Romisch $J$, Seiffge $D$, Reiner $G_{3}$ Paques EP, Heimburger $N_{1}$ In-vivo antithrombotic potency of placenta protein 4 (annexin V). Thromb Res, 1991; 61: 93-104.

89. Tait JF, Frankenberry DA, Shiang $R$, Murray JC, Adler DA, Disteche $C M$, Chromosomal localization of the human gene for annexin $V$ (placental anticoagulant protein I) to $4 \mathrm{q} 26-\mathrm{m}-\mathrm{q} 28$. Cytogenet Cell Genet, 1991; 57 : $187-192$.

90. Fernandez MP, Morgan RO. Fernandez MR, Carcedo MT, The gene encoding human annexin $V$ has a TATA-less promoter with a high $G+C$ content. Gene, 1994; 149: $253-260$.

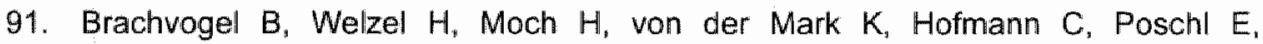
Sequential expression of annexin $A 5$ in the vasculature and skeletal elements during mouse development. Mech Dev, 2001; 109: 389-393.

92. Carcedo MT, Iglesias JM, Bances P, Morgan RO, Fernandez MP. Functional analysis of the human annexin A5 gene promoter: a downstream DNA element and an upstream long terminal repeat regulate transcription. Biochem $J, 2001 ; 356$ : 571-579.

93. Morgan RO, Fernandez MP. Annexin gene structures and molecular evolutionary genetics. Cell Mol Life Sci, 1997; 53: 508-515.

94. Rodriguez-Garcia MI, Morgan RO, Fernandez MR, Bances P, Fernandez MP, Mouse annexin $V$ genomic organization includes an endogenous retrovirus. Biochem J, 1999; 337 (Pt 1): 125-131.

95. Rodriguez-Garcia MI, Kozak CA, Morgan RO, Fernandez MP, Mouse annexin V chromosomal localization, cDNA sequence conservation, and molecular evolution. Genomics, 1996; 31: 151-157.

96. Huber R, Romisch J, Paques EP. The crystal and molecular structure of human annexin $V_{\text {, }}$ an anticoagulant protein that binds to calcium and membranes. Embo $J$, 1990; $9: 3867-3874$

97. Huber R, Schneider M, Mayr I, Romisch J, Paques EP. The calcium binding sites in human annexin $V$ by crystal structure analysis at 2.0 A resolution. Implications for membrane binding and calcium channel activity. FEBS Left, 1990; 275: 15-21.

98. Tait JF, Gibson D, Phospholipid binding of annexin V: effects of calcium and membrane phosphatidylserine content. Arch Biochem Biophys, 1992; 298: 187191.

99. Andree HA, Reutelingsperger CP. Hauptmann R, Hemker HC, Hermens WT, Willems GM, Binding of vascular anticoagulant alpha (VAC alpha) to planar phospholipid bilayers. J Biol Chem, 1990; 265: 4923-4928.

100. Isas JM, Cartailler JP, Sokolov $Y$, Patel DR, Langen $R$, Luecke $H_{*}$, Hall JUE, Haigler $H T$, Annexins $V$ and $X I I$ insert into bilayers at mildly acidic $p H$ and form ion channels. Biochemistry, 2000; 39: 3015-3022. 
101. Oling $F$, Bergsma-Schutter W. Brisson $A_{*}$. Trimers, dimers of trimers, and trimers of trimers are common building blocks of annexin a5 two-dimensional crystals. of Struct Biol, 2001; 133: 55-63.

102. Reviakine I, Bergsma-Schutter W, Mazeres-Dubut $C$. Govorukhina N. Brisson A, Surface topography of the $\mathrm{p} 3$ and $\mathrm{p} 6$ annexin $\mathrm{V}$ crystal forms determined by atomic force microscopy. J Struct Biol, 2000; 131: 234-239.

103. Zanotti G, Malpeli G, Gliubich F, Folli C, Stoppini M, Olivi L, Savoia A. Berni R, Structure of the trigonal crystal form of bowine annexin IV. Biochem J, 1998; 329 ( Pt 1): $101-106$.

104. Newman $R$, Tucker $A$, Ferguson $C_{n}$ Tsernoglau $D$, Leonard $K$, Crumpton $M J$, Crystallization of p68 on lipid monolayers and as three-dimensional single crystals. J Mol Biol, 1989; 206: 213-219.

105. Langen R, Isas JM, Luecke $H$, Haigler HT, Hubbell WL, Membrane-mediated assembly of annexins studied by site-directed spin labeling. J Biol Chem, 1998; 273: $22453-22457$.

106. Reutelingsperger $C P$, van Heerde $W L$, Annexin $V_{v}$ the regulator of phosphatidylserine-catalyzed inflammation and coagulation during apoptosis. Cell Mol Life Sci, 1997; 53: 527-532.

107. Tait JF, Gibson D, Fujikawa $K$, Phospholipid binding properties of human placental anticoagulant protein-I, a member of the lipocortin family. J Biol Chem, 1989; 264 : 7944-7949.

108. Thiagarajan $P$, Benedict $C R$, Inhibition of arterial thrombosis by recombinant annexin $V$ in a rabbit carotid artery injury model. Circulation, 1997; 96: 2339-2347.

109. Mira JP, Dubois T, Oudinet JP, Lukowski S, Russo-Marie F, Geny B, Inhibition of cytosolic phospholipase $A 2$ by annexin $V$ in differentiated permeabilized HL-60 cells. Evidence of crucial importance of domain I type II Ca2+-binding site in the mechanism of inhibition. J Biol Chem, 1997; 272: 10474-10482.

110. Schlaepfer DD, Jones J. Haigler HT, Inhibition of protein kinase $C$ by annexin $V$. Biochemistry, 1992; 31: 1886-1891.

111. Capila I, Hernaiz MJ, Mo YD, Mealy TR, Campos B, Dedman JR, Linhardt RJ, Seaton BA, Annexin $V$-heparin oligosaccharide complex suggests heparan sulfate-mediated assembly on cell surfaces. Structure (Camb), 2001; 9: 57-64.

112. Capila I, VanderNoot VA, Mealy TR, Seaton BA, Linhardt RJ, Interaction of heparin with annexin $V$. FEBS Lett, 1999; 446: 327-330.

113. Ishitsuka $R$, Kojima $K$, Utsumi $H$, Ogawa $H$, Matsumoto 1, Glycosaminoglycan binding properties of annexin IV, $V$, and $V 1 . J$ Bjol Chem, 1998; 273: 9935-9941.

114. Mollenhauer $\mathrm{J}$, von der Mark $\mathrm{K}$, Isolation and characterization of a collagen-binding glycoprotein from chondrocyte membranes. Embo J, 1983; 2: 45-50.

115. von der Mark K, Mollenhauer J. Muller PK, Pfaffle M, Anchorin Cll, a type II collagen-binding glycoprotein from chondrocyte membranes "Ann $N$ Y Acad Sci, 1985; 460: 214-223.

116. Huber $\mathbb{R}_{0}$ Berendes $R$, Burger $A$, Schneider $M$, Karshikov $A$, Luecke $H$, Romisch $J$, Paques $E$, Crystal and molecular structure of human annexin $V$ after refinement. Implications for structure, membrane binding and ion channel formation of the annexin family of proteins. $J \mathbf{M o l}$ Biol, $1992 ; 223: 683-704$.

117. Liemann $S$, Benz $J$, Burger A, Voges D, Hofmann A, Huber $R$, Gottig P, Structural and functional characterisation of the voltage sensor in the ion channel human annexin V. IMol Biol, 1996; 258: 555-561. 
118. Rojas $E$, Pollard $H B$, Haigler $H T$, Parra $C$, Burns $A L$, Calcium-activated endonexin II forms calcium channels across acidic phospholipid bilayer membranes. J Biol Chem, 1990; 265: 21207-21215.

119. Kubista $H$, Hawkins TE, Patel DR, Haigler HT, Mass SE, Annexin 5 mediates a peroxide-induced $\mathrm{Ca}(2+)$ influx in B cells: Curr Biol, 1999; 9: 1403-1406.

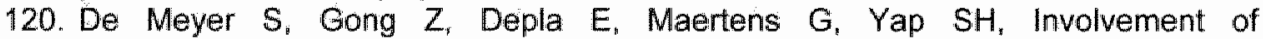
phosphatidylserine and non-phospholipid components of the hepatitis B virus envelope in human Annexin $\mathrm{V}$ binding and in HBV infection in vitro. J Hepatol, $1999 ; 31: 783-790$.

121. Huang RT, Lichtenberg $B$, Rick $O$, Involvement of annexin $V$ in the entry of influenza viruses and role of phospholipids in infection. FEBS Left, 1996; 392: 5962.

122. Christmas $P$. Callaway J, Fallon $J$, Jones $J$, Haigler $H T$, Selective secretion of annexin 1, a protein without a signal sequence, by the human prostate gland. $J$ Biol Chem, 1991; 266: 2499-2507.

123. Brachvogel B, Dikschas J, Moch $H$, Welzel $H$, von der Mark $K_{n}$ Hofmann $C$, Poschl $\mathrm{E}$, Annexin A5 is not essential for skeletal development. Mol Cell Biol, 2003; 23 : 2907-2913.

124. Rand $J H_{*}$ "'Annexinopathies"--a new class of diseases. $N$ Engl $J$ Med" $1999 ; 340$ : 1035-1036.

125. Rand $J H$, Wu $X X$, Antibody-mediated disruption of the annexin- $V$ antithrombotic shield: a new mechanism for thrombosis in the antiphospholipid syndrome. Thromb Haemost, 1999; 82: 649-655.

126. Rand $J H$, Wu XX, Andree HA, Lockwood CJ, Guller S, Scher J, Harpel PC, Pregnancy loss in the antiphospholipid-antibody syndrome--a possible thrombogenic mechanism. N Engl J Med, 1997; 337: 154-160.

127. Rand JH, Wu XX Quinn AS, Chen PP "McCrae KR, Bovill EG, Taatjes DJ, Human monoclonal antiphospholipid antibodies disrupt the annexin $A 5$ anticoagulant crystal shield on phospholipid bilayers: evidence from atomic force microscopy and functional assay. Am J Pathol, 2003; 163: 1193-1200.

128. Setty YN, Komatireddy GR, Antiphospholipid antibodies in systemic lupus erythematosus and the antiphospholipid syndrome. Front Biosci, 2001; 6; E207212.

129. Rodriguez-Garcia MI, Fernandez JA, Rodriguez A, Fernandez MP, Gutierrez $C_{*}$ Torre-Alonso JC, Annexin $V$ autoantibodies in theumatoid arthritis. Ann Rheum Dis, 1996; 55: 895-900.

130. van Heerde WL, Maassen C, Lux PAG, Derksen RHWM, de Groot PG, The presence of anti-phospholipid antibodies is not related to increased levels of Annexin A5 in plasma. Blood, 2003; 1: 532-536.

131. Osende Olea $J_{n}$ [Annexin $V$ levels in young patients with acute myocardial infarction: new answers bring new questions]. Rev Esp Cardiol, 2002; 55: 1223 1225.

132. Roldan V, Marin F, Pineda J, Marco P, Corral J, Climent V. Garcia A Martinez JG, Sogorb $F$, [Annexin V levels in survivors of early myocardial infarction]. Rev Esp Cardiol, 2002; 55: 1230-1234.

133. Wang $X$, Campos $B$, Kaetzel MA, Dedman JR, Annexin $V$ is critical in the maintenance of murine placental integrity. Am J Obstet Gynecol, 1999; 180: 10081016. 
134. Shu $F$, Sugimura $M$, Kanayama $N$, Kobayashi $H$, Kobayashi $T$, Terao $T$, Immunohistochemical study of annexin $V$ expression in placentae of preeclampsia. Gynecol Obstet invest, 2000; 49: 17-23.

135. Konijnenberg $A$, Stokkers EW, wan der Post JA, Schaap MC, Boer K, Bleker OP, Sturk A, Extensive platelet activation in preeclampsia compared with normal pregnancy: enhanced expression of cell adhesion molecules. Am $J$ Obstet Gynecol, 1997; 176: 461-469.

136. Koopman $G_{*}$ Reutelingsperger CP, Kuijten GA, Keehnen RM, Pals ST, van Oers $\mathrm{MH}_{4}$ Annexin $\mathrm{V}$ for flow cytometric detection of phosphatidy/serine expression on $\mathrm{B}$ cells undergoing apoptosis. Blood, 1994; 84: 1415-1420.

137. Vermes I, Haanen $C$, Steffens-Nakken $H$, Reutelingsperger $C$, A novel assay for apoptosis. Flow cytometric detection of phosphatidylserine expression on early apoptotic cells using fluorescein labelled Annexin $V$. $J$ Immunol Methods, 1995: 184: $39-51$.

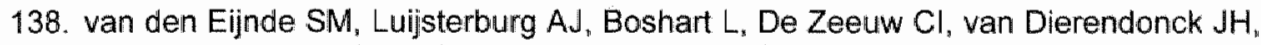
Reutelingsperger CP, Vermeij-Keers $C$, In situ detection of apoptosis during embryogenesis with annexin $\mathrm{V}$ : from whole mount to ultrastructure. Cytometry" 1997; 29: 313-320.

139. Narula J, Acio ER, Narula N, Samuels LE, Fyfe B, Wood D, Fitzpatrick JM, Raghunath PN, Tomaszewski. JE, Kelly C, Steinmetz N, Green A, Tait JF, Leppo J, Blankenberg FG, Jain D, Strauss HW, Annexin-V imaging for noninvasive detection of cardiac allograft rejection. Nat Med, 2001; 7: 1347-1352.

140. Kietselaer BL, Reutelingsperger CP. Heidendal GA, Daemen MJ, Mess $\mathbf{W H}_{\text {, }}$ Hofstra L, Narula J, Noninvasive detection of plaque instability with use of radiolabeled annexin A5 in patients with carotid-artery atherosclerasis. $N$ Engl $I$ Med, 2004; 350: 1472-1473.

141. Oling $F$, Santos JS, Govorukhina N, Mazeres-Dubut $C$, Bergsma-Schutter $W$, Oostergetel G, Keegstra W, Lambert O, Lewit-Bentley A, Brisson A, Structure of membrane-bound annexin A5 trimers: a hybrid cryo-EM - X-ray crystallography study. J Mol Biol, 2000; 304: 561-573. 


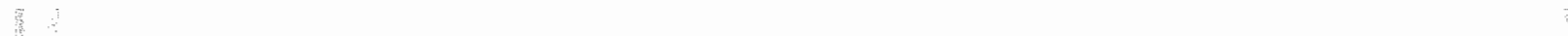




\section{CHAPTER 2}

SCREENING FOR ANNEXIN A5 GENE MUTATIONS:

THE RISK OF THE C-1T MUTATION IN VENOUS THROMBOSIS AND MYOCARDIAL INFARCTION

Heidi Kenis", Carine J.M. Doggen ${ }^{2}$, Frits R. Rosendaal ${ }^{2,3}$, Rogier M. Bertina ${ }^{3}$, Hans L. Vos ${ }^{3}$, Jean-Maurice L.S. Lavergne ${ }^{4}$, Chris P.M. Reutelingsperger', Waander L. van Heerde ${ }^{5}$

1 Cardiovascular Research Institute Maastricht, Maastricht, the Netherlands

2 Department of Clinical Epidemiology, Leiden University Medical Center, Leiden, the Netherlands

${ }^{3}$ Haemostasis and Thrombosis Research Center, Leiden University Medical Center, Leiden, the Netherlands

4 Inserm U143 Hôppital de Bicêtre, Paris, France

5 University Medical Center St.Radboud, Nijmegen, the Netherlands

Based on J. Thromb. Haemost. 2003 Dec;1(12):2688-9. 


\section{ABSTRACT}

BACKGROUND: Annexin A5 binds with high affinity to negatively charged phospholipids on activated platelets and is abundantly present in atherosclerotic plaques. The phospholipid binding activity forms the basis of its anticoagulant activity. We screened for DNA variations in the annexin A5 gene in patients with venous thrombosis and validated our findings for the $\mathrm{C}-1 \mathrm{~T}$ mutation in two large case-control studies, of venous thrombosis and myocardial infarction.

METHODS AND RESULTS: Several mutations were identified: T-907C (promoter region); a C-368 insertion (exon 1); G-367A and G-296T (both in the untranslated exon 1); $\mathrm{C}-1 \mathrm{~T}$ in exon 2 ; and T771C (exon 11, no amino acid substitution). In addition, two mutations were observed in introns 5 and 10 outside splicing regions. The C-1T mutation in the Kozak sequence was further analyzed in two population-based case-control studies on venous thrombosis and myocardial infarction. We found no increased risk of venous thrombosis (odds ratio, $0.9, \mathrm{Cl} 95=0.7$ to 1.2 ) for the T-variant, but a slightly increased risk of myocardial infarction (odds ratio, $1.3, \mathrm{Cl} 95=1.0-1.7$ ). The risk was highest in men aged less than 50 (odds ratio, $1.5, \mathrm{Cl} 95=0.9-2.4$ ). Stratification of the case-control studies by factor $V$ Leiden or the prothrombin 20210A mutation led to a higher relative risk for the simultaneous presence of one of these mutations and the $\mathrm{T}$ allele, in particular for myocardial infarction, where among factor $\mathrm{V}$ Leiden and prothrombin 20210A carriers, carriers of the $T$ allele had a three-fold increased risk of myocardial infarction.

CONCLUSIONS: The C-1T mutation in the annexin A5 gene is not related to venous thrombosis but may be associated with myocardial infarction, especially in young men and in combination with prothrombotic defects. 


\section{INTRODUCTION}

Annexin A5 is a strong anticoagulant protein in vitro. This anticoagulant activity is due to its high affinity for negatively charged phospholipids ${ }^{4}$. Annexin A5 is present in the circulation and as such may effect blood coagulation. Rand et al. showed that anti-phospholipid antibodies can displace endogenous annexin A5 from placental villi ${ }^{2}$. On basis of this observation it has been hypothesized that the lack of annexin A5 on placental villi, due to anti-phospholipid antibodies, is responsible for thrombosis and pregnancy loss in patients with the antiphospholipid antibody syndrome ${ }^{3}$. More information about the relevance of annexin $A 5$ in coagulation can be obtained by screening for aberrations in the annexin $\mathrm{A} 5$ gene.

The annexin A5 gene is located on chromosome 4q26-28 and comprises an untranslated exon 1 plus 12 coding exons, which span a region of approximately $29 \mathrm{~kb}^{4}$. The annexin A5 gene contains a $5^{\prime}$ promoter region of $1200 \mathrm{bp}$ and a $3^{\prime}$ downstream region containing a poly-adenylation site. The absence of a typical TATA box and the presence of GC-rich regions containing putative Sp1-binding sites in the promoter characterize the gene as a "housekeeping" gene and account for its broad pattern of expression ${ }^{5}$. So far, only one study examined the relation between the $\mathrm{C}-1 \mathrm{~T}$ mutation in the annexin A5 gene and hemorrhagic and thrombotic disorders ${ }^{6}$.

We set out to identify new genetic variants of annexin A5, by screening the gene for mutations in a panel of 42 individuals with venous thrombosis and compared the prevalence in a control population of 65 healthy volunteers. We found the $\mathrm{C}-1 \mathrm{~T}$ mutation, located in the Kozak sequence and important for translation efficiency ${ }^{7},{ }^{8}$, and tested this mutation in two large case-control studies, of venous thrombosis and myocardial infarction.

\section{MATERIALS AND METHODS}

\section{STUDY POPULATION}

In the identification study, forty-two unrelated patients with venous thrombosis were analyzed for mutations in the annexin A5 gene by dHPLC analysis. Subsequently, sixty-five healthy volunteers were screened to determine the prevalence of the mutations found in this patient population.

Validation was done in two large population-based case-contral studies: the Leiden Thrombophilia Study (LETS) on venous thrombosis and the Study of 
Myocardial Infarction Leiden (SMLEE) on myocardial infarction. All individuals gave informed consent.

The design of the population-based case-control study (LETS) has been described previously ${ }^{9}$. Briefly 474 consecutive patients with a first episode of deep-vein thrombosis were selected from the files of three anticoagulation clinics in the Netherlands. All patients were younger than 70 years of age and were not diagnosed with malignant disorders. Controls were 474 acquaintances of patients or partners of other patients, matched for age and sex with the cases. We had analyzable material for 471 patients and 472 controls.

In the SMILE population, patients were 560 men below the age of 70 years with a first myocardial infarction. Controls $(n=646)$ were also men, frequency matched to the patients on 10-year age groups, who had undergone an orthopedic intervention and had received prophylactic anticoagulants for a short period after this intervention. They did not have a history of myocardial infarction and had not used anticoagulants for at least 6 months before participation in this study. Both patients and controls were born in the Netherlands. We had analyzable material for 554 patients and 635 controls. Full details of SMILE have been published elsewhere ${ }^{10}$.

\section{GENOMIC DNA EXTRACTION}

In the identification study, genomic DNA was extracted from whole blood samples anticoagulated with EDTA using PUREGENE DNA Isolation Kit (Gentra Systems) according to the manufacturer's instructions. The concentration was adjusted to $50 \mathrm{ng} \mu \mathrm{ll}^{-1}\left(\mathrm{~A}_{260 \mathrm{~nm}}\right)$ and the samples were stored in TE buffer (10 mM Tris ( $\mathrm{pH} 7.4), 1 \mathrm{mM}$ EDTA) at $4^{\circ} \mathrm{C}$. In the validation studies (the LETS and the SMILE study), genomic DNA was extracted from white blood cells by standard salting out procedures ${ }^{11}$.

\section{AMPLIFICATION OF GENOMIC DNA FOR DHPLC ANALYSIS}

$P C R$ reactions were carried out in a final volume of $50 \mu$ reaction mixture containing $1 \mu$ genomic DNA (50 ng), $1.5 \mathrm{U}$ Taq DNA polymerase (Pharmacia), $5 \mu \mathrm{lPCR}$ reaction buffer (10x) containing $1.5 \mathrm{mM} \mathrm{MgCl}, 0.2 \mathrm{mM}$ of each dNTP and $10 \mathrm{pmol}$ of forward and reverse primer. The PCR reactions were performed in a Perkin Elmer 9700 thermocycler (PE Applied Biosystems). Cycling conditions for PCR were as follows, an initial denaturation at $94^{\circ} \mathrm{C}$ for $10 \mathrm{~min}$ followed by 35 cycles of denaturation at $94^{\circ} \mathrm{C}$ for $30 \mathrm{~s}$, annealing for $30 \mathrm{~s}$ (temperatures were adjusted for individual amplicons, table 1) and elongation at $72^{\circ} \mathrm{C}$ for $30 \mathrm{~s}$. The last cycle was followed by an additional elongation step of $72^{\circ} \mathrm{C}$ for 7 min and a cooling step to $4^{\circ} \mathrm{C}$. Amplicons which were subjected to 
dHPLC analysis, were mixed with equal amounts of wild-type amplified DNA, denaturated at $94^{\circ} \mathrm{C}$ for $10 \mathrm{~min}$ and gradually reannealed at $37^{\circ} \mathrm{C}$ for $45 \mathrm{~min}$ to form heteroduplexes before being stored at $4^{\circ} \mathrm{C}$. The wild-type DNA was obtained from a healthy volunteer of whom the amplified part of the annexin A5 gene was fully sequenced.

\section{DHPLC ANALYSIS}

Mutation detection by dHPLC is based upon the ability to discriminate between hetero- and homoduplexes. At a specific column temperature i.e., at which the DNA begins to denaturate and loses its affinity to the column, heteroduplexes elute earlier (visible by a decrease in retention time) from the column as compared to homoduplexes due to their lower melting temperature characterized by a nucleotide mismatch.

Prior to dHPLC analysis, the melting temperature was calculated for each individual fragment by the dHPLC Melt program (http://insertion.stanford.edu/melt.html) and by the Wavemaker program (Transgenomic, Crew, UK). dHPLC analysis was performed on an automated DNA fragment analysis system (Transgenomic). Mixed amplicons were automatically injected onto the DNA separation column (Transgenomic). Fragments were eluted with a linear acetonitril gradient of $2 \%$ per min at a flow rate of $0.9 \mathrm{ml} \mathrm{min}^{-1}$. The gradient was created by a mobile liquid phase of a mixture of $0.1 \mathrm{M}$ triethylammonium acetate $(\mathrm{pH} \mathrm{7.0)}$ (buffer $\mathrm{A}$, Transgenomic) and a liquid phase consisting of buffer $A$ with $25 \%$ acetonitrile (buffer $B$ ). A linear gradient of buffer B ( 50 to $66 \%$ ) with buffer A was used with a slope of $2 \%$ per minute. Eluted DNA fragments were detected with UV absorption at a wavelength of $260 \mathrm{~nm}$.

\section{DNA SEQUENCING}

Amplicons with an altered elution profile were sequenced using the big dye sequence reaction kit according to the instructions of the manufacturer ( $P E$ Applied Biosystems) and the same forward and reverse primers as for amplification. Amplicons were purified with the Centriflex gel filtration cartridge (Edge Biosystems) and analyzed on the $A B \mid 310$ sequencer (PE Applied Biosystems). The sequences were compared with sequences obtained from an individual who had no mutations in the amplified region.

\section{RESTRICTION ENZYME ANALYSIS}

In the identification study, genetic changes observed by dHPLC analysis were confirmed by restriction enzyme digestion in case an altered restriction site was 
obtained. The $\mathrm{C}-1 \mathrm{~T}$ mutation in exon 2 was confirmed by restriction digestion with $\mathrm{Ncol}$ and the mutation in intron 5 with Bsml (data not shown). The digests were analyzed by PAGE ( $7 \%$ ), after staining by ethidium bromide.

In the validation studies (the LETS and the SMILE study), the C-1T mutation was determined by restriction digestion with $\mathrm{Ncol}$. The digests were analyzed on a $3 \%$ agarose gel, after staining by ethidium bromide.

\section{STATISTICAL ANALYSIS}

An odds ratio (OR) was calculated as a measure of relative risk. This odds ratio estimates the risk of a myocardial infarction or venous thrombosis in the presence of a risk factor relative to the risk in the absence of the particular risk factor, the reference category. A $95 \%$ confidence interval was calculated according to the method of Woolf ${ }^{12}$, based on a Poisson distribution.

\section{RESULTS}

\section{MUTATION ANALYSIS OF THE ANNEXIN A5 GENE IN 42 PATIENTS WITH VENOUS THROMBOSIS: THE IDENTIFICATION STUDY}

The 13 exons and the $1200 \mathrm{bp} 5^{\prime}$ promoter region of the annexin A5 gene were analyzed by dHPLC. Nineteen PCR reactions were designed which span these regions. For the exons, the primers were located in the introns flanking the splicing regions. The PCR primer sets and PCR conditions are shown in table 1. Based on the GenBank ${ }^{\text {(a) }}$ accession number U01681, our analysis revealed the presence of following mutations (table 2): a T/C transversion at position -907 was found in the non-coding promoter region containing an adenosine-rich, lowcomplexity segment located -953 to $-895 \mathrm{bp}$ upstream from ATG start codon. Two mutations were identified in the non-translated exon 1 at position G-296T and position G-367A. Furthermore, exon 1 contained an insertion of a $C$ at position -368 . Exon 2 contained a $\mathrm{C} / \mathrm{T}$ mutation at position -1 , located in the Kozak sequence. In the translated regions only one mutation was observed in exon 11 at position $\mathrm{T771C}$ not resulting in an amino acid substitution (Tyr257Tyr). Next, two intron mutations were observed in intron 5 and 10 , outside the splicing regions. Two mutations were confirmed by restriction fragment length polymorphism: the $\mathrm{C}-1 \mathrm{~T}$ mutation in exon 2 by Ncol restriction and the mutation in intron 5 by Bsml (data not shown). The prevalence of the mutations is shown in table 2 . The prevalence of the mutation in the promoter region was three-fold higher in the patient group $(76.2 \%)$ compared to the control population $(26.2 \%)$. The prevalence of the C-1T mutation was two-fold higher in the patient group (26.6\%) compared to the control population (14.8\%). 
TABLE 1. Annexin A5 gene primer set and experimental conditions for PCR and CHPLC analysis.

\begin{tabular}{|c|c|c|c|c|}
\hline \multicolumn{5}{|c|}{ ANNEXIN A5 GENE MUTATION ANALYSIS } \\
\hline PCR fragment & $\begin{array}{l}\text { Fragment } \\
\text { Length }\end{array}$ & Primers 5-3' & $\begin{array}{l}\text { Annealing } \\
\text { temp }(P C R)\end{array}$ & $\begin{array}{l}\text { Column } \\
\text { Hemp } \\
\text { (OHPLC) }\end{array}$ \\
\hline prom $-1704 /-1510$ & 194 & $\begin{array}{l}\text { s: GCA TCT AGT GTC GCA AAC TT } \\
\text { as: TCA GGA GGT ATT CAT GGG AC }\end{array}$ & 55 & 60 \\
\hline prom $-1698 / 1540$ & 158 & $\begin{array}{l}\text { si AGT GTC GCA AAC TIT TCC TC } \\
\text { as: AAA GGT CAA CAT GGC GGA TT }\end{array}$ & 50 & 60 \\
\hline prom $-1576 /-1191$ & 385 & $\begin{array}{l}\text { s: TTA TAT CCC GGA TGC TAA TC } \\
\text { as: CCA AAC GCG AAG GAG TCA AG }\end{array}$ & 50 & $57-59$ \\
\hline prom - $1291 /-930$ & 361 & $\begin{array}{l}\text { S: GCC ACG CTT CTG TCT ACG AC } \\
\text { as: GCT TCC TAG ATG GCC CTC TC }\end{array}$ & 50 & $56-57$ \\
\hline prom $-9924-713$ & 279 & $\begin{array}{l}\text { s: TTC AAA TAG CCC ACA TAC GC } \\
\text { as: GCC TCC CTG CCC TCT GTG AC }\end{array}$ & 56 & 57 \\
\hline prom $-661 /-388$ & 273 & $\begin{array}{l}\text { s: GGC GCG AGG ACA AGA GGT CT } \\
\text { as: GCT GGC GTT TCC GTT GCT TG }\end{array}$ & 60 & 66 \\
\hline exon $1-398 / 190$ & 209 & $\begin{array}{l}\text { S: CCG TTG CTT GGA TCA GTC TAG } \\
\text { GTG } \\
\text { as: CGT CCG CGC GAA TCC AGT }\end{array}$ & 61 & 64 \\
\hline exion 2 & 130 & $\begin{array}{l}\text { s: CGC TAA GCC CGA GGT TTC T } \\
\text { as: CGC AGC ATA CAA AGT TGT GG }\end{array}$ & 61 & $61-62$ \\
\hline exton 3 & 270 & $\begin{array}{l}\text { S: AAT AAT ACC ACT GTG TTT CG } \\
\text { as: CAT CTG TAA TCT AGC TCG Tा }\end{array}$ & 56 & 53 \\
\hline exion 4 & 267 & $\begin{array}{l}\text { s: AGA TCG TTG GGA GAG TAT GC } \\
\text { as: AAG TCG GAA TCA CAA AAT AA }\end{array}$ & 56 & 54.59 \\
\hline exion 5 & 222 & $\begin{array}{l}\text { s: AAT TTC TGC TGG TTA ACA AA } \\
\text { as: GGA AGT AAT TAC CAM AAC AA }\end{array}$ & 45 & 55 \\
\hline exion 6 & 216 & $\begin{array}{l}\text { 5: TAT AAA ATC TCC AAA CAG GG } \\
\text { as: ATC ATT TAC TGC GTG CCT CC }\end{array}$ & 51 & 57 \\
\hline exion 7 & 224 & $\begin{array}{l}\text { : TAC ATC GCT TTC ATT TGATT } \\
\text { as: TCA GCC CAG TCC AAC TTC AG }\end{array}$ & 50 & $56-57$ \\
\hline exon 8 & 309 & $\begin{array}{l}\text { s: GTG CAG GAT TGA TCT TAA TA } \\
\text { as: AAC CCATTA ACA AGA TTA TC }\end{array}$ & 47 & $55-56$ \\
\hline exon 9 & 171 & $\begin{array}{l}\text { S: GTT TGA AAT TTT TGC AGG CT } \\
\text { aS: CTG GCA TCT ATG CAC TIT CC }\end{array}$ & 51 & 57 \\
\hline exon 10 & 223 & $\begin{array}{l}\text { s: AAA GAG TGA TCC CTA CAT GA } \\
\text { as: TAT TTT CAG ATG CAG CCT CA }\end{array}$ & 56 & 55 \\
\hline exon 11 & 363 & $\begin{array}{l}\text { 5: GCC AGT GTC TAA GAA AAT AC } \\
\text { as: TGG GTT GAA TGT TAT AAG GO }\end{array}$ & 51 & 55 \\
\hline exon 12 & 171 & $\begin{array}{l}\text { 5: TTA AAG GGA GCT GGG ACA GAT } \\
\text { as: GCA AAG GAT TCC CAA ACG TA }\end{array}$ & 50 & $56-57$ \\
\hline exon 13 & 315 & $\begin{array}{l}\text { s: ATT TGT TGC CAG TTA TTT AG } \\
\text { as: AGA TCA GAA AGA AGC ACC AC }\end{array}$ & 50 & $55 \% 60$ \\
\hline
\end{tabular}

s: sense primer

as: antisense primer 
TABLE 2. Mutations in the annexin A5 gene and the prevalence of mutations in a group of patients with venous thrombosis $(n=42)$ and controls $(n=65)$ in the identification study.

\begin{tabular}{ccccc}
\hline Mutations & Region & $\begin{array}{c}\text { N patients }(\%) \\
(n=42)\end{array}$ & $\begin{array}{c}\text { N controls }(\%) \\
(n=65)\end{array}$ & AF $^{*}$ \\
\hline T.907C & promoter & $32(76.2)$ & $17(26.2)$ & 0.51 \\
ins C-368 & exon 1 & - & - & - \\
G-367A & exon 1 & $4(9.5)$ & nd & nd \\
G-296T & exon 1 & $4(9.5)$ & $2(3)$ & 0.17 \\
C-1T & exon 2 & $11(26.6)$ & $10(14.8)$ & 0.38 \\
A/G 23 bp 3 & intron 5 & $4(9.5)$ & $2(3)$ & 0.17 \\
G/A 39 bp 3' & intron 10 & $5(11.9)$ & $1(1.5)$ & 0.12 \\
T771C & exon 11 & $1(2.5)$ & 0 & 0 \\
\hline
\end{tabular}

Allelic frequency of the controls in the identification study.

$\mathrm{N}=$ number, $\mathrm{nd}=$ not done

RISK OF THROMBOSIS IN VALIDATION STUDIES: LETS AND SMILE STUDY

As the nucleotides, preceding the ATG initiator codon (Kozak sequence), are thought to be important in translation efficiency in eukaryotic cells we focused on the $\mathrm{C}-1 \mathrm{~T}$ mutation for subsequent validation. The prevalence of the $\mathrm{T}$ allele of the C-1T mutation in the control group of both studies, consisting of 635 subjects (SMILE) and 472 subjects (LETS) was similar (respectively 0.16 and 0.13 ). The C-1T mutation was not associated with the risk of venous thrombosis (odds ratio for heterozygous and homozygous carriers of the $\mathrm{T}$ allele versus homozygous $\mathrm{C}$ allele carriers was $0.9, \mathrm{Cl} 195=0.7$ to 1.2 ) (table 3 ). Stratification of the population by sex and age did not change these results.

In the study on myocardial infarction, T allele carriers had a slightly increased risk of myocardial infarction compared to $C$ allele carriers (odds ratio, 1.3, CI95 $=1.0-1.7$ ) (table 4 ). In patients, $34.3 \%$ carried the $T$ allele compared to 28.7 $\%$ in controls. This risk was more pronounced in men under age 50 (odds ratio, $1.5, \mathrm{Cl} 950.9-2.4$ ), although the confidence interval remained compatible with the absence of an effect. Stratification of the case-control studies by the presence or absence of the factor $V$ Leiden or the prothrombin 20210A mutation led to slightly higher relative risk for the simultaneous presence of one of these mutations and the T allele (table 5), in particular for myocardial infarction, where among factor $V$ Leiden and prothrombin 20210A carriers, carriers of the $T$ allele had a three-fold increased risk of myocardial infarction compared to $C$ allele carriers (table 6). 
TABLE 3. Genotypes of the annexin A5 mutation in a population with venous thrombosis (LETS).

\begin{tabular}{|c|c|c|c|}
\hline Annexin A5 & N patients (\%) & $\mathbb{N}$ controls $(\%)$ & Odds Ratio $(95 \% \mathrm{CI})$ \\
\hline \multicolumn{4}{|c|}{ Total popullation } \\
\hline $\mathrm{CC}$ & $364(77.3)$ & $356(75.4)$ & 1 \\
\hline$C T+T T$ & $107(22.7)$ & $116(24.6)$ & $0.9(0.7-1.2)$ \\
\hline Total & 471 & 472 & \\
\hline \multicolumn{4}{|l|}{$\leq 45$ years } \\
\hline $\mathrm{CC}$ & $175(75.4)$ & $175 .(75.1)$ & 1 \\
\hline $\mathrm{CT}+\mathrm{TT}$ & $57(24.6)$ & $58(24.9)$ & $1.0(0.6-1.5)$ \\
\hline Total & 232 & 23,3 & \\
\hline \multicolumn{4}{|l|}{$>45$ years } \\
\hline $\mathrm{CC}$ & $189(79.1)$ & $181(75.7)$ & 1 \\
\hline$C T+T T$ & $50(20.9)$ & $58(24.3)$ & $0.8(0.5-1.3)$ \\
\hline Total & 239 & 239 & \\
\hline
\end{tabular}

* Odds ratios, with $95 \%$ confidence interwal of CT $+T T$ genolypes versus CC genotype.

TABLE 4. Genotypes of the annexin A5 mutation in a population with myocardial infarction (SMILE).

\begin{tabular}{|c|c|c|c|}
\hline Annexin A5 & N patients $(\%)$ & $\mathbb{N}$ controls $(\%)$ & Odds ratio ( $95 \%$ Cl) \\
\hline \multicolumn{4}{|c|}{ Total population } \\
\hline $\mathrm{CC}$ & $364(65.7)$ & $453(71.3)$ & 1 \\
\hline $\mathrm{CT}+\mathrm{TT}$ & $190(34.3)$ & $182(28.7)$ & $1.3(1.0-1.7)$ \\
\hline Total & 554 & 635 & \\
\hline \multicolumn{4}{|l|}{$<50$ years } \\
\hline $\mathrm{CC}$ & $98(63.6)$ & $114(72.6)$ & 1 \\
\hline$C T+\mathbb{T T}$ & $56(36.4)$ & $43(27,4)$ & $1.5(0.9-2.4)$ \\
\hline Total & 154 & 157 & \\
\hline \multicolumn{4}{|l|}{$\geq 50$ years } \\
\hline $\mathrm{CC}$ & $266(66.5)$ & $339(70.9)$ & 1 \\
\hline $\mathrm{CT}+\mathrm{TT}$ & $134(33.5)$ & $139(29.1)$ & $1.2(0.9-1.6)$ \\
\hline Total & 400 & 478 & \\
\hline
\end{tabular}

Odds ratios, with $95 \%$ confidence interval of $C T+T T$ genotypes versus $\mathrm{CC}$ genotype. 
TABLE 5. Genotypes of the annexin A5 mutation in the LETS population and stratification by factor $V$ Leiden (FVL) and by prothrombin 20210A mutation (PT20210A) carriership.

\begin{tabular}{|c|c|c|c|}
\hline Annexin A5 & N patients $(\%)$ & N controls $(\%)$ & Odds Ratio $(95 \% \mathrm{Cl})$ \\
\hline \multicolumn{4}{|c|}{ Total population } \\
\hline $\mathrm{CC}$ & $364(77.3)$ & $356(75.4)$ & 1 \\
\hline $\mathrm{CT}+\mathrm{TT}$ & $107(22.7)$ & $116(24.6)$ & $0.9(0.7-1.2)$ \\
\hline Total & 471 & 472 & \\
\hline \multicolumn{4}{|l|}{ No FVL (GG) } \\
\hline $\mathrm{CC}$ & $298(78,6)$ & $345(75.3)$ & 1 \\
\hline $\mathrm{CT}+\mathrm{TT}$ & $81(21.4)$ & $113(24.7)$ & $0.8(0.6-1.1)$ \\
\hline Total & 379 & 458 & \\
\hline \multicolumn{4}{|c|}{ No PT mutation (GG) } \\
\hline $\mathrm{CC}$ & $343(77.6)$ & $347(75.3)$ & 1 \\
\hline$C T+\pi T$ & $99(22.4)$ & $114(24.7)$ & $0.9(0.6-1.2)$ \\
\hline Total & 442 & 461 & \\
\hline \multicolumn{4}{|c|}{ FVL/PT20210A } \\
\hline $\mathrm{CC}$ & $87(71.9)$ & $20(80.0)$ & 1 \\
\hline $\mathrm{CT}+\mathrm{TT}$ & $34(28.1)$ & $5(20.0)$ & $1.6(0.5-4.5)$ \\
\hline Total & 121 & 25 & \\
\hline
\end{tabular}

Odds ratios, with $95 \%$ confidence interval of $\mathrm{CT}+\mathrm{TT}$ genotypes versus CC genotype. 
TABLE 6. Genotypes of the annexin A5 mutation in the SMILE population and stratification by factor V Leiden (FVL) and by prothrombin 20210A mutation (PT20210A) carriership.

\begin{tabular}{|c|c|c|c|}
\hline Annexin A5 & N patients $(\%)$ & $\mathrm{N}$ controls $(\%)$ & Odds Ratio (95\% Cl) \\
\hline \multicolumn{4}{|c|}{ Total population } \\
\hline $\mathrm{CC}$ & $364(65.7)$ & $453(71.3)$ & 1 \\
\hline $\mathrm{CT}+\mathrm{TT}$ & $190(34.3)$ & $182(28.7)$ & $1.3(1.0-1.7)$ \\
\hline Total & 554 & 635 & \\
\hline \multicolumn{4}{|c|}{ No FVL (GG) } \\
\hline $\mathrm{CC}$ & $343(66.5)$ & $428(71.0)$ & 1 \\
\hline $\mathrm{CT}+\mathrm{TT}$ & $173(33.5)$ & $175(29.0)$ & $1.2(1.0-1.6)$ \\
\hline Total & 516 & 603 & \\
\hline \multicolumn{4}{|c|}{ No PT mutation (GG) } \\
\hline $\mathrm{CC}$ & $359(66.0)$ & $447(71.3)$ & 1 \\
\hline $\mathrm{CT}+\mathrm{TT}$ & $185(34.0)$ & $180(28.7)$ & $1.3(1.0-1.6)$ \\
\hline Total & 544 & 627 & \\
\hline \multicolumn{4}{|c|}{ FVL/PT20210A } \\
\hline $\mathrm{CC}$ & $26(54.2)$ & $30(77.0)$ & 1 \\
\hline $\mathrm{CT}+\mathrm{TT}$ & $22(45.8)$ & $9(23,0)$ & $2.8(1.1-7.2)$ \\
\hline Total & 48 & 39 & \\
\hline
\end{tabular}

Odds ratios, with $95 \%$ confidence interval of $C T+T T$ genotypes versus $C C$ genotype.

\section{DISCUSSION}

Annexin $\mathrm{A} 5$ is a $\mathrm{Ca}^{2+}$-dependent phospholipid binding protein that inhibits procoagulant reactions through its high affinity binding to phosphatidylserine containing membranes ${ }^{1}$ and its two-dimensional crystallization on the membrane surface ${ }^{13}$. Annexin A5 administered intravenously to animal models exhibits an antithrombotic activity likely based on the elucidated mechanism of anticoagulation $^{14}$. Altogether these findings suggest a role for annexin A5 in the antithrombotic arm of the haemostatic balance. Accordingly, genetically caused defect in the annexin A5 gene may be a genetic risk factor for thrombotic disorders. Therefore we screened for mutations in the annexin A5 gene in a population of patients with thrombosis. Our analysis revealed the presence of several mutations in the annexin A5 gene: one point mutation in the promoter 
region (T-907C), two point mutations (G-367A and G-296T) and an insertion in the untranslated exon $1(\mathrm{C}-368)$, one point mutation in the Kozak sequence located in exon $2(\mathrm{C}-1 \mathrm{~T})$, one point mutation in exon 11 (T771C) and two intronic mutations (A/G 23 bp $3^{\prime}$ in intron 5 and G/A 39 bp $3^{\prime}$ in intron 10). The $\mathrm{C}-1 \mathrm{~T}$ mutation is located in the Kozak sequence of the annexin $\mathrm{A} 5$ gene, and, hence, may alter transcription efficiency and, consequently, protein levels. The C-1T mutation was validated in two population-based case-control studies: the LETS and the SMILE study. Our analysis suggested a weak effect on the risk of myocardial infarction, in young men, where genetic risk factors may have stronger influence than environmental risk factors (odds ratio, 1.5, $\mathrm{Cl} 95=0.9-$ 2.4). In the presense of thrombophilia factors, factor $V$ Leiden or prothrombin $20210 \mathrm{~A}$ mutation, the annexin A5 variant was associated with a three-fold increased risk.

Whille we were conducting our studies, González-Conejero et al. reported the association of the $\mathrm{C}-1 \mathrm{~T}$ mutation with an increased risk. They postulated and showed supporting evidence that replacing $-1 \mathrm{C}$ by $\mathrm{T}$ in the Kozak sequence of the annexin A5 gene increased translation efficiency resulting in higher plasma levels of annexin A5 in T allele carriers ${ }^{6}$. Furthermore, they proposed that the higher circulating levels of free annexin A5 may protect against thrombosis by binding to prothrombotic, negatively charged phospholipids exposed on platelet surfaces during activation. They showed a two-fold reduced risk of myocardial infarction in young patients in the presence of the $T$ allele. However, the observed 1.6-fold increase in annexin A5 levels in plasma of $T$ allele carriers seems to be insufficient to explain the two-fold reduced risk to develop myocardial infarction. In fact the actual increase in plasma annexin A5 might be higher than reported by the authors. They measured annexin A5 in citrated plasma and it is known that the binding of annexin A5 to phospholipids is entirely reversible by removal of calcium by EDTA rather than with citrate ${ }^{15}$. Furthermore, van Heerde et al. recently reported significantly higher annexin A5 levels in EDTA plasma compared to citrated plasma ${ }^{16}$. Whether measurements in the plasma compartment do reflect the transcriptional activity of the annexin A5 gene needs to be further investigated.

Based on the findings of Kozak, who reported a slightly decrease in translation efficiency upon substituting the $C$ for a $T$ at position $-1^{8,17}$, and of van Heerde et al. ${ }^{16}$, who recently reported that annexin A5 levels are not elevated in plasma of $T$ allele carriers compared to $C$ allele carriers, we hypothesize that a decrease in translation efficiency of the annexin A5 gene of T allele carriers results in an insufficient shielding of the negatively charged phospholipids creating a more 
prothrombotic surface. In combination with factor $V$ Leiden or the prothrombin $20210 \mathrm{~A}$ mutation, this leads to an even more hypercoagulable state.

The advantage of the LETS and SMILE study is their size which allows stratification. However, stratification results in a smaller number of individuals, which can lead to associations arising by chance. Furthermore, in this study we could not determine annexin A.5 plasma levels in $C$ allele carriers versus $T$ allele carriers due to the absence of EDTA plasma.

We can conclude that the C-1T mutation in the annexin A5 gene plays no role in the etiology of venous thrombosis but may be associated with an increased risk for myocardial infarction, especially in young men and in combination with coagulation defects such as factor $V$ Leiden and the prothrombin $20210 \mathrm{~A}$ mutation.

\section{ACKNOWLEDGMENTS}

We thank Thea Visser for drawing blood samples and Petra Noordijk for performing the DNA analysis and Ank Schreijer for secretarial support for both the 'Leiden Thrombophilia Study' and 'Study of Myocardial Infarction Leiden'. We thank Karly Hamulyak for providing the samples for the indentification study. We also express our gratitude to all individuals who participated in the 'Leiden Thrombophilia Study' and 'Study of Myocardial Infarction Leiden'. This Research was supported by the Netherlands Heart Foundation Grant no 96.025, Grant no. 92.345 for the SMILE study and Grant no. 89.063 for the LETS study. 


\section{REFERENCES}

1. van Heerde $W L$, de Groot $P G_{8}$ Reutelingsperger $C P$, The complexity of the phospholipid binding protein Annexin V. Thromb Haemost, 1995; 73: 172-179.

2. Rand $\mathrm{JH}_{\text {, Wu }} \mathrm{XX}$, Andree $\mathrm{HA}_{\mathrm{a}}$ Lockwood $\mathrm{CJ}$, Guller $\mathrm{S}$, Scher J, Harpel $\mathrm{PC}$, Preginancy loss in the antiphospholipid-antibady syndrome-a possible thrombogenic mechanism. N Engl J Med, 1997; 337: 154-160.

3. Rand $J H$, Wu XX, Andree HA, Ross JB, Rusinova E, Gascon-Lema MG, Calandri C, Harpel PC, Antiphospholipid antibodies accelerate plasma coagulation by inhibiting annexin- $V$ binding to phospholipids: a "lupus procoagulant" phenomenon. Blood, 1998; 92: 1652-1660.

4. Tait JF, Frankenberry $D A$, Shiang $R$, Murray $J C$, Adler DA, Disteche $C M$, Chromosomal localization of the human gene for annexin $V$ (placental anticoagulant protein I) to 4q26---q28. Cytogenet Cell Genet, 1991; 57: 187-192.

5. Fernandez MP, Morgan RO, Fernandez MR, Carcedo MT, The gene encoding thuman annexin $V$ has a TATA-less promoter with a high $\mathrm{G}+\mathrm{C}$ content. Gene, 1994; 149: 253-260.

6. Gonzalez-Conejero R, Corral J, Roldan V, Martinez C, Marin F, Rivera J, Iniesta $J A$, Lozano ML, Marco $P$, Vicente $V, A$ common polymorphism in the annexin $V$ Kozak sequence $(-1 C>T)$ increases translation efficiency and plasma levels of annexin $\mathrm{V}$, and decreases the risk of myocardial infarction in young patients. Blood, 2002; 100: 2081-2086.

7. Kozak $M$, Point mutations define a sequence flanking the AUG initiator codon that modulates translation by eukaryotic ribosomes. Cell, 1986; 44: 283-292.

8. Kozak $M$. At least six nucleotides preceding the AUG initiator codon enhance translation in mammalian cells. J Mol Biol, 1987; 196: 947-950.

9. Rosendaal FR, Koster T, Vandenbroucke JP, Reitsma PH, High risk of thrombosis in patients homozygous for factor $V$ Leiden (activated protein $\mathrm{C}$ resistance). Blood, 1995; 85: 1504-1508.

10. Doggen $\mathrm{CJ}$, Cats $V \mathrm{M}_{\text {, Bertina }} \mathrm{RM}_{\mathrm{s}}$ Rosendaal $F R$ interaction of coagulation defects and cardiovascular risk factors: increased risk of myocardial infarction associated with factor $V$ Leiden or prothrombin 20210A. Circulation, 1998; 97 : $1037-1041$

11. Miller SA, Dykes DD, Polesky HF, A simple salting out procedure for extracting DNA from human nucleated cells. Nucleic Acids Res, 1988; 16: 1215.

12. Woolf $\mathrm{B}$, On estimating the relation between blood group and disease. Ann Hum Genet, 1955; 19: 251-253.

13. Oling $F$, Bergsma-Schutter $W$, Birisson $A$, Trimers, dimers of trimers, and trimers of trimers are common building blocks of annexin a5 two-dimensional crystals. I Struct Biol, 2001; 133: 55-63.

14. Romisch $J$, Seiffge $D$, Reiner $G$. Paques EP, Heimburger $N$, In-vivo antithrombotic potency of placenta protein 4 (annexin V). Thromb Res, 1991; 61: 93-104.

15. Andree $H A$, Reutelingsperger $C P$, Hauptmann $R$, Hemker HC, Hermens WT, Willems GM, Binding of vascular anticoagulant alpha (VAC alpha) to planar phospholipid bilayers. J Biol Chem, 1990; 265: 4923-4928.

16. Van Heerde WL, Kenis $H$, Schoormans $S$, Lap $P$, Reutelingsperger $C P$, GonzalezConejero R, Corral J, Roldan V, Martinez C, Marin F, Rivera J, Iniesta JA, Lozano 
$M L$, Marco $P$, Vicente $V$. The $-1 C>T$ mutation in the annexin $A 5$ gene does not affect plasma levels of annexin A5. Blood, 2003; 101: 4223-4224.

17. Kozak M, Pushing the limits of the scanning mechanism for initiation of translation. Gene, 2002; 299: 1-34. 


\section{CHAPTER 3}

\section{REVERSIBILITY OF PHOSPHATIDYLSERINE EXTERNALIZATION AND APOPTOSIS IN THE ISCHEMIC HEART}

${ }^{1}$ Heidi Kenis, "Leo Hofstra, "Ewald Dumont, "Nicole Bitsch, "Abdel Bennaghmouch, ${ }^{2}$ Nezam Haider, ${ }^{1}$ Hein Wellens, ${ }^{2}$ Jagat Narula and ${ }^{1}$ Chris Reutelingsperger

1 Cardiovascular Research Institute Maastricht, Maastricht, the Netherlands

2 University of California Irvine, Irvine, CA, USA

Submitted for publication to Circulation Research 


\section{ABSTRACT}

INTRODUCTION: Recently, we reported that annexin A5 mediates the internalization of phosphatidylserine (PS) - expressing membrane patches in vitro. In preliminary data, we and others also found that PS externalization in the heart occurs in vivo after a brief episode of ischemia without subsequent development of apoptosis (Narula $\mathrm{J}$ and Dumont $\mathrm{E}$ unpublished data). Here, we aimed to investigate whether annexin A5 internalization occurs in the heart in vivo, which could provide the opportunity to use annexin A5 as a cell entry and/or drug targeting tool in vivo in cardiac cells.

METHODS: Induction of apoptosis in response to brief episodes of ischemia was evaluated by annexin A5 based detection of PS expression on the cardiomyocyte surface in the murine ischemia-reperfusion model.

RESULTS: We show that cardiomyocytes express PS at their surface following an insult of 5 minutes of ischemia. PS expression persists for at least 24 hours following ischemia, decreases after 48 hours and is lost 7 days after the onset of ischemia, indicating a transient exposure of PS. PS externalization was secondary to activation of caspase 3 , and could be prevented by systemic administration of a pan-caspase inhibitor, zVAD-fmk. Necrosis was not observed in the ischemic region. Microscopic analysis revealed intracellular vesicles containing annexin $A 5$.

CONCLUSION: This transient PS exposure allows annexin A5 to bind to PSpositive cardiomyocytes and to mediate its own internalization and accumulation into cytoplasmic vesicles. Our data indicate that cardiomyocytes initiate the apoptotic cascade following brief episodes of ischemia resulting in a transient exposure of PS. Thus allows for the development of novel therapeutic interventions using annexin A5 as a cell entry and/or drug targeting tool, including gene therapy. 


\section{INTRODUCTION}

Apoptosis, also called programmed cell death, is characterized by a sequence of morphological alterations ${ }^{\prime}$. Following activation of the cell death program, the cell shrinks, the plasma membrane blebs and the nucleus condensates and fragmentates. The biochemistry underlying these morphological changes depends on the activation of caspases resulting in a proteolytic burst within the cell leading to the release of cytochrome $c$ from the mitochondria and activation of the executioner caspase, caspase $3^{2}$. Two distinctive features of apoptosis which occur at the cell membrane level, are blebbing of the plasma cell membrane and the externalization of a membrane phospholipid, phosphatidylserine (PS) ${ }^{3}$. In a viable cell, PS is only present at the inner leaflet of the plasma cell membrane, due to the active transport by the membrane protein translocase ${ }^{4}$. However, after initiation of the cell death program, leading to activation of the so-called executioner caspases, inhibition of translocase accurs. Furthermore, transmembrane proteins called scramblase and floppase are activated, resulting in rapid externalization of PS. Annexin A5, a $35.8 \mathrm{kDa}$ plasma protein has high affinity for PS, and is now widely used for the detection of apoptotic cell death, in vitro and in vivo ${ }^{5-10}$.

In a recent report, we demonstrated that annexin A5 not only binds to apoptotic cells, but also mediates the internalization of PS-positive membrane patches ${ }^{11}$. It was found that the membrane internalization depends on the $2 \mathrm{D}$ crystallization of annexin A5 molecules that have bound to the PS-positive cell membrane surface. Furthermore, it was observed that the internalization of PS positive membrane patches results in the formation of vesicles, which are being transported into the cytosol in a cytoskeleton-dependent way. In a subsequent report, we observed that the annexin A5-mediated internalization of PS. expressing membrane patches downregulates proteins embedded in this membrane patch such as tissue factor ${ }^{12}$. This novel portal of entry into cells may have important implications for the intracellular delivery of drugs.

In preliminary data, we and others have reported that PS externalization in the heart occurs in vivo after a brief episode of ischemia ${ }^{13}$. However, no apoptotic cell death was observed after histological analysis of the cardiac tissue. These data indicate that PS externalization may occur in the heart upon minor injury, but does not lead to cell death. This finding is intriguing, since the exposure of PS may provide an opportunity for annexin A5-mediated targeting of drugs and/ar genes in the heart in vivo. However, it is unknown whether annexin A5mediated internalization of PS positive membrane pattches also occurs in vivo in 
the heart and, whether this could be used as a portal of entry for the delivery of drugs and/or genes. In addition, the time frame and extent of PS exposure following brief episodes of ischemia remain to be defined.

To address these questions, we used an optical imaging system to detect apoptosis in mouse using fluorescently labeled annexin $\mathrm{A} 5^{6}$. This annexin A5based imaging technique allows us to study PS exposure, the time frame and extent of PS exposure and whether the annexin A5-dependent internalization also occurs in vivo after brief episodes of ischemia in the mice ischemia/reperfusion ( $(/ / R)$ model.

Our data show extensive PS exposure which least for 24 hours, substantially decreases after 48 hours and is lost 7 days after the onset of ischemia. Furthermore, we observed PS-dependent internalization of annexin A5 in vivo in cardiomyocytes.

\section{METHODS}

\section{PREPARATION OF ANNEXIN-A5 PROBES FOR IN VIVO USE}

Human annexin A5 was produced by expression in Escherichia coli as previously described ${ }^{14}$. The recombinant annexin A5 retains its PS-binding activity equivalent to that of native annexin A5. The annexin A5 mutant M1234 (E72D, D144N, E228A and D303N) having four defective calcium binding sites was kindly provided by Prof. Dr. F. Russo-Marie (BIONEXISPharmaceuticals) ${ }^{15}$. The annexin A5 mutant M23 was generated by subcloning the mutations D144N and E228A into the annexin A5 cDNA. annexin A5, M23 and M1234 were labeled with FITC, Oregon Green or Alexa568succinimidylester according to the manufacturers'protocol (Molecular Probes). The labeled proteins with 1:1 stoichiometry were purified from the mixtures by MonoQ chromatography with Äcta Explorer (Amersham-Pharmacia).

\section{SURGICAL INDUCTION OF BRIEF ISCHEMIA IN MICE}

Induction of ischemia was performed as described previously ${ }^{6}$. After left thoracotomy and exposure of the heart, the left anterior descending coronary artery in mice was ligated for $5 \mathrm{~min}$ and subsequently reperfused ${ }^{16}$. The ischemia and reperfusion intervals were represented as $\mathrm{l} / \mathrm{R}$ cycles in minutes. Reperfusion was ensured for 30,90, 180 and 360 minutes, and 24, 48, $72 \mathrm{hrs}$ and 7 days in mice. For positive control, ischemia was induced for 30 minutes with reperfusion for 90 minutes that results in overt myocardial infarction. Fluorescently labeled annexin A5 (annexin A5-Alexa568 or annexin A5-Oregon 
Green) was intravenously administered to mice. The data were collected for 3 mice in each designated group, including I/R 5/30,5/90,5/180,5/360 minutes, $5 / 24 \mathrm{~h}, 5 / 48 \mathrm{~h}, 5 / 72 \mathrm{~h}$ and $5 / 7$ days combinations. All the combination groups were duplicated for annexin A5 administration at 20 minutes before the end of the reperfusion episode and sacrificed. The hearts were analyzed ex vivo by fluorescence microscopy.

To evaluate the possibility of continued PS exposure, annexin A5-Alexa568 (1.8 $\mathrm{mg} / \mathrm{kg}$ ) was injected just after coronary artery occlusion, followed by the injection of annexin A5-Oregon Green (1.8 mg/kg) $10 \mathrm{~min}-20 \mathrm{~min}$ respectively before the end of the reperfusion episode. The hearts were flushed with $4 \%$ paraformaldehyde in Apoptest binding buffer, removed and analyzed ex vivo by fluorescence microscopy. To demonstrate that the $2 \mathrm{D}$-crystallization of annexin A5 on the surface is the driving force for the internalization, a mutant of annexin A5 M23-Alexa568, which binds to PS but does not induce its own internalization, was injected prior to coronary artery occlusion. The hearts were removed and analyzed ex vivo by fluorescence microscopy. To test whether the internalization of annexin A5 is PS-dependent, a mutant of annexin A5 M1234Alexa568, which does not bind to PS, was injected prior to coronary artery occlusion. The hearts were removed and analyzed ex vivo by fluorescence microscopy.

\section{RESULTS}

PS EXPOSURE AFTER BRIEF MYOCARDIAL ISCHEMIA.

In preliminary data, we and others have reported that PS externalization in the heart occurs in vivo after a brief episode of ischemia ${ }^{13}$. However, the time frame of PS exposure following brief episodes of ischemia remains to be defined. A novel myocardial ischemia-reperfusion model in the beating mouse heart was used $^{5}$. In the first experiments, LAD coronary artery was occluded to induce 5minute episode of ischemia ( $1-5)$, followed by 90 minutes of reperfusion (R-90), and fluorescently labeled annexin A5 (annexin A5-Alexa568) was intravenously administered 10 minutes before completion of reperfusion to identify apoptotic myocytes ${ }^{17}$. Abundant annexin A5 positive cardiomyocytes were observed in the ischemic area of the hearts (Fig. 1A (i)). The binding of annexin A5 to the plasma cell membrane of cardiomyocytes indicated that PS was externalized and that the cell death program was activated ${ }^{3,18}$. To determine the length of persistence of PS exposure after brief episode of ischemia, we subjected mouse hearts in vivo to 5 -minute ischemia followed by 180 minute (I-5/R-180), 
360 minute (I-5/R-360), or 24 hours (I-5/R-24h) reperfusion. Annexin A5, injected 10 minutes before completion of reperfusion showed binding to the plasma membrane of numerous cardiomyocytes in the heart in $1-5 / R-180,1-5 / R$ 360 and I-5/R-24h groups (Fig. 1A (ii-iv)). These data indicate that PS exposed by a brief ischemic episode, persists for at least 24 hours after the insult. Histophatological data showed that neither apoptosis nor necrosis did occur up to 24 hours (data not shown), even in the annexin A5 positive cardiomyocytes.

A
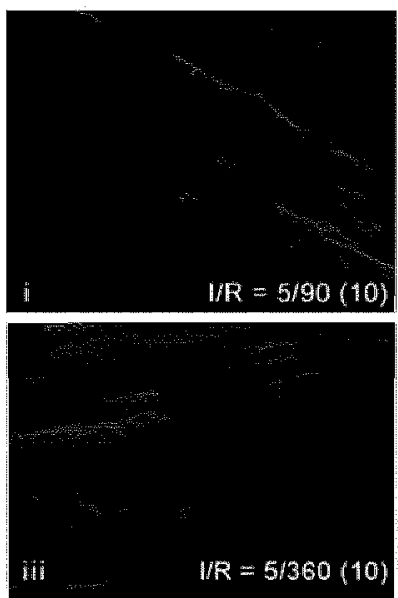

B
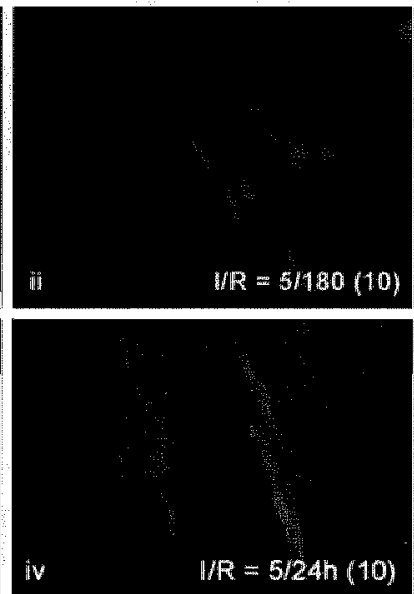

p17.

p12.

if

FIG. 1. (A) PS exposed by a brief ischemic episode persists at least 24 hours after the insult. (i) In the first set of experiments mice were sacrificed after 5-minute ischemia and 90-minute reperfusion and fluorescently labeled annexin-A5 (annexin A5-Alexa568) was injected 10 minutes before sacrifice [I-5/R-90(10)]. (ii-iv) demonstrate reperfusion for 180,360 minutes and 24 hours, respectively, with annexin A5-Alexa568 injected 10 minutes before sacrifice $[1-5 / R-180(10), \quad$ I-5/R-360(10), I-5/R-24h(10)]; annexin-A5 binding continues to be localized to the cell membrane. (B) Caspase inhibition prevents PS exposure upon brief ischemia. In the ischemia-reperfusion model similar to $A$, instant activation of caspase 3 is seen in the ischemic region. The first lane of the Western blot represents reperfused ischemic myocardium and lane 2 represents the normal myocardium; no caspase activation is seen in the non-infarcted myocardium. These data are confirmed using densitometry.

Apoptosis assays in vitro have shown that PS exposure is downstream of critical events in the cell death program such as the activation of caspase 3 and release of cytochrome $c$ from mitochondria ${ }^{19 .} 20$. To determine whether PS 
exposure after brief episodes of ischemia is a caspase-dependent process, we performed an immunoblot of caspase 3 in I-5/R-90 hearts. The presence of 12 and $17 \mathrm{kDa}$ split active fragments of caspase 3 , indicated activation of caspase 3 ; densitometric analysis confirmed a 4-fold increase in activation of caspase 3 (Fig. 1B). To further investigate the involvement of caspase activation in PS exposure, mice subjected to brief cardiac ischemia received a pancaspase inhibitor, zVAD-fmk, before coronary occlusion. In these experiments (1-5/R-90) annexin $A 5$, uptake was not seen in the ischemic zone (data not shown).

A
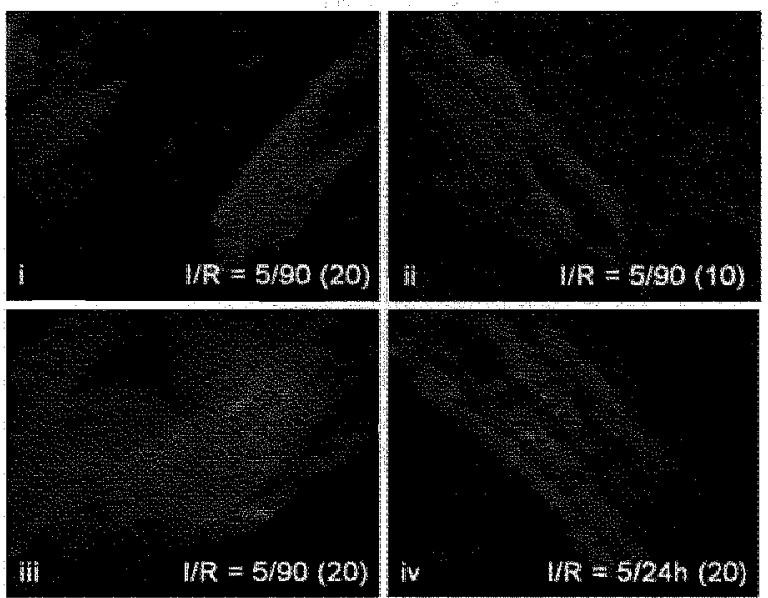

FIG. 2. Following brief ischemia, bound annexin $A 5$ is internalized into cytoplasmic vesicles. (A) (i) Administration of annexin A5-Alexa568 20 minutes before sacrifice in the 5-minute ischemia and 90-minute reperfusion model demonstrates its localization intracellularly, whereas administration of annexin A5-Alexa568 10 minutes before sacrifice demonstrated binding to the cell membrane surface [see Fig. $1 \mathrm{~A}$ (i)], (ii) Ex vivo image of the heart of a mouse show the binding and uptake of annexin A5-Alexa568 administered in the beginning of the reperfusion episode, but only binding and no uptake of annexin-A5 Oregon Green administered $10 \mathrm{~min}$ before sacrifice, whereas (iii) show binding and uptake of annexin A5-Alexa568 administered in the beginning of the reperfusion episode and uptake of annexin A5-Oregon-Green administered 20 minutes before sacrifice. (iv) Ex vivo image of the heart in the 5-minute ischemia and 24-hours reperfusion model show the binding and massive uptake of annexin A5-Alexa568 administered in the beginning of the reperfusion episode, but also binding and uptake of annexin A5-Oregon Green administered 20 min before sacrifice. 
The above experiments indicated that PS externalization during ischemic injury is mediated by activation of caspases. Although PS exposure and caspase 3 activation represent commitment of the cell to programmed death ${ }^{19,20}$, our data indicate that cardiomyocytes recover from activation of caspases and PS exposure if reperfusion is restored early.

\section{INTERNALIZATION OF PS BOUND ANNEXIN A5 IS A CONTINUOUS PROCESS THAT OCCURS IN VIVO IN CARDIOMYOCYTES.}

On basis of our previous in vitro data, that annexin A5 mediates the internalization of PS-positive membrane patches ${ }^{11}$, we investigated whether this process of PS-dependent internalization mediated by annexin A5 also occurs in vivo in the ischemia/reperfused injured heart.

Therefore, we injected annexin $A 5$ at different time points before the end of the reperfusion episode in the $1-5 / R-90$ model. Annexin A5 injected 10 minutes before sacrifice of the mouse hearts shows binding almost exclusively to cardiomyocyte membranes (Fig. 1A (i)). However, injection of fluorescently labeled annexin A5 $20 \mathrm{~min}$ before completion of reperfusion showed localization of annexin A5 within the cytoplasmic compartment of the cell (Fig. 2A (i)). This indicates that the PS-annexin A5 complex is internalized within approximately 10-20 minutes after annexin A5 binding. The question still remains whether the internalization of PS bound annexin A5 is a one time event or is a continuous process during the injury and recovery phase $\mathrm{e}^{21,22}$. To distinguish between the two processes, annexin A5-Alexa568 was injected in the beginning of the reperfusion episode and annexin A5-Oregon Green was injected either $10 \mathrm{~min}$ $(1-5 / R-90 / 10)$ or $20 \mathrm{~min}(1-5 / \mathrm{R}-90 / 20)$ before the end of the reperfusion episode in the 1-5/R-90 model. The I-5/R-90/10 experiment showed the presence of annexin A5-Alexa568 within the cardiomyocytes and only binding of annexin A5-Oregon Green to the surface of the cardiomyocytes (Fig. 2A (ii)). In the I5/R-90/20 experiment, both annexin A5-Alexa568 and annexin A5-Oregon Green were present within the cardiomyocytes (Fig. 2A (iii)). This suggests that the internalization of PS bound annexin A5 occurs continuously for at least 90 minutes and is not a one time event that only occurs just after reperfusion.

To study the kinetics of continuous annexin A5 internalization, annexin A5Oregon Green was injected in the beginning of the reperfusion episode and annexin A5-Alexa568 was injected 20 min before the end of the reperfusion episode in the I-5/R-24h model (Fig 2A (iv)). These data showed massive accumulation of annexin A5-Oregon Green within the cardiomyocytes as well as internalization of annexin A5-Alexa568. 
Taken together, these in vivo data indicate that annexin A5 is internalized in vivo in cardiomyocytes within $20 \mathrm{~min}$ after annexin A5 binding and that the internalization of annexin A5 is a continuous process which lasts at least for 24 hours and results in the accumulation of cytoplasmic vesicles containing annexin A5. These data may provide an opportunity for annexin A5-mediated targeting of drugs and/or genes into the cardiac cells.

\section{PS EXPOSURE IS A TRANSIENT PROCESS.}

Our data show that PS-bound annexin A5 is continuously internalized into cardiomyocytes. However, the dynamics and time frame of PS exposure is not known. To study dynamics of PS exposure, we employed a dual probe approach using annexin A5-Oregon Green $\left(\lambda_{e x}=488, \lambda_{\text {em }}=520\right)$ and annexin A5-Alexa568 $\left(\lambda_{\mathrm{ex}}=568, \lambda_{\mathrm{em}}=+/-600\right)$. We injected one of the fluorochromes in the beginning of the reperfusion and the other annexin A5 fluorochrome 10 min before sacrifice in the 1-5/R-24h, 1-5/R-48h, 1-5/R-72h, 1-5/R-7days experiments (Fig. 3A (i-iv)). A high uptake of annexin A5-Oregon Green as well as annexin A5-Alexa568 was seen after $24 \mathrm{~h}$ (Fig. 3A (i)). We observed a substantial decrease in the uptake of annexin A5-Alexa568 after 48 hours of reperfusion in the area at risk and no uptake of annexin A5-Oregon Green (Fig. 3A (ii)). After 72 hours of reperfusion, almost no annexin A5-Alexa568 and annexin A5-Oregon Green was observed (Fig. 3A (iii)) and after 7 days of reperfusion, neither annexin A5-Alexa568 nor annexin A5-Oregon Green was taken up by the cardiomyocytes (Fig. 3A (iv)). These data indicate that PS exposure after brief myocardial infarction is a transient process that reaches a maximum at 24 hours after reperfusion and substantially decreases after 24 hours. These data provide essential information about the time window for the use of annexin A5 as a cell entry mediator. Annexin A5 mediated targeting of drugs and/or genes into cardiac cells is optimal in the first 24 hours after reperfusion. 
A
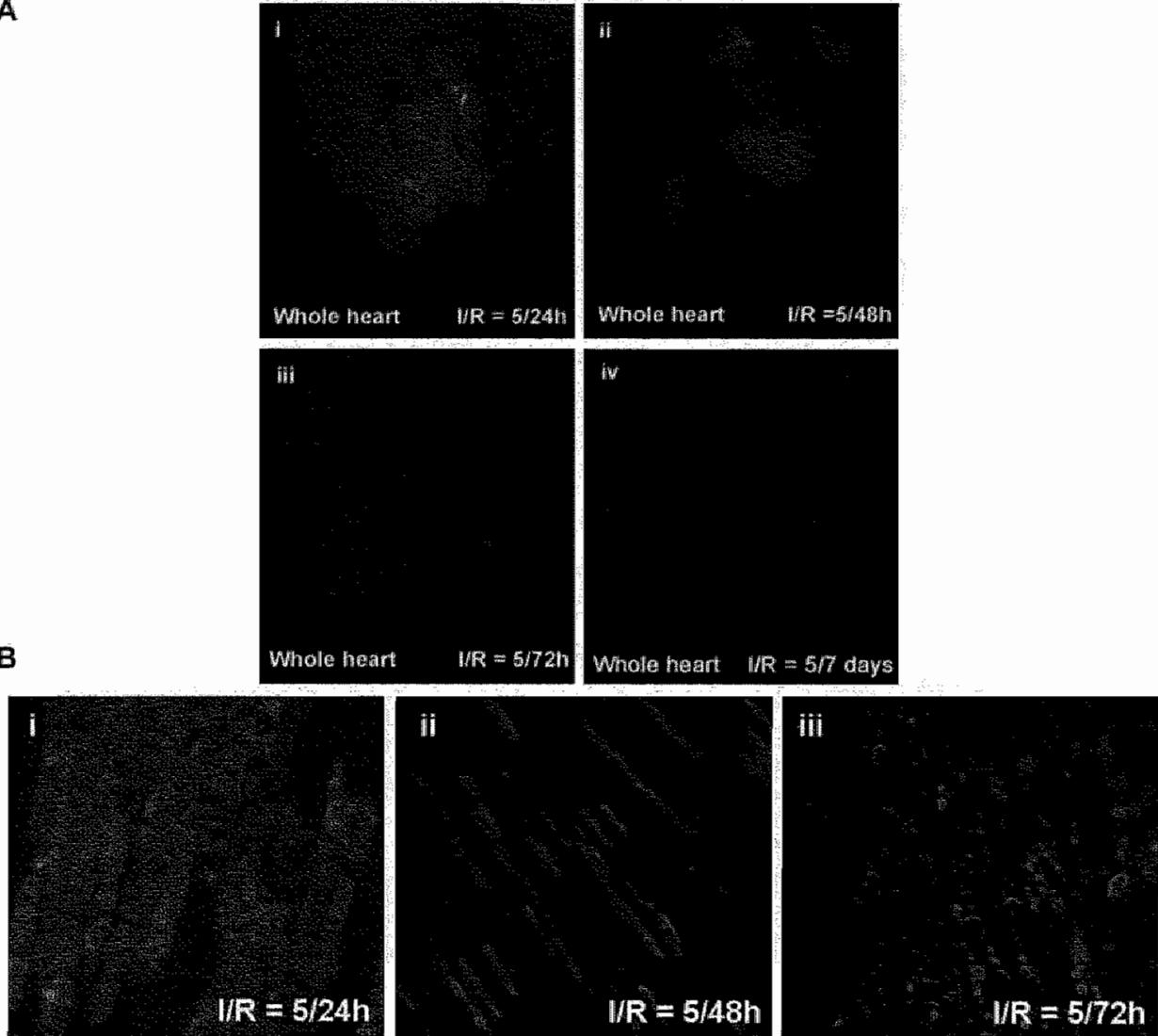

FIG. 3. PS exposure is a transient process. (A) (i) Ex vivo image of the whole heart of a mouse injected with annexin A5-Oregon Green in the beginning of the reperfusion episode and annexin A5-Alexa568 $10 \mathrm{~min}$ before sacrifice in the 1-5/R-24h experiment. (ii-iv) Ex vivo image of the whole heart of a mouse injected with annexin A5-Alexa568 in the beginning of the reperfusion episode and annexin A5-Oregon Green 10 min before sacrifice in the 1-5/R-48h, I-5/R-72h and I-5/R-7days experiment. (B) (i-iii) The same hearts were analyzed under higher magnification (100x).

\section{D-CRYSTALLIZATION IS THE DRIVING FORCE FOR THE PS-DEPENDENT INTERNALIZATION OF ANNEXIN A5 IN VIVO IN CARDIOMYOCYTES.}

On basis of our previous in vitro data, that annexin A5 mediates the internalization of PS-positive membrane patches ${ }^{11}$, we investigate whether this process of PS-dependent internalization is also driven by the 2D-crystallization of annexin A5 on the cell membrane surface. In order to test this, we generated 
the annexin $\mathrm{A} 5$ mutant $\mathrm{M} 23$, which, by prediction from the avallable structural data $^{23,24}$, binds to PS but lacks the ability to crystallize on the PS-expressing membrane surface. M23-Alexa568 was injected in the beginning of the reperfusion episode in the 5-minute ischemia and 90-minute reperfusion model. The mutant M23 binds to the sarcolemma of the cardiomyocytes but does not induce its own internalization (Fig. 4A (i)), indicating that the 2D-crystallization is also the divining force for the internalization in vivo. Furthermore, to test whether this PS-dependent process of internalization occurs also in wivo, we generated the annexin A5 mutant M1234, which lacks the ability to bind to PS. M1234FITC was injected in the beginning of the reperfusion episode in the 5-minute ischemia and 90-minute reperfusion model. The mutant M1234 does not bind to cardiomyocytes (Fig. 4A (ii)), indicating that the internalization is PS-dependent and occurs also in vivo.

A

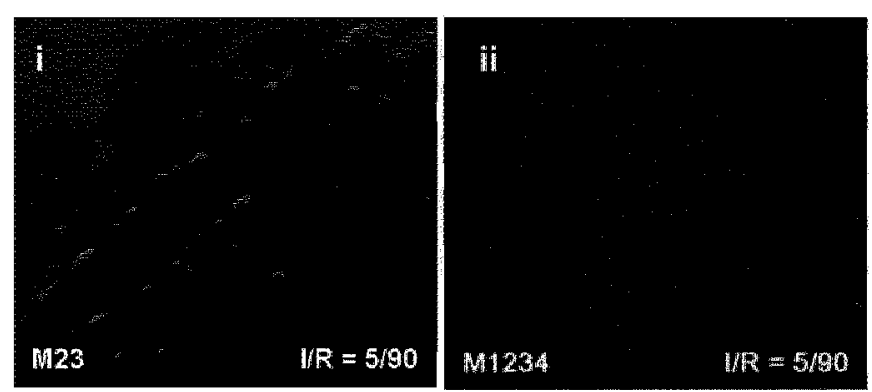

FIG. 4. 2D-crystallization is the driving force for the PS-dependent intermalization of annexin $A 5$ in wivo in cardiomyocytes. (A) (i) Ex vivo image of the heart of a mouse injected with M23-Alexa568 prior to 5-minute ischemia and 90-minute reperfusion demonstrates binding to the cell membrane surface. (ii) Ex vivo image of the heart of a mouse injected with M1234-Alexa568 prior to 5-minute ischemia and 90-minute reperfusion shows no binding to the cell membrane surface.

\section{DISCUSSION}

Our data show a considerable uptake of annexin A5 in the affected region of the heart 24 hours after a brief episode of ischemia and the uptake of annexin A5 substantially decreases after 48 hours and is almost lost after 72 hours. No uptake was observed 7 days after the onset of ischemia. Further, we observed not only binding of annexin A5 to the sarcolemma of the cardiomyocytes but also internalization of annexin A5 into cytoplasmic vesicles. 
In preliminary data, we and others have reported that PS externalization in the heart occurs in vivo after a brief episode of ischemia. However, no apoptotic cell death was observed after histological analysis of the cardiac tissue. This would imply either that the PS exposed cells are recovering from apoptosis or that the cells have been removed by phagocytes. The reversal of apoptosis has been reported previously in $C$. elegans ${ }^{25,26}$. During developmental apoptosis, engulfment genes act in concert with CED-3, the C. Elegans homologue of caspase 3 , in cells destined to die in the anterior pharynx. In the absence of activation of the engulfment machinery, such cells showed all the features of apoptosis, but cell death did not occur; these cells recover completely and remain viable thereafter. Our data show a massive and caspase 3-dependent uptake of annexin A5 24 hours after ischemia and a substantial decrease after 48 hours. This transient exposure of PS with subsequent uptake of annexin A5 confirms that mammalian cells can recover from apoptosis, despite activation of one of the key executioner caspases, caspase 3. These data imply that PS expression is a transient process while the annexin A5-induced internalization is a continuous process, which may continue to occur untill activated caspase 3 is no longer present in the cell. Once caspase 3 is not active anymore, we believe that there are mechanisms, which result in the recovery from apoptosis as observed by the transient exposure of PS.

Other examples of PS exposure not associated with execution of apoptosis include activation of $\mathrm{B}$ cell lymphoma cells, which in response to cross-linking of the membrane immunoglobulin receptor stained positive for annexin $\mathrm{A} 5$, but were able to restore their phospholipid asymmetry and resume growth upon withdrawal of the stimulus ${ }^{27}$.

The other explanation for the observed absence of apoptotic or necrotic cells in the area at risk could be that the cells have been removed by phagocytes. The latter does not seems to be the case, since no infiltration of inflammatory cells was seen after 48 hours. However, after 72 hours we observed a few inflammatory cells which were annexin A5 positive. Based on these observations, we believe that most of the annexin A5 internalized cardiomyocytes recover in the early phase of apoptosis and that only a small amount of PS-exposing cells are cleared by phagocytes.

Untill now, it was believed that the binding of annexin A5 to externalized PS offers the cells protection from being recognized by professional phagocytes, since externalized PS is necessary for engulfment of apoptotic cells and serves as an "eat me" signal ${ }^{21}$. However, our recent in vitro findings showed that the 
annexin A5 internalized cells still expose PS at their surface but were less recognized by phagocytes (see Chapter $5, \mathrm{Fig}$. 3f). These data indicated that not only shielding PS but internalization of PS-expressing membrane patches which probably harbors a complex collection of "eat me" signals may protect the cells from being recognized by phagocytes. Recent clinical studies have shown that plasma annexin A5 levels are elevated in patients with acute myocardial infarction ${ }^{28}$. These data suggest that annexin A5 may serve as an acute phase reactant, which may save cells that are susceptible to engulfment.

Recently, we reported that annexin A5 opens a novel portal of cell entry by binding to PS expressing membranes ${ }^{11}$. In this paper, we demonstrate that annexin A5 activates the novel pinocytic pathway also in wivo in cardiomyocytes. This novel portal of entry into cells may have important implications for use of annexin A5 not only as a diagnostic tool but also as a drug carrier and cell entry mediator. If translated to the clinical setting, a patient with short-term ischemia may have temporary PS exposure in the heart. This PS exposure can be visualized using ${ }^{99 \mathrm{~m}} \mathrm{Tc}$-labeled annexin A5 but can also be used as a therapeutic tool to deliver cardio-protective agents to the PS-positive cardiomyocytes. Furthermore, transient PS exposure which reaches a maximum at 24 hours after reperfusion gives us an indication of the time window for the diagnostic and therapeutic use of annexin A5.

In conclusion, our data demonstrate that caspase 3 is activated and that PS externalization persists at least for 24 hours in cardiomyocytes, decreases substantially after 48 hours and is almost lost after 72 hours in response to brief ischemia of the heart. This transient exposure of PS by cardiomyocytes upon early restoration of blood flow may be exploited not only for diagnostic imaging but also for therapeutic purposes due to the internalization of annexin A5 into the cardiomyocytes. However, the biological role of annexin A5 internalization remains to be understood. 


\section{ACKNOWLEDGMENTS}

Ewald A. Dumont was a DiPaima fellow and supported by DiPalma-Brodsky Research

Funds to Dr. Narula, Leo Hofistra is Clinical Investigor of Dutch Heart Foundation (NHS2000-D35) and the Dutch Science Foundation (NWO program grant 2002). Supported in part the by Dutch Heart Foundation Grants 98.195 and Wynand Pon Foundation.

\section{REFERENCES}

1. Kerr JF, Wyllie $A H$, Currie $A R$, Apoptosis: a basic biological phenomenon with wide-ranging implications in tissue kinetics. $\mathrm{Br} J$ Cancer, 1972; 26: 239-257.

2. Rosse $T$, Olivier R, Monney $L$, Rager M, Conus $S$, Fellay I, Jansen B, Borner $C$, Bcl-2 prolongs cell survival after Bax-induced release of cytochrome c. Nature, 1998; 391: 496-499.

3. Fadok VA, Voelker DR, Campbell PA, Cohen JJ, Bratton DL, Henson PM, Exposure of phosphatidylserine on the surface of apoptotic lymphocytes triggers specific recognition and removal by macrophages. I immunol, 1992; 148: 22072216.

4. Zwaal RF, Schroit AJ, Pathophysiologic implications of membrane phospholipid asymmetry in blood cells. Blood, 1997; 89: 1121-1132.

5. Dumont EA, Hofstra $L$, van Heerde WL, van den Eijnde $S$, Doevendans PA, DeMuinck E, Daemen MA, Smits JF, Frederik $P$, Wellens HJ, Daemen MJ, Reutelingsperger CP. Cardiomyocyte death induced by myocardial ischemia and reperfusion: measurement with recombinant human annexin- $V$ in a mouse model. Circulation, 2000; 102: 1564-1568.

6. Dumont EA, Reutelingsperger CP. Smits JF, Daemen MU, Doevendans PA, Wellens HJ, Hofstra L, Real-time imaging of apoptotic cell-membrane changes at the single-cell level in the beating murine heart. Nat Med, 2001; 7: 1352-1355.

7. Hofstra L, Dumont EA. Thimister PW, Heidendal GA, DeBruine AP, Elenbaas TW, Boersma HH, van Heerde WL, Reutelingsperger $\mathrm{CP}$, In vivo detection of apoptosis in an intracardiac tumor. Jama, 2001; 285: 1841-1842.

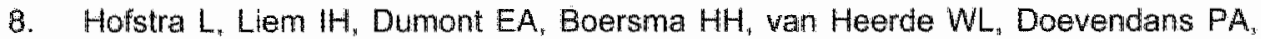
De Muinck $E$, Wellens $H J$, Kemerink $G J$, Reutelingsperger GP. Heidendal GA, Visualisation of cell death in vivo in patients with acute myocardial infarction. Lancet, 2000; 356: 209-212.

9. Vriens PW, Blankenberg FG, Stoot JH, Ohtsuki K, Berry GJ, Tait JF, Strauss HW. Robbins RC. The use of technetium Tc $99 \mathrm{~m}$ annexin $\mathrm{V}$ for in vivo imaging of apoptosis during cardiac allograft rejection. J Thorac Cardiovasc Surg, 1998; 116 : 844-853. 
10. Blankenberg FG, Katsikis PD, Tait JF, Davis RE, Naumovski $L$, Ohtsuki $K$, Kopiwoda S, Abrams MJ, Strauss HW, Imaging of apoptosis (programmed cell death) with $99 \mathrm{mTC}$ annexin V. J Nucl Med, 1999; 40: 184-191.

11. Kenis $H$, van Genderen $H$, Bennaghmouch $A$, Rinia HA, Frederik $P$. Narula J, Hofstra $L$, Reutelingsperger CP. Cell surface-expressed phosphatidylserine and annexin A5 open a novel portal of cell entry. J Biol Chem, 2004; 279: 52623-52629.

12. Ravassa $S$, Bennaghmouch $A$, Kenis $H$, Lindhout $T$, Hackeng $T$, Narula J, Hofstra $\mathrm{L}$, Reutelingsperger $\mathrm{C}$. Annexin A5 Down-regulates Surface Expression of Tissue Factor: a novel mechanism of regulating the membrane receptor repertoir. $J$ Biol Chem, 2005; 280: 6028-6035.

13. Narula $\mathrm{J}$, Kietselaer $\mathrm{B}$, Hofstra $\mathrm{L}$, Role of molecular imaging in defining and denying death. J Nucl Cardiol, 2004; 11: 349-357.

14. Maurer-Fogy I, Reutelingsperger CP. Pieters J, Bodo G, Stratowa C, Hauptmann $\mathrm{R}$, Cloning and expression of cDNA for human vascular anticoagulant, a $\mathrm{Ca2}+-$ dependent phospholipid-binding protein. Eur J Biochem, 4988; 174: 585-592.

15. Mira JP, Dubois T, Oudinet JP, Lukowski S, Russo-Marie F, Geny $B$, Inhibition of cytosolic phospholipase $A 2$ by annexin $V$ in differentiated permeabilized HL-60 cells. Evidence of crucial importance of domain I type II Ca2+-binding site in the mechanism of inhibition. J Bial Chem, 1997; 272: 10474-10482.

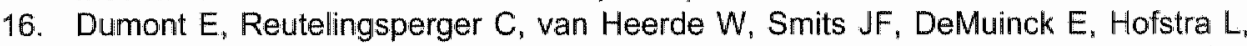
Apoptosis of cardiomyocytes induced by ischemia and reperfusion; early detection with Annexin-V. Lancet, 1999; 353.

17. Bialik S, Geenen DL, Sasson IE, Valnetino KL, Fritz LC, Kitsis RN, The caspase family of cysteine proteases mediate cardiac myocyte apoptosis during myocardial infarction. Circulation; 96: 552-553.

18. Koopman G, Reutelingsperger CP, Kuijten GA, Keehnen RM, Pals ST, van Oers $\mathrm{MH}$. Annexin $\mathrm{V}$ for flow cytometric detection of phosphatidy/serine expression on $\mathrm{B}$ cells undergoing apoptosis. Blood, 1994; 84: 1415-1420.

19. Goldstein JC, Waterhouse NJ, Juin P, Evan GI, Green DR, The coordinate release of cytochrome $c$ during apoptosis is rapid, complete and kinetically invariant. Nat Cell Biol, 2000; 2: 156-162.

20. Martin SJ, Reutelingsperger CP, McGahon AJ, Rader JA, van Schie RC, LaFace DM, Green DR, Early redistribution of plasma membrane phosphatidylserine is a general feature of apoptosis regardless of the initiating stimulus: inhibition by overexpression of Bcl-2 and Abl. JExp Med, 1995; 182: 1545-1556.

21. Savill J, Fadok $V$, Corpse clearance defines the meaning of cell death. Nature, 2000; 407: 784-788.

22. Bratton DL, Fadok VA, Richter DA, Kailey JM, Guthrie LA, Henson PM, Appearance of phosphatidylserine on apoptotic cells requires calcium-mediated nonspecific fllip-flop and is enhanced by loss of the aminophospholipid translocase. J Biol Chem, 1997; 272: 26159-26165.

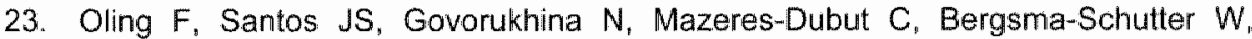
Oostergetel G, Keegstra W, Lambert O, Lewit-Bentley A, Brisson A, Structure of membrane-bound annexin A5 trimers: a hybrid cryo-EM - X-ray crystallography studly. J Mol Bial, 2000; 304: 561-573.

24. Huber $R$, Romisch $J$, Paques EP. The crystal and molecular structure of human annexin $\mathrm{V}$, an anticoagulant protein that binds to calcium and membranes. Embo $J$, $1990 ; 9: 3867-3874$. 
25. Reddien PW, Cameron $S$, Horvitz HR, Phagocytosis promotes programmed cell death in C. elegans. Nature, 2001; 412: 198-202.

26. Hoeppner DJ, Hengariner $M O$, Schnabel $R$, Engulfment genes cooperate with ced3 to promote cell death in Caenorhabditis elegans. Nature, 2001; 412: 202-206.

27. Hammill $A K$, Uhr JW, Scheuermann $R H$, Annexin $V$ staining due to loss of membrane asymmetry can be reversible and precede commitment to apoptotic death. Exp Cell Res, 1999; 251: 16-21.

28. Kaneko $\mathbb{N}$, Matsuda $R$, Hosoda $S$, Kajita $T$, Ohta $Y$, Measurement of plasma annexin $V$ by ELISA in the early detection of acute myocardial infarction. Clin Chim Acta, 1996; 251: 65-80. 


\section{CHAPTER 4}

\section{CELL SURFACE EXPRESSED PHOSPHATIDYLSERINE AND ANNEXIN A5 OPEN A NOVEL PORTAL OF CELL ENTRY}

${ }^{1 \#}$ Heidi Kenis, "Hugo van Genderen, ${ }^{1}$ Abdel Bennaghmouch, ${ }^{2}$ Hilde A. Rinia, ${ }^{1}$ Peter Frederik, ${ }^{3}$ Jagat Narula, ${ }^{1}$ Leo Hofstra and ${ }^{1}$ Chris P.M. Reutelingsperger

1 Cardiovascular Research Institute Maastricht, Maastricht, the Netherlands

2 Leiden Institute of Physics, Leiden, the Netherlands

${ }^{3}$ Department of Medicine-Cardiology, University California Irvine, CA92612, USA.

\# contributed equally to this work

Published in the Journal of Biological Chemistry 2004 Dec 10;279(50):52623-9. 


\section{SUMMARY}

Expression of phosphatidylserine at the cell surface is part of the membrane dynamics of apoptosis. Expressed phosphatidylserine functions as an "eat me" flag towards phagocytes. Here, we report that the expressed phosphatidylserine forms part of a hitherto undescribed pinocytic pathway. Annexin A5, a phosphatidylserine-binding protein, binds to and polymerizes through proteinprotein interactions on membrane patches expressing phosphatidylserine. The two-dimensional protein network of annexin $A 5$ at the surface prevents apoptotic body formation without interfering with the progression of apoptosis as demonstrated by activation of caspase 3, PS exposure and DNA fragmentation. The annexin A5 protein network bends the membrane patch nanomechanically into the cell and elicits budding, endocytic vesicle formation and cytoskeletondependent trafficking of the endocytic vesicle. Annexin A1, which binds to PS without forming a two-dimensional protein network does not induce the formation of endocytic vesicles. This novel pinocytic pathway differs from macropinocytosis, which is preceded by membrane ruffling and actin polymerization. We clearly showed that actin polymerization is not involved in budding and endocytic vesicle formation but is required for intracellular trafficking. The phosphatidylserine-annexin A5-mediated pinocytic pathway is not restricted to cells in apoptosis. We demonstrate that living tumor cells can take up substances through this novel portal of cell entry. This opens new avenues for targeted drug delivery and cell entry. 


\section{INTRODUCTION}

Programmed cell death (PCD) eliminates cells from tissues in a silent and nonprovocative manner. It is essential for development and tissue homeostasis of the multicellular organism. Apoptosis is the most abundant form of $P C D^{1}$. Its well-ordered biochemistry produces the hydrolysis of the cell's vital macromolecular structures ${ }^{2}$ and the appearance of a plethora of "eat me" signals at the cell surface. The latter causes tethering to and engulfment by phagocytes. Phosphatidylserine (PS) is the most well-explored "eat me" signal. It is expressed at the cell surface very early after the onset of execution of apoptosis, regardless of the cell type and the apoptosis-inducing trigger ${ }^{4}$. The binding of expressed PS on the apoptotic cell to the recently described PSreceptor $(P S R)^{5}$ evokes a macropinocytic response in the phagocyte ${ }^{6}$. In addition to its involvement in phagocytosis, surface-expressed PS constitutes a target for imaging of apoptosis using annexin $\mathrm{A} 5$ in vitro ${ }^{7.8}$ and in vivo in animal models $^{9-11}$ and in patients ${ }^{12,13}$.

Annexin A5 is a member of an evolutionary conserved multigene family of $\mathrm{Ca}^{2+}$ and phospholipid-binding proteins ${ }^{14}$. It binds reversibly to PS-expressing membranes with high affinity in a calcium-dependent manner ${ }^{15,}{ }^{16}$ such that ambient extracellular calcium conditions in vivo promote binding to apoptotic cells ${ }^{17}$. Binding to PS is accompanied by the formation of a two-dimensional network of annexin A5 molecules through protein-protein interactions ${ }^{18,19}$. This phenomenon was explored using model membranes but is believed to occur on the apoptotic cell surface also ${ }^{20}$.

Recently we observed internalization of annexin A.5 by apoptotic cells in vivo. Exploration of this phenomenon led to the discovery of the existence of a novel endocytic pathway that can be activated during apoptosis. This study describes the elucidation of the mechanism of this PS-dependent novel portal of cell entry. We furthermore show that this endocytic pathway can also be activated in living tumor cells. This knowledge opens novel avenues for delivery and cell entry of therapeutic compounds.

\section{RESULTS}

\section{ANNEXIN A5 IS INTERNALIZED VIA A PS-DEPENDENT PATHWAY DURING APOPTOSIS.}

Apoptosis is characterized by membrane dynamics, including exposure of PS, membrane blebbing and apoptotic body formation. Surface expression of PS 
can be measured with fluorescently labeled annexin A5 and starts rapidly after the onset of apoptosis ${ }^{4}$.

a

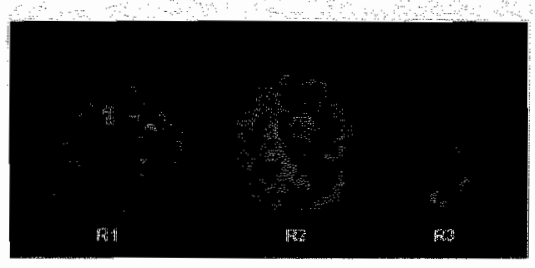

$\mathrm{c}$

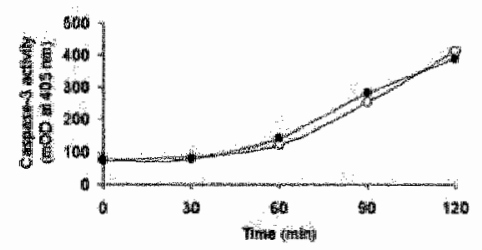

e

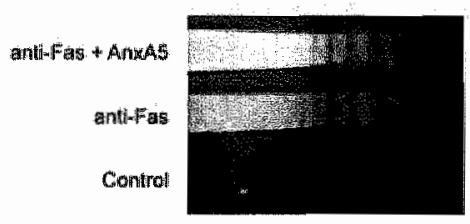

b

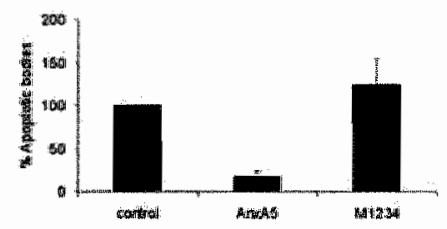

d

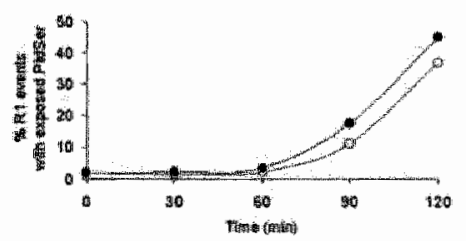

$f$

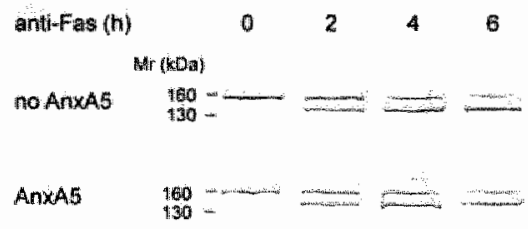

FIG. 1. Annexin A5 inhibits the formation of apoptotic bodies. A, confocal scanning laser microscopy (CSLM) of early apoptotic cells (R1), late apoptotic cells (R2) and apoptotic bodies (R3) stained with annexin A5-Oregon Green and propidium iodide. B, apoptotic body formation of Jurkat cells after treatment with $200 \mathrm{ng} \mathrm{ml}{ }^{-1}$ anti-Fas anti-body for $3 \mathrm{~h}$ in the absence and presence of $10 \mu \mathrm{g} \mathrm{ml}^{-1}$ annexin $\mathrm{A5}$ and $\mathrm{M} 1234 . \mathrm{C}$, time course of caspase-3 activation of anti-Fas treated Jurkat cells in the absence (open circles) and presence (filled circles) of $10 \mu \mathrm{g} \mathrm{m})^{-1}$ annexin A5. D, time-course of PS exposure of antiFas treated Jurkat cells in the absence (open circles) and presence (filled circles) of a mixture of $7.5 \mu \mathrm{g} \mathrm{mi}{ }^{-1}$ annexin A5 and $2.5 \mu \mathrm{g} \mathrm{ml}^{-1}$ annexin A5-FITC to allow determination of PS exposure by flow cytometry. E, DNA laddering after $3 \mathrm{~h}$ of anti-Fas treatment in the absence and presence of $10 \mu \mathrm{g} \mathrm{m}{ }^{-1}$ annexin A5. F. Time course of ROCK-1 cleavage of Jurkat cells treated with anti-Fas antibody in the presence and absence of $10 \mu \mathrm{g} \mathrm{m}^{-1}$ annexin A5. 
Short incubations of anti-Fas-stimulated Jurkat cells with annexin A5-Oregon Green result in plasma membrane staining of early apoptotic cells, massively blebbing apoptotic cells, and apoptotic bodies (Fig. 1A). We observed that coincubation of Jurkat cells with anti-Fas and annexin A5 changed the apoptotic membrane dynamics such that apoptotic body formation was inhibited. This inthibition depends on annexin A5 dose and its ability to bind to PS since its nonbinding mutant M1234 was without effect (Fig. 1B). Co-incubation of Jurkat cells with anti-Fas and annexin A5 did not affect other parts of the apoptotic program such as caspase 3 activation (Fig. 1C), PS expression (Fig. 1D), DNA fragmentation (Fig. 1E) and ROCK-1 activation (Fig. 1F). The latter is involved in membrane blebbing, which precedes apoptotic body formation ${ }^{26}$.

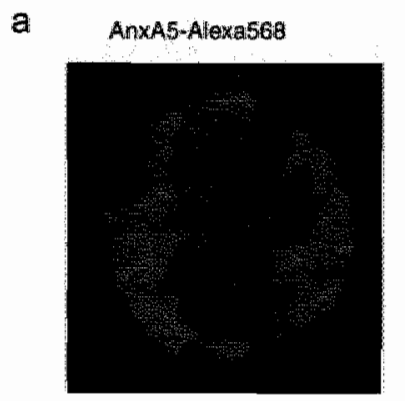

b

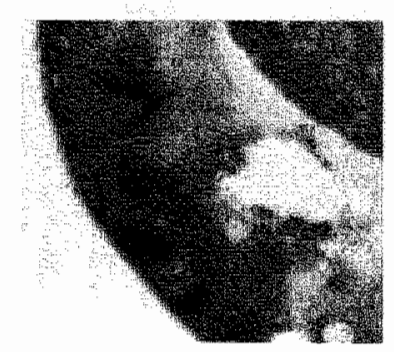

FIG. 2. Annexin A5 is internalized via a PS-dependent pathway during apoptosis. A, CSLM of anti-Fas treated Jurkat cells in the presence of $20 \mu \mathrm{g} \mathrm{m} \mathrm{l}^{-1}$ annexin A5Alexa568. B, immuno-electron microscopy of anti-Fas treated Jurkat cells in the presence of $20 \mu \mathrm{g} \mathrm{ml}^{-1}$ annexin A5. Immunolabeling was performed with anti-annexin A5 antibody and Protein $A$ conjugated with $10 \mathrm{~nm}$ gold.

Inspection of the co-incubated Jurkat cells with confocal scanning laser microscopy (CSLM) and transmission electron microscopy revealled apoptotic cells that had internalized annexin $A 5$ in translucent vesicles of various sizes (Fig. 2A,B). We demonstrated that these vesicular structures are endocytic vesicles and not part of an open cannicular system by i) washing the cells with EDTA and ii) incubating them shortly with annexin A5-Oregon Green prior to CSLM analysis. This procedure neither removed annexin A5-Alexa568 from the vesicular structure nor resulted in co-localization of annexin A5-Alexa568 and annexin A5-Oregon Green. The latter bound to the plasma membrane only. We conclude that annexin A5 is taken up in endocytic vesicles via a PS-dependent mechanism. On the basis of our results so far, we reasoned that annexin A5 
firstly binds to PS-expressing membrane patches prone to become blebs and secondly induces their invagination and budding.

\section{A NOVEL PINOCYTIC PATHWAY INTERNALIZES ANNEXIN A5 INTO CELLS EXECUTING APOPTOSIS.}

The size distribution of the annexin A5 endocytic vesicles suggests that the uptake is a macropinocytic process. This process is preceded by membrane ruffling and dependent on the polymerization of actin ${ }^{27}$. We never observed membrane ruffling when Jurkat cells were co-incubated with anti-Fas and annexin A5. Staining of F-actin with phalloidin-TRITC revealed the presence of an actin coat around the annexin A5-containing vesicles (Fig. 3A,B,C), suggesting the involvement of the actin cytoskeleton. Latrunculin B (Sigma), an inhibitor of actin polymerization, did not prevent the uptake of annexin A5 in endocytic vesicles (Fig. 3D). These vesicles remained localized underneath the plasma membrane indicating that actin polymerization is involved in intracellular trafficking but is not required for invagination and budding. The acto-myosin contractile apparatus is involved in bleb formation during apoptosis via ROCK-1 activation $^{26}$. Y-27632 (Tocris), an inhibitor of ROCK-1, did not inhibit the internalization of annexin A5-Alexa568 (Fig. 3E). Instead, ROCK-1 inhibition led to the formation of large annexin A5-containing vesicles suggesting that the acto-myosin counteracts annexin A5 induced internalization thereby limiting vesicle size. Co-incubation of Jurkat cells having colchicine (Sigma) disrupted microtubules with anti-Fas and annexin A5-Alexa568 resulted in annexin A5containing vesicles that remained attached to the plasma membrane (Fig. 3F), indicating that intracellular trafficking depends on microtubules.

Taken together our data show that annexin A5 is internalized through a process that differs mechanistically from macropinocytosis. 


\section{a}

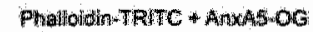

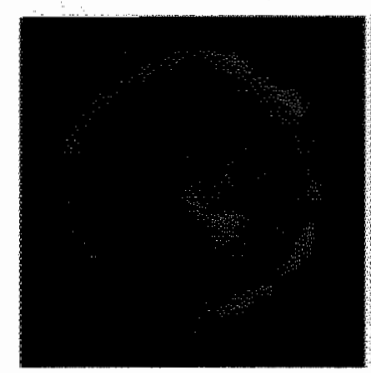

d
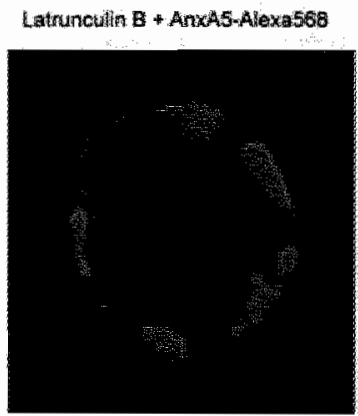

$b$

Hhariodir ThTC And

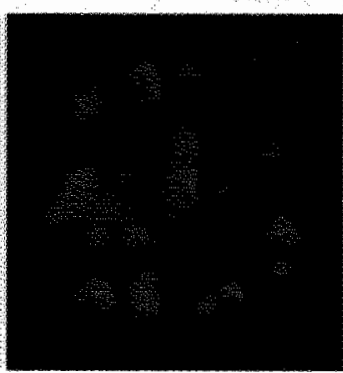

e

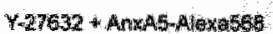

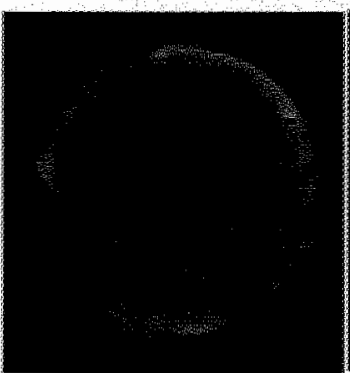

c

Prowhmo

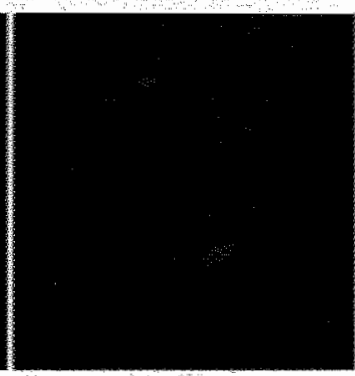

$f$

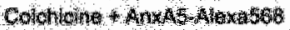

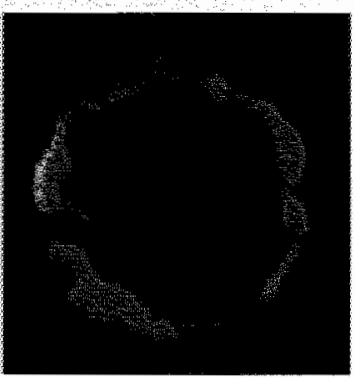

FIG. 3. Effect of cytoskeletal agents on apoptotic body formation and on the internalization of annexin A5. Ax CSLM of anti-Fas treated Jurkat cells in the presence annexin A5-Oregon Green and stained for F-actin with TRITC-labeled Phalloidin. B, C, CSLM of anti-Fas treated Jurkat cells in the presence and absence of cold annexin A5. The cells were fixed and stained for F-actin with TRITC-labeled Phalloidin. D, E, F, CSLM of Jurkat cells treated with $0.5 \mu \mathrm{M}$ latrunculin $\mathrm{B}, 100 \mu \mathrm{M} Y-27632$ and $1 \mu \mathrm{M}$ colchicine $1 \mathrm{~h}$ prior to anti-Fas stimulation in the presence of $20 \mu \mathrm{g} \mathrm{ml}^{-1}$ annexin A5Alexa568 and counterstained with $250 \mathrm{ng} \mathrm{ml}^{-1}$ annexin A5-Oregon Green. 


\section{D-CRYSTALLIZATION OF ANNEXIN A5 IS THE DRIVING FORCE FOR INTERNALIZATION.}

On basis of our results hitherto, we reasoned that annexin A5 reverses membrane fission from blebbing into invagination. Because the annexin A5-PS complex has no transmembrane orientation, direct intracellular signaling by this complex could be ruled out to be the cause for this reversion. Therefore, we started to look for an explanation on a nanomechanical basis. The tertiary structure of annexin A5 shows that its phospholipid binding side has a convex shape ${ }^{28}$. When bound to the membrane annexin A5 forms trimers of which each monomer retains the convex shape at its phospholipid binding side ${ }^{19,29}$. We hypothesized that the trimers bend the membrane and provide the driving force for the reversion of membrane movement. To test the hypothesis we generated the annexin $A 5$ mutant $M 23^{21}$, which by prediction from the available structural data $^{19,28}$, binds to PS but lacks the ability to form trimers. Using a novel FRET assay we show that annexin A5 but not M23 develops FRET when bound to a phospholipid surface (Fig. 4A). Atomic Force Microscopic analysis of phospholipid-bound annexin A5 and M23 revealed the ordered array formation of the former and the disordered organization of the latter (Fig. 4B).

The convex shape of phospholipid-bound annexin A5 trimers was demonstrated to induce invagination of part of the membrane using large unilamellar vesicles. Structures with typically invaginated cups were obtained (see "Experimental Procedures") (Fig. 4C). The thickness of both the cup membrane with a negative curvature (Fig. 4D, nc) and the outer membrane with a positive curvature $(p c)$ were $4.96 \pm 0.75 \mathrm{~nm}$. Incubating these structures with annexin A5 at subsaturating conditions resulted in thicknesses of $9.57 \pm 1.46 \mathrm{~nm}$ and $5.26 \pm 0.76 \mathrm{~nm}$ for negative and positive curvature, respectively. This shows that the annexin A5 network bound to the membrane is bended with a convex shape of its phospholipid binding side. Incubation of the vesicles with M23 yielded thicknesses of $5.91 \pm 0.96 \mathrm{~nm}$ and $5.66 \pm 0.75 \mathrm{~nm}$ for $\mathrm{nc}$ and $\mathrm{pc}$, respectively. All together, it is evident that annexin A5 and not M23 organizes at the phospholipid surface in a bended network. Co-incubation of Jurkat cells with anti-Fas and M23 resulted in the generation of large surface blebs with M23 at the outside and F-actin at the inside (Fig. 4E). No intracellular vesicles containing M23 were observed.

Summarizing these results, we demonstrate that annexin A5 opens a PSdependent novel portal of cell entry by bending the membrane inwards into the cell through 2D-crystallization. 
a

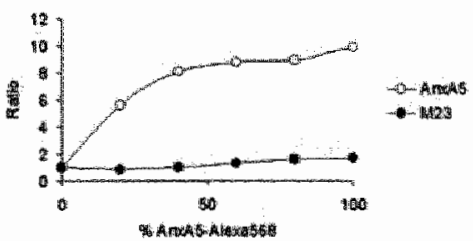

6

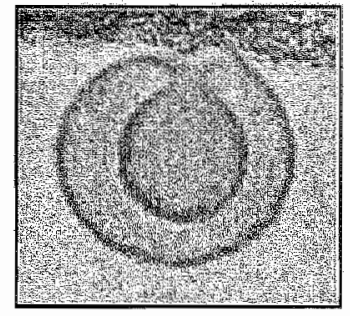

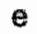

M23-FITC + PhalloidinoTRtTC b.

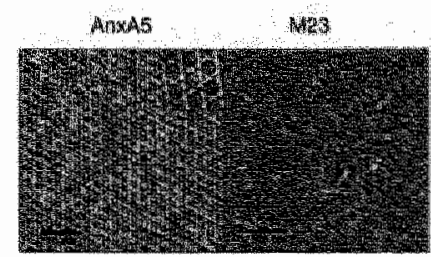

d

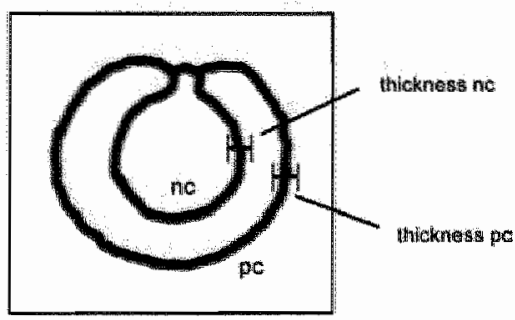

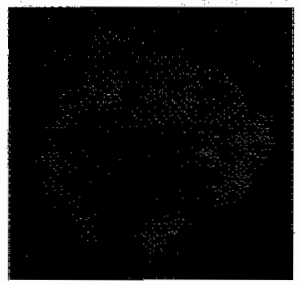

FIG. 4. 2D-crystallization of annexin A5 is the driving force for internalization. $A_{n}$ fluorescence resonance energy transfer (FRET) was measured on the surface of phospholipid-coated beads for the mixtures annexin A5-FITC/annexin A5/annexin A5Alexa568 and M23-FITC/M23/M23-Alexa568. Open circles represent the MFI ratio of annexin A5-Alexa568 in the presence and absence of annexin A5-FITC. Filled dots represent the MFI ratio of M23-Alexa568 in the presence and absence of M23-FITC. B, atomic force microscopy (AFM) images of supported phospholipid bilayers, after incubation with annexin A5 (left panel) or with M23 (right panel). The latter resulted in a disordered layer of protein on the bilayer surface: a crystal lattice as seen in the left panel, or any other type of order was never observed in such layers and higher magnification resulted in hazy images. The inset shows a larger magnification of the crystal lattice (image size inset $70 \mathrm{~nm}$ ). C, cryo-TEM image of a unilamellar vesicle treated with a hyper-osmotic shock. D, schematic representation of the negative (nc) and positive $(\mathrm{pc})$ curvature of a unilamellar vesicle treated with a hyper-osmotic shock. $E_{\text {. }}$ CSLM of anti-Fas treated Jurkat cells in the presence of $20 \mu \mathrm{g} \mathrm{m})^{-1}$ M23-FITC and stained for F-actin with TRITC-labeled Phalloidin. 
LIVING CELLS BEAR A PS-DEPENDENT PORTAL OF ENTRY.

Execution of apoptosis results in the surface expression of PS, which functions as a determinant for the entry of annexin A5. To determine whether apoptosis is an essential element for internalization, we incubated HeLa cells that were not submitted to apoptotic stimuli with annexin A5-Alexa568. After 3 hours of incubation more than $50 \%$ of the HeLa cells had internalized annexin A5 in vesicles of varying sizes, similar to those observed in apoptotic Jurkat cells (Fig. $5 A)$. The internalization was not coupled to the execution of the apoptotic program because i) ZVAD-fmk (IDN 1529, Idun Pharmaceuticals) did not inhibit annexin A5 internalization and ii) the cells with internalized annexin A5 were viable (data not shown). Apart from this discrepancy viable HeLa cells share the modus operandi with Jurkat cells executing apoptosis concerning the entry of annexin A5 into the cell. Annexin A5 internalization is dependent on the PS binding and 2D-crystallization properties of annexin A5, because HeLa cells did not internalize fluorescently labeled M1234 and M23. Furthermore, latrunculin B did not inhibit the internalization of annexin A5. Both latrunculin B and colchicine prevented the intracellular trafficking of the annexin A5 containing vesicles. Further examination of the pathway of uptake demonstrates that it differs from known portals of cell entry ${ }^{27}$. Annexin A5 uptake occurs neither through fluid phase internalization (Fig. 5B) nor through clathrin and caveolin-mediated entry $^{30}$ (Fig. 5C,D). Taken together our data show that both cells executing apoptosis and living tumor cells have the same PS-dependent portals of cell entry. 
a.

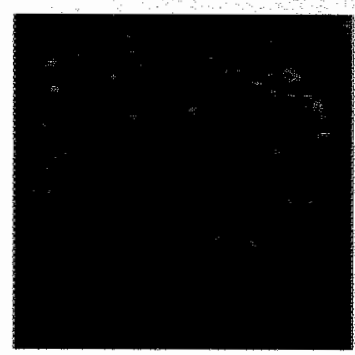

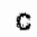

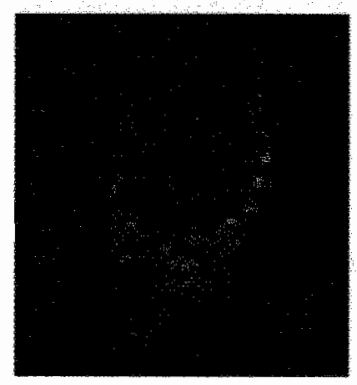

b

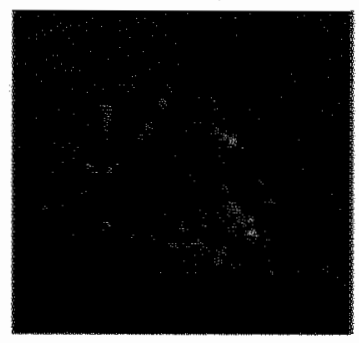

$d$

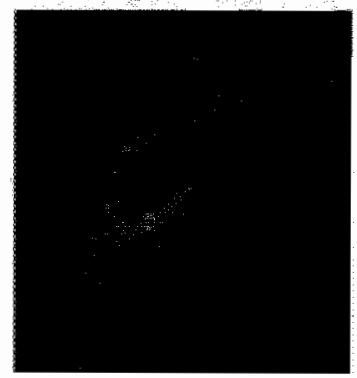

FIG. 5. Annexin A5 is not internalized by HeLa cells via a known endocytic pathway. A, CSLM of living HeLa cells which have internalized annexin A5-Alexa568. B, CSLM of HeLa cells which have internalized annexin A5-Alexa568 and the macropinocytic probe Oregon Green. The two different vesicle populations show that annexin A5-Alexa568 is not internalized via macropinocytosis. C, CSLM of HeLa cells which have internalized annexin A5-Alexa568 and transferrin-Oregon Green488. Vesicles positive for annexin A5-Alexa568 do not co-localize with vesicles positive for transferrin-Oregon Green488 showing that different pathways are activated for each protein. D. HeLa cells were transfected with caveolin 1-EGFP and $24 \mathrm{~h}$ later incubated with annexin A5-Alexa568. Annexin A5-Alexa568 does not co-localize with caveolin 1-EGFP demonstrating that annexin A5-Alexa568 does not enter the cell via caveolin 1-mediated endocytosis. 
THE SPECIFICITY OF THE NOVEL PORTAL OF CELL ENTRY.

In order to investigate further how mandatory the 2D-crystallization is for endocytosis, we used annexin A1. This annexin binds to PS but does not form a 2D-protein network on the membrane surface ${ }^{31}$. Co-incubation of Jurkat cells with anti-Fas and annexin A1-Alexa568 results only in plasma membrane staining of the apoptotic Jurkat cells but not in the formation of endocytic vesicles typically seen with annexin A5 (Fig. 6). Similar results were obtained with living Hela cells. Interestingly, annexin A5 shuttles annexin A1 into the cell demonstrating that this novel pathway leads to internalization of proteins bound to or in the vicinity of surface expressed PS. The latter has been demonstrated for tissue factor, which is internalized in PS-expressing cells by annexin $A 5^{32}$.

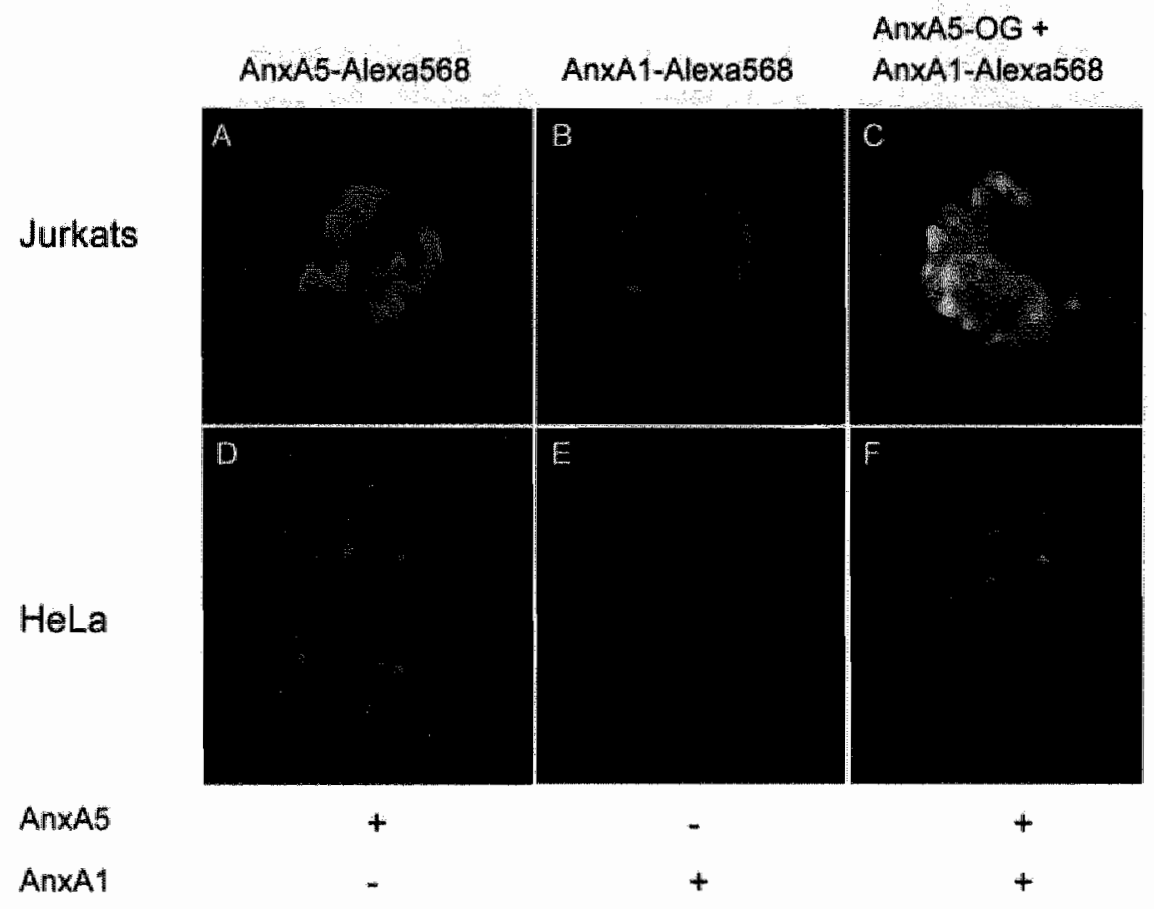

FIG. 6. Annexin A5 and not annexin A1 opens the novel portal of cell entry. Panels A-C present CSLM analyses of Jurkat cells that were co-incubated with anti-Fas and annexin A5-Alexa568 (A), annexin A1-Alexa568 (B) or the combination of annexin A5-Oregon Green and annexin A1-Alexa568 (C). Panels D-F present CSLM analyses of living HeLa cells that were incubated with annexin A5-Alexa568 (D), annexin A1-Alexa568 (E) or the combination of annexin A5-Oregon Green and annexin A1-Alexa568 (F). 


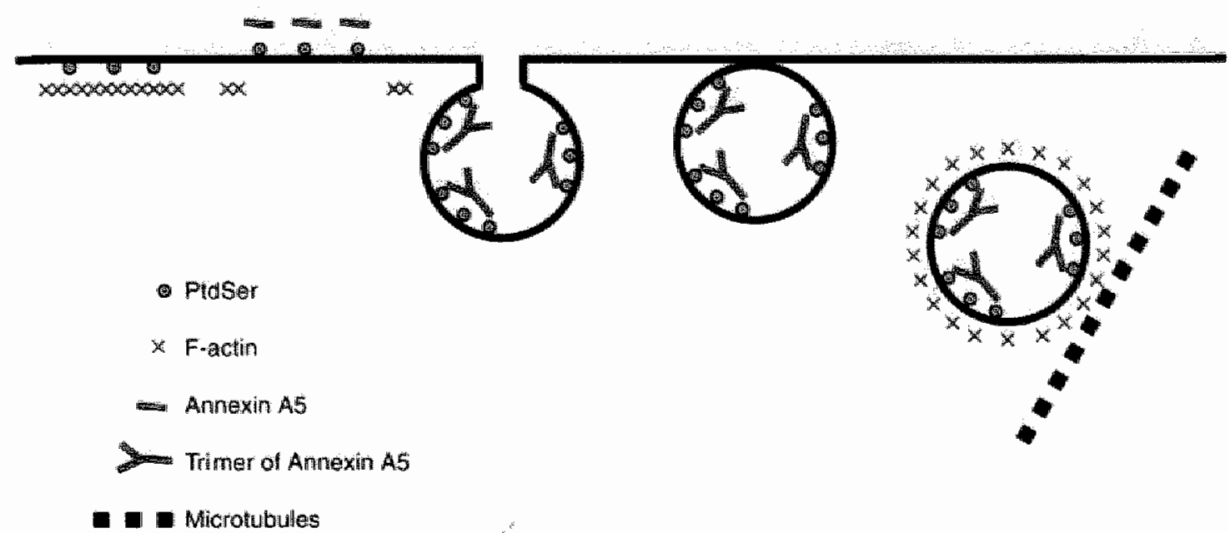

FIG. 7. Model for the pinocytic pathway mediated by surface-expressed PS and annexin A5. Cell surface expression of PS results in disassembly of the cortical actin network underlying the PS-exposing membrane patch. Annexin A5 binds to PS, crystallizes and bends the membrane patch towards invagination. The invaginated membrane cup is closed, encapsulated with F-actin and transported into the cytosol in a microtubuledependent manner.

\section{EXPERIMENTAL PROCEDURES}

\section{CHEMICALS}

Human apo Transferrin was purchased from Sigma and Tris-(hydroxymethyl)aminomethane (Tris) was from Acros Organics.

\section{CELL CULTURE}

The T-lymphoma cell line Jurkat (ATCC) was routinely grown in RPMI 1640 medium (Gibco BRL), containing 100 units $\mathrm{ml}^{-1}$ penicillin, $0.1 \mathrm{mg} \mathrm{ml}^{-1}$ streptomycin (Gibco BRL), and 10\% Fetal Calf Serum (PAA Laboratories $\mathrm{GmbH}$ ). HeLa cells (ATCC), were maintained in Modified Eagle Medium (MEM) with Earl's salts (Gibco BRL) supplemented with 10\% Fetal Calf Serum, 1\% non-essential amino acids, 100 units $\mathrm{ml}^{-1}$ penicillin, $0.1 \mathrm{mg} \mathrm{ml}^{-1}$ streptomycin (Gibco BRL). The cells were grown at $37^{\circ} \mathrm{C}$ in a humidified atmosphere and $5 \%$ $\mathrm{CO}_{2}$. 
CLONING, EXPRESSION, PURIFICATION AND LABELING OF ANNEXIN A5, M23, M1234 AND ANNEXIN A1

CDNA encoding for the annexin A5 mutant M1234 (E72D, D144N, E228A and $\mathrm{D} 303 \mathrm{~N}$ ) having four defective calcium binding sites was kindly provided by Prof. Dr. F. Russo-Marie (BIONEXIS-Pharmaceuticals). The M1234 cDNA was recloned to remove the $5^{\prime}$ basepairs responsible for the 3 extra $N$-terminal amino acids after expression ${ }^{21}$. The annexin A5 mutant M23 was generated by subcloning the mutations $\mathrm{D} 144 \mathrm{~N}$ and E228A into the annexin A5 CDNA. Annexin A5, M23 and M1234 CDNA's were cloned into the bacterial expression vector pET-5a (Novagen). Proteins were expressed in Escherichia coli and purified to homogeneity as assessed by silver stained SDS-PAGE and Western blotting. Annexin A5, M23 and M1234 were labeled with Fluoresceinisothiocyanate and Alexa568-succinimidylester according to the manufacturer's protocol (Molecular Probes). The labeled proteins with 1:1 stoichiometry were purified from the mixtures by MonoQ chromatography with Äcta Explorer (Amersham-Pharmacia). Annexin A1 was kindly provided by Dr. E. Solito (London, UK). Annexin A1 was labeled with Alexa568-succinimidylester according to the manufacturer's protocol (Molecular Probes). The PS-binding capacity of annexin A1-Alexa568 was verified by ellipsometry.

\section{ANALYSIS OF APOPTOTIC BODY FORMATION}

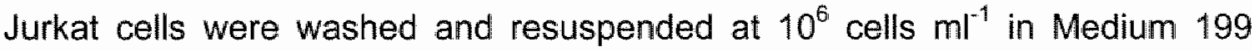
(Gibco BRL) supplied with $0.5 \mathrm{mM} \mathrm{CaCl}_{2}$. Apoptosis was induced with anti-Fas (200 $\mathrm{ng} \mathrm{ml}^{-1}$ ) in the absence or presence of annexin A5 and M1234. The course of apoptosis was determined by flow cytometry using the annexin A5-FITC staining protocol (Nexins). Apoptotic body formation was quantified with flow cytometry and subsequent off-line calculation of the $\%$ of events with reduced forward and sideward scatter. Off-line analysis of the flow cytometer files was performed with WinMDI 2.8 (free share software designed by Joseph Trotter).

\section{CASPASE 3 ACTIVITY, PS EXPOSURE, ROCK-1 CLEAVAGE AND DNA LADDERING}

Caspase 3 activity was determined in $2.5 \times 10^{6}$ Jurkat cells by resuspending the cells in $100 \mu \mathrm{l}$ ice-cold buffer ( $25 \mathrm{mM}$ Hepes/ $\mathrm{NaOH}, 140 \mathrm{mM} \mathrm{NaCl}, 1 \mathrm{mM}$ EDTA $\mathrm{pH} \mathrm{7.4)} \mathrm{after} \mathrm{stimulation} \mathrm{with} \mathrm{anti-Fas.} \mathrm{Cells} \mathrm{were} \mathrm{disrupted} \mathrm{by} \mathrm{ultrasonication}$ and cellular debris was removed by centrifugation $\left(140,000 \times\right.$ gmin, $\left.4^{\circ} \mathrm{C}\right), 5 \mu \mathrm{l}$ of chromogenic substrate (10 mM DEVD-pNa (BioSource)) was added to $70 \mu \mathrm{l}$ of the cellular supernatant. The mixture was incubated at $37^{\circ} \mathrm{C}$ for $30 \mathrm{~min}$ and optical density (OD) was measured at $405 \mathrm{~nm}$. 
PS exposure of anti-Fas stimulated Jurkat cells was measured by flow cytometry using annexin A5-FITC. If apoptosis was executed in the presence of annexin A5, a mixture of $7.5 \mu \mathrm{g} \mathrm{m} \mathrm{m}^{-1}$ annexin $\mathrm{A} 5$ and $2.5 \mathrm{\mu g} \mathrm{m}^{\mathrm{t}}$ annexin $\mathrm{A} 5$ FITC was added to the cells prior to the addition of anti-Fas.

ROCK-1 activation was determined by lysing Jurkat cells in Tris buffer containing $50 \mathrm{mM}$ Tris, $50 \mathrm{mM}$ EDTA, $0.1 \%$ Triton- $\mathrm{X}-100$ and $0.5 \%$ protease inhibitor cocktan (Sigma). Lysates of $10^{6}$ cells were loaded per well and submitted to SDS-PAGE and Western blotting using anti-ROCK-1 antibody (SantaCruz).

DNA fragmentation was analyzed by resuspending $5 \times 10^{6}$ cells in $600 \mu$ icecold lysis buffer $(10 \mathrm{mM}$ Tris/10 mM EDTA/0.5\% Triton-X-100, pH 8.0). The mixture was incubated $10 \mathrm{~min}$ on ice. The lysates were cleared by centrifugation $\left(40,000 \times \mathrm{gmin}, 4^{\circ} \mathrm{C}\right)$. DNA was extracted from the supernatant with an equal volume phenol/chloroform/isoamyl alcohol (16:16:1). The water phase was adjusted to $300 \mathrm{mM} \mathrm{NaCl}$ and diluted with 2.5 volumes ice-cold $100 \%$ ethanol. Following overnight precipitation at $4^{\circ} \mathrm{C}$, the DNA was pelleted and washed once with ice-cold $70 \%$ ethanol. The DNA was dried in a speed VAC and resuspended in $10 \mu$ Tris-EDTA containing RNaseA. The DNA fragments were separated on a $1.2 \%$ agarose gel.

\section{CONFOCAL SCANNING LASER MICROSCOPY (CSLM)}

Jurkat cells $\left(2 \times 10^{6}\right.$ cells ml-1) were stimulated with anti-Fas $\left(200 \mathrm{ng} \mathrm{m}^{-1}\right)$ in the presence of annexin A5-Alexa568 (20 $\left.\mu \mathrm{g} \mathrm{m}^{-1}\right)$, annexin A1-Alexa568 (20 $\mathrm{Hg}$ $\left.\mathrm{m}^{-1}\right)$ and cytoskeletal agents if indicated. After $3 \mathrm{~h}$ the cells were pelleted $(2 \mathrm{mth}$ $1,000 \mathrm{~g}$ ), washed with EDTA-buffer (140 mM NaCl/25 mM Hepes/5 mM EDTA, $\mathrm{pH} \mathrm{7.4)}$ and resuspended in $\mathrm{Ca}^{2+}$-buffer $(10 \mathrm{mM}$ Hepes, $150 \mathrm{mM} \mathrm{NaCl}, 5 \mathrm{mM}$

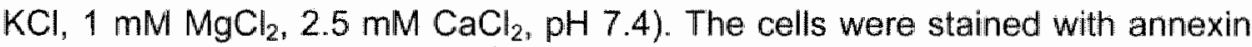

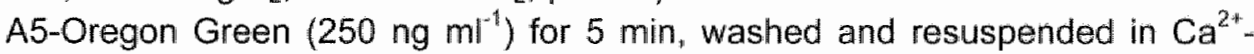
buffer containing $4 \%$ paraformaldehyde. After a fixation period of $10 \mathrm{~min}$, the cells were stained with phalloidin-TRITC according to the manufacturer's protocol (Molecular probes).

HeLa cells were seeded on glass cover slips and left to adhere in culture medium. After $24 \mathrm{~h}$, one or a combination of the fluorescently labeled proteins was added in a concentration of $100 \mathrm{nM}$. HeLa cells were incubated at $37^{\circ} \mathrm{C}$ and $5 \% \mathrm{CO}_{2}$ for $3 \mathrm{~h}$. The HeLa cells were washed sequentially with phosphate buffered saline (PBS), EDTA-buffer and PBS. The cells were then fixed for 15 min in $\mathrm{Ca}^{2+}$-buffer containing $4 \%$ paraformaldehyde $(\mathrm{pH} 8.0)$ and washed three times for $20 \mathrm{~min}$ in PBS. 
The fixed Jurkat or HeLa cells were mounted in $90 \%$ glycerol in $0.02 \mathrm{M} \mathrm{Tris-HCl}$ pH 8.0 with addition of $2 \%$ 1,4-diazobicyclo-[2,2,2]-octane (Merck). Slides were examined with a confocal scanning laser microscope (Bio-Rad) equipped with a Crypton/Argon mixed gas laser (lon Laser Technology). Images were recorded and analyzed with NIH image, Image J and Adobe Photoshop. Variations on this standard protocol were used to study the internalization of annexin A5-Alexa568 (100 nM), M1234-Alexa568 (100 nM), annexin A1-Alexa568 (100 nM), M23Alexa568 (100 nM), transferrin-Oregon Green $488(100 \mathrm{nM})$ and Oregon Green labeled Tris $(20 \mu \mathrm{M})$ with the succinimidylester group inactivated.

\section{PLASMID AND TRANSFECTION}

The plasmid caveolin-1-GFP was a kind gift of Dr. D. Mundy (University of Texas, Southwestern Medical Center, Dallas). The plasmid was transfected in HeLa cells with the transfection agent Fugene 6 (Roche).

\section{IMMUNO-ELECTRON MICROSCOPY (IEM)}

$2 \times 10^{6}$ Jurkat cells were stimulated with $200 \mathrm{ng} \mathrm{m}^{-1}$ anti-Fas in the presence of $20 \mu \mathrm{g} \mathrm{m} \mathrm{l}^{-1}$ annexin A5. The cells were pelleted by centrifugation (15,000 $\times$ gmin) and resuspended in $\mathrm{Ca}^{2+}$-buffer containing $2 \%$ paraformaldehyde, $0.2 \%$ glutaraldehyde. After $10 \mathrm{~min}$ the cells were transferred to $\mathrm{Ca}^{2+}$-buffer containing $1 \%$ paraformaldehyde. The fixed cells were washed with PBS, resuspended in $20 \mu$ PBS containing $10 \%$ gelatine, and solidified by cooling down. The gelatine drops were stored overnight at $4^{\circ} \mathrm{C}$ in PBS containing $2.3 \mathrm{M}$ sucrose and then vitrified in liquid nitrogen for subsequent cryosectioning $( \pm 90 \mathrm{~nm}$ ) on a Leica EM FCS Cryo-Microtoom. The ultrathin sections were stained with anti-annexin A5 antibody (Hyphen Biomed) and Protein A conjugated with $10 \mathrm{~nm}$ gold (a kind gift of Dr. G. Postuma, University Medical Center Utrecht, Dept. Cell Biology, G.Posthuma@lab.AZU.NL), washed with PBS containing $0.1 \%$ w/v BSA, postfixed in $1 \%$ glutaraldehyde, rinsed in ice cold $1.8 \%$ Methylcellulose $10.4 \%$ Uranylacetate and stained in ice cold $1.8 \%$ Methylcellulose/ $0.4 \%$ Uranylacetate for $5-10 \mathrm{~min}$. The grids were air dried and examined in a Philips CM 10 microscope at $80 \mathrm{keV}$.

\section{TRANSMISSION CRYO-ELECTRON MICROSCOPY (TCEM)}

Extruded phospholipid vesicles of dioleoyl phosphatidylcholine (DOPC), dioleoyl phosphatidylserine (DOPS) and cholesterol (molar ratio $63.3: 3.3: 33.3$ ) were prepared by passing a mixture of $10 \mathrm{mM}$ hand shaken liposomes of above composition at least three times through a $100 \mathrm{~nm}$ filter (Anotop 10, Whatman). 
The extruded vesicles were submitted to a mild hypotonic shock to obtain 100 $\mathrm{nm}$ diameter vesicles with a perfect spherical shape.

Annexin A5 or M23 was added to the vesicles at a weight ratio of $1: 4$ in the absence of $\mathrm{Ca}^{2+}$-ions. At this ratio maximally $50 \%$ of the phospholipid surface can be covered with annexin A5 upon binding ${ }^{15}$. Annexin A5 binding to the vesicles was achieved by adding $\mathrm{Ca}^{2+}$-ions to the mixture such that the final $\mathrm{Ca}^{2+}$-ion concentration was $2.5 \mathrm{mM}$ and the solution became hypertonic relative to the lumen of the vesicles. The vesicles were prepared for cryo-EM analysis on a Philips $\mathrm{CM} 12$ microscope (Philips) using the Vitrobot ${ }^{\mathrm{TM}} 22$.

\section{FLUORESCENCE RESONANCE ENERGY TRANSFER (FRET)}

FRET was determined with FITC and alexa568-labeled proteins as donors and acceptors respectively. Mixtures of annexin A5-FITC/annexin A5/annexin A5Alexa568 or M23-FITC/ M23/M23-Alexa568 were prepared in ratios $100 / 100 / 0$, $100 / 80 / 20,100 / 60 / 40,100 / 40 / 60,100 / 20 / 80$ and 100/0/100. Mixtures of annexin A5/annexin A5-Alexa568 or M23/M23-Alexa568 were prepared in ratios 200/0, $180 / 20,160 / 40,140 / 60,120 / 80$ and $100 / 100$. These mixtures were incubated with M-PVA-12 beads (Chemagen), which were coated with a phospholipid layer consisting of $35 \%$ dioleoyl phosphatidylcholine, $20 \%$ dioleoyl phosphatidylethanolamine, $10 \%$ dioleoyl phosphatidylserine and $35 \%$ cholesterol in $\mathrm{Ca}^{2+}$-buffer ${ }^{23}$. The fluorescence bound to the beads was measured on a Coulter Epics XL-MLC ${ }^{T M}$ flow cytometer. The mean fluorescence intensity (MFI, arbitrary units) was calculated off-line for the Alexa568 signal in channel 3 (MFI-FL3). FRET was calculated as follows: MFIFL3 of the mixtures containing FITC divided by MFI-FL3 of the mixtures without FITC.

\section{ATOMIC FORCE MICROSCOPY (AFM)}

AFM studies were performed following an adaptation of a described procedure ${ }^{24}$. Supported lipid bilayers of Egg-PC, DOPS and cholesterol $(46: 20: 34)$ were made on mica with the vesicle fusion method ${ }^{25}$. The presence of a bilayer could be verified by the detection of pinholes in the bilayer. The bilayers were incubated for up to $3 \mathrm{~h}$ with the wild type annexin A5 or the M23 (final protein concentrations $15 \mu \mathrm{g} \mathrm{ml^{-1 }}$ ). Samples were imaged with a Nanoscope III using NP probes (both Digital Instruments) with an estimated spring constant of $0.06 \mathrm{~N} \mathrm{~m}^{-1}$. Imaging was done in Contact Mode in fluid exerting low force $(\sim 100 \mathrm{pN})$. All samples were made and imaged in Hepes buffer $(10 \mathrm{mM}, 150 \mathrm{mM} \mathrm{NaCl}, 2 \mathrm{mM} \mathrm{CaCl}$, $\mathrm{pH} 7.4)$. Images were low-pass filtered and/or flattened using the Nanoscope software. 


\section{DISCUSSION}

Plasma membrane dynamics during apoptosis include the expression of PS at the cell surface and membrane blebbing. Both phenomena occur during apoptosis downstrearn of caspase 3 activation ${ }^{4}$ but are regulated independently. PS expression occurs under conditions wherein membrane blebbing is inhibited $^{25}$. With fluorescently labeled annexin A5 it was shown that membrane blebs have surface-expressed PS, indicating that the PS-expressing membrane patches are flexible and bendable. Recently, it was reported that annexin A5 inhibits apoptotic body formation by applying a physical constraint on the plasma membrane and inhibiting the apoptotic program ${ }^{20}$. We confirmed that annexin A5 inhibits apoptotic body formation, but it does so in our system without interfering with the key steps of the apoptotic program such as caspase 3 activation, PS expression, ROCK-1 cleavage and DNA fragmentation. Because apoptotic body formation is downstream of membrane blebbing ${ }^{26}$, the inhibitory mechanism may operate on membrane blebs. Our investigations into this phenomenon revealed the existence of an endocytic pathway that is activated by annexin $A 5$ and surface-expressed PS. We demonstrate that annexin A5 reverses the movement of the PS-expressing membrane patch from blebbing into invagination. This results in vesicle formation and intracellular trafficking of the endocytic vesicle (Fig. 7). From the experiments with M23 and annexin $\mathrm{A} 1$ we conclude that the process of invagination is driven nanomechanically by the formation of an annexin A5 two-dimensional crystal that bends the membrane likely due to the bended shape of the trimer building blocks ${ }^{19}$. The mechanism of membrane bending differs from that operating in clathrin-coated pits. Here, insertion of proteins into the lipid layer pushes lipid head groups of one leaflet apart thereby inducing curvature of the bilayer ${ }^{33}$. If annexin A5 would operate comparably it is expected that annexin A5 facilitates blebbing instead of inducing invagination. Therefore, it is concluded that annexin $\mathrm{A} 5$ binds extrinsically and molds the membrane patch according to the convex shape of its phospholipid binding side. The energy required for this action is likely released by the $2 \mathrm{D}$-crystallization process.

The size distribution of the annexin A5 containing endocytic vesicles suggest macropinocytosis rather than clathrin- or caveolin-mediated endocytosis and clathrin- and caveolin-independent endocytosis ${ }^{27}$. In spite of morphological resemblance the two endocytic pathways are mechanistically distinct. Annexin A5 induced endocytosis is neither actin-driven nor preceded by membrane ruffling. Hence, we conclude that the PS-expressing membrane patch forms a novel portal of cell entry, which is opened by annexin A5. 
The relevance of the annexin A5 endocytic pathway during apoptosis is debatable. Why should a cell determined to die be capable of activating endocytic pathways? Inspection of the time course revealed that the endocytic pathway can be activated early after onset of apoptosis, likely as soon as the first PS molecules appear at the surface. Because cell surface expression of PS has been reported for viable cells ${ }^{34 \cdot 37,1}$, the annexin A5 endocytic pathway in apoptotic cells could be a remnant of the pinocytic capabilities of the living cell. In this paper we demonstrate the likelihood of this possibility by showing that the annexin A5 endocytic pathway exists in viable HeLa cells. The pathway in HeLa cells is dependent on PS expression and annexin A5 crystallization and independent of membrane ruffling and actin-polymerization. Furthermore, the pathway is distinct from clathrin- and caveolae-dependent endocytosis and macropinocytosis. In addition, we have strong indications that the pathway also exists in vivo in cardiomyocytes that express PS reversibly on their surface due to a mild ischemia/reperfusion stress ${ }^{2}$. The relevance of the annexin A5 endocytic pathway in living cells remains to be established. Its activation leads to the downregulation of surface-expressed proteins, such as tissue factor ${ }^{32}$. It may therefore play a role in the regulation of proceses such as blood coagulation $^{32}$ and phagocytosis ${ }^{2}$. The annexin A5 endocytic pathway is apparently not operative ubiquitously in healthy non-disturbed tissues ${ }^{17}$. The reported cases of reversible PS expression point towards situations of mild stress such as hypoxia in tumors and the transient ischemic heart that cause reversible PS expression.

While its physiological relevance needs to be investigated, the annexin A5 endocytic pathway already offers an attractive mechanism for targeted delivery and cell entry of drugs designed to kill (tumor cells) or to rescue (ischemic/reperfused cardiomyocytes).

\section{ACKNOWLEDGMENTS}

Parts of this study were made possible by the Dutch Organization for Scientific Research (NWO) grants 902-26-184, 014-80-103 and 912-03-013. Correspondence and requests for materials should be addressed to C.P.M.R.

${ }^{1}$ H. Kenis, J. Narula, L. Hofstra, C.P.M. Reutelingsperger, unpublished observations.

${ }^{2} \mathrm{H}$. Kenis and $\mathrm{C}$. Reutelingsperger, unpublished observations 


\section{REFERENCES}

1. Leist $M$, Jaattela $M$, Four deaths and a funeral: from caspases to alternative mechanisms. Nat Rev Mol Cell Biol, 2001; 2: 589-598.

2. Hengartner MO, The biochemistry of apoptosis. Nature, 2000; 407: 770-776.

3. Savill J, Fadok $V$, Corpse clearance defines the meaning of cell death. Nature, 2000; 407: 784-788.

4. Martin SJ, Reutelingsperger CP. McGahon AJ, Rader JA, van Schie RC, LaFace $D M$, Green DR. Early redistribution of plasma membrane phosphatidylserine is a general feature of apoptosis regardless of the initiating stimulus: inhibition by overexpression of $\mathrm{Bcl}-2$ and Abl. J Exp Med, 1995; 182: 1545-1556.

5. Fadok VA, Bratton DL, Rose DM, Pearson A, Ezekewitz RA, Henson PM, A receptor for phosphatidylserine-specific clearance of apoptotic cells. Nature, 2000; 405: 85-90.

6. Hoffmann $P R$, deCathelineau $A M, O g d e n C A$, Leverrier $Y$, Bratton $D L$, Daleke $D L$, Ridley AJ, Fadlok VA, Henson PM, Phosphatidylserine (PS) induces PS receptormediated macropinocytosis and promotes clearance of apoptotic cells. 1 Cell Biol, 2001; 155: 649-659.

7. van Engeland M, Ramaekers FC, Schutte B, Reutelingsperger $C P$, A novel assay to measure loss of plasma membrane asymmetry during apoptosis of adherent cells in culture. Cytometry, 1996; 24: 131-139.

8. van den Eijnde $\mathrm{SM}$, Boshart $\mathrm{L}$, Baehrecke $\mathrm{EH}$, De Zeeuw $\mathrm{Cl}$, Reutelingsperger $\mathrm{CP}$, Vermeij-Keers $C$, Cell surface exposure of phosphatidylserine during apoptosis is phylogenetically conserved. Apoptosis, 1998; 3: 9-16.

9. Blankenberg FG, Katsikis PD, Tait JF, Davis RE, Naumovski L, Ohtsulki K, Kopiwoda S, Abrams MJ Strauss HW, Imaging of apoptosis (programmed cell death) with 99mTc annexin V. J Nucl Med, 1999; 40: 184-191.

10. Dumont EA, Reutelingsperger $C P$. Smits JF, Daemen MJ. Doevendans PA, Wellens $H J$, Hofstra $L$, Real-time imaging of apoptotic cell-membrane changes at the single-cell level in the beating murine heart. Nat Med, 2001; 7: 1352-1355.

11. van den Eijnde $S M$, Boshart $L$, Reutelingsperger $C P M$, De Zeeuw $C l$, VermeijKeers $\mathrm{C}$. Phosphatidylserine plasma membrane asymmetry in vivo: a pancellular phenomenon which alters during apoptosis. Cell Death Differ, 1997; 4: 311-316.

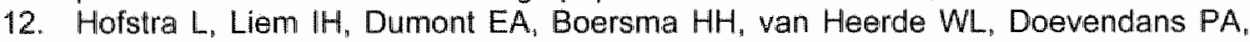
De Muinck $E$, Wellens $H J$, Kemerink GJ, Reutelingsperger CP. Heidendal GA, Visualisation of cell death in vivo in patients with acute myocardial infarction. Lancet, 2000; 356: 209-212.

13. Narula J, Acio ER, Narula N, Samuels LE, Fyfe B, Wood D, Fitzpatrick JM, Raghunath PN, Tomaszewski JE, Kelly C, Steinmetz N, Green A, Tait JF, Leppo J, Blankenberg $F G$, Jain $D$, Strauss $H W$, Annexin- $V$ imaging for noninvasive detection of cardiac allograft rejection. Nat Med, 2001; 7: 1347-1352.

14. Gerke V. Moss SE, Annexins: from structure to function. Physiol Rev, 2002; 82: $331-371$.

15. Andree HA, Reutelingsperger CP, Hauptmann R, Hemker HC, Hermens WT, Willems GM. Binding of vascular anticoagulant alpha (VAC alpha) to planar phospholipid bilayers. J Biol Chem, 1990; 265: 4923-4928. 
16. Tait $J F$, Gibson D, Fujkawa $K$, Phospholipid binding properties of human placental anticoagulant protein-1, a member of the lipocortin family. J Biol Chem, 1989; 264: 7944-7949.

17. van den Eijnde SM, Luijsterburg $A J$, Boshart L, De Zeeuw $C l$, van Dierendonck JH, Reutelingsperger CP. Vermeij-Keers $\mathrm{C}$, In situ detection of apoptosis during embryogenesis with annexin $\mathrm{V}$ : from whole mount to ultrastructure. Cytometry, 1997; 29: 313-320.

18. Mosser $G$, Ravanat $C$, Freyssinet JM, Brisson $A$, Sub-domain structure of lipidbound annexin- $V$ resolved by electron image analysis. I Mol Biol, $1991 ; 217: 241$ 245.

19. Oling $F$, Santos JS, Govorukhina N, Mazeres-Dubut $C$, Bergsma-Schutter $W$, Oostergetel $G$, Keegstra W, Lambert $O$, Lewit-Bentley A, Brisson A, Structure of membrane-bound annexin A5 trimers: a hybrid cryo-EM - X-ray crystallography study. I Mol Biol, 2000; 304: 561-573.

20. Gidon-Jeangirard $C$, Hugel $B$, Holl V, Toti $F$, Laplanche $J L$, Meyer D, Freyssinet $J M$, Annexin $V$ delays apoptosis while exerting an external constraint preventing the release of $\mathrm{CD} 4+$ and $\mathrm{PrPC}+$ membrane particles in a human $\mathrm{T}$ lymphocyte model. J Immunol, 1999; 162: $5712-5718$.

21. Mira JP, Dubois T, Oudinet JP, Lukowski S, Russo-Marie F, Geny B, Inhibition of cytosolic phospholipase A2 by annexin $V$ in differentiated permeabilized HL-60 cells. Evidence of crucial importance of domain I type II Ca2+-binding site in the mechanism of inhibition. I Biol Chem, 1997; 272: 10474-10482.

22. Frederik PM, Hubert DH, Cryoelectron Microscopy of Liposomes. Methods Enzymol, 2005; 391: 431-448.

23. Boersma HH, Stolk $L M$, Kenis $H$, Deckers $N M$, Vanderheyden Jl, Hofstra $L$, Heidendal GA, Reutelingsperger CP. The ApoCorrect assay: a novel, rapid method to determine the biological functionality of radiolabeled and fluorescent Annexin A5. Anal Biochem, 2004; 327: 126-134.

24. Reviakine II, Bergsma-Schutter W, Brisson A, Growth of Protein 2-D Crystals on Supported Planar Lipid Bilayers Imaged in Situ by AFM. J Struct Biol, 1998; 121: 356-361.

25. Rinia HA, Snel MM, van der Eerden JP, de Kruijff $B$, Visualizing detergent resistant domains in model membranes with atomic force microscopy. FEBS Lett, 2001"501: 92-96.

26. Coleman ML, Sahai EA, Yeo M, Bosch M, Dewar A, Olson MF, Membrane blebbing during apoptosis results from caspase-mediated activation of ROCKI. Nat Cell Biol. $2001 ; 3: 339-345$.

27. Conner SD, Schmid SL, Regulated portals of entry into the cell. Nature, 2003; 422: $37-44$.

28. Huber $R_{1}$ Romisch J, Paques EP. The crystal and molecular structure of human annexin $V$, an anticoagulant protein that binds to calcium and membranes. Embo $J$, 1990; 9: 3867-3874.

29. Huber R, Schneider M, Mayr I, Romisch J, Paques EP, The calcium binding sites in human annexin $V$ by crystal structure analysis at $2.0 \mathrm{~A}$ resolution. Implications for membrane binding and calcium channel activity. FEBS Lett, 1990; 275: 15-21.

30. Mundy DI, Machleidt T, Ying YS, Anderson RG, Bloom GS, Dual control of caveolar membrane traffic by microtubules and the actin cyloskeleton. J Cell SCl, 2002; 115: $4327-4339$. 
31. Govorukhina $\mathbb{N}_{\text {s }}$ Bergsma-Schutter $\mathbf{W}$, Mazères-Dubut $C$, Mazères $S_{\text {, Drakopoulou }}$ $E_{\text {; }}$ Bystrykh L, Oling F, Mukhopadhyay A, Reviakine I, J. LKH, A. B, Self-assembly of annexin A5 on lipid membranes., in Annexins: Biological importance and annexin-related pathologies. J. Bandorowicz-Pikula, Editor. 2002, Landes Bioscience: Georgetown USA. p. 40-58.

32. Ravassa $S$, Bennaghmouch $A$, Kenis $H$, Lindhout $T$, Hackeng $T$, Narula J, Hofstra $\mathrm{L}$, Reutelingsperger $\mathrm{C}$, Annexin A5 Down-regulates Surface Expression of Tissue Factor: a novel mechanism of regulating the membrane receptor repertoir. J Biol Chem, 2005; 280: 6028-6035.

33. Ford MG, Mills $1 G$, Peter BJ, Vallis $Y$, Praefcke GJ, Evans PR, McMahon HT, Curvature of clathrin-coated pits driven by epsin. Nature, 2002; 419: 361-366.

34. Hammill AK, Uhr JW, Scheuermann RH, Annexin $V$ staining due to loss of membrane asymmetry can be reversible and precede commitment to apoptotic death. Exp Cell Res, 1999; 251: 16-21.

35. van den Eijnde $S M$, van den Hoff $M J$, Reutelingsperger $C P$, van Heerde $W L$, Henfling ME, Vermeij-Keers C, Schutte B, Borgers M, Ramaekers FC, Transient expression of phosphatidylserine at cell-cell contact areas is required for myotube formation. J Cell Sci, 2001; 114: 3631-3642.

36. Kuijpers TW, Maianski NA, Tool AT, Becker $K$, Plecko $B$, Valianpour $F$, Wanders RJ, Pereira R, Van Hove J, Verhoeven Ad, Roos D, Baas F, Barth PG, Neutrophils in Barth Syndrome (BTHS) avidly bind Annexin- $V$ in the absence of apoptosis. Blood, 2004.

37. Ran $S$, Thorpe $P E$, Phosphatidylserine is a marker of turnor vasculature and a potential target for cancer imaging and therapy. Int J Radiat Oncol Biol Phys, 2002; 54: $1479-1484$. 


\section{CHAPTER 5}

\section{ANNEXIN A5 INHIBITS ENGULFMENT THROUGH INTERNALIZATION OF PS-EXPRESSING CELL MEMBRANE PATCHES}

${ }^{1}$ Heidi Kenis, 'Hugo van Genderen, 'Niko M. Deckers, ${ }^{1}$ Petra A.G. Lux, ${ }^{2}$ Leo Hofstra, ${ }^{3}$ Jagat Narula and ${ }^{4}$ Chris P.M. Reutelingsperger

1 Dept. of Biochemistry, Cardiovascular Research Institute Maastricht, Maastricht, the Netherlands

2 Dept. of Cardiology, Cardiovascular Research Institute Maastricht, Maastricht, the Netherlands

${ }^{3}$ Dept. of Cardiology, University of California Irvine, Irvine, USA

Submitted for publication to Experimental Cell Research 


\section{ABSTRACT}

Apoptosis and subsequent clearance of apoptotic cells is important for the prevention of diseases. Therefore, it is essential to understand the mechanisms underlying the biology of phagocytic clearance of apoptotic cells. The best characterized "eat me" signal on the surface of apoptotic cells is phosphatidylserine (PS). Recently, we demonstrated that annexin A5 mediates the internalization of PS-expressing membrane patches and downregulates surface expression of tissue factor. Here, we investigated the role of PS in the phagocytosis of apoptotic cells using annexin A5. Using a novel flow cytometricbased phagocytosis assay, we observed that engulfment was inhibited with $20 \%$ if annexin A5 was added to PS-expressing cells that had completed apoptosis. The inhibition increased to more than $50 \%$ if annexin A5 was added during the apoptotic process. This inhibition is specific for annexin A5, since the mutant M23 and annexin A1 did not further increase the inhibition of phagocytosis when added during the apoptotic process. Interestingly, cells with internalized annexin A5 still express PS at their surface. We conclude that other ligands than PS function as "eat me" signals within the PS-expressing membrane patch. 


\section{INTRODUCTION}

Apoptosis is the most abundant form of programmed cell death in metazoan biology. It constitutes an essential part of development and homeostasis. Apoptosis is responsible for the removal of superfluous, damaged or harmful cells from the tissues. It is estimated that in the human body $10^{10}$ cells die every day. This creates the danger of autoimmune and inflammatory reactions at sites where cells die and spill their cellular content into the surrounding tissue. This danger is dampened by phagocytes, which remove dying cells through engulfment well before they start to disintegrate. In addition, whille engulfing apoptotic cells phagocytes suppress inflammation by secreting antiinflammatory cytokines ${ }^{2-4}$. In vivo, apoptotic cells are essentially always found inside phagocytes in healthy tissues ${ }^{5}$. Engulfment can therefore be considered as a process that is essential for the prevention of diseases.

Engulfment of apoptotic cells is an intricate process involving "find me" and "eat me" signals from the apoptotic cell and a broad set of receptors at the surface of the phagocyte ${ }^{6,7}$. Phosphatidylserine (PS) is the most well explored "eat me" signal of the apoptotic cell. PS is thought to cooperate with other "eat me" signals in a manner best described by tethering and tickling ${ }^{8,9}$. PS-mediated tickling evokes engulfment of the tethered apoptotic cell and activation of signaling pathways culminating in the up-regulation of anti-inflammatory cytokines $^{8_{4}}$. In this role PS acts also as an "innocent" signal suppressing an autoimmune response against the self-antigens of the apoptotic cell ${ }^{10-12}$.

Residing in living cells predominantly in membrane leaflets facing the cytosol, PS becomes exposed at the cell surface early after the onset of apoptosis ${ }^{13-15}$. It is believed that the surface-expressed PS elicits "eat me" and "innocent" signals from its interaction with the phagocyte. The interaction may occur either directly to a candidate PS-receptor (PSR) ${ }^{16}$ or via bridging molecules such as Gas- $6^{17}$, $\beta 2$-glycoprotein- $1^{18}$, protein $S^{19}, M F G-E 8^{20}$ and annexin $A 1^{21}$. However, recent PSR knockout experiments demonstrated that PSR is likely not involved in apoptotic cell clearance ${ }^{22}$.

The prominent role of PS in engulfment of apoptotic cells by various macrophages has been construed mainly from experiments using PSliposomes ${ }^{23}$ and the PS-binding protein annexin $A 5^{24}$. Recently, we showed that annexin A5 binds to the surface-expressed PS and causes internalization of the PS-expressing membrane patch and the embedded proteins, such as tissue factor $^{25_{1}} 26$. Having this novel insight, we took a closer look at the mechanism of annexin $A 5$ in the inhibition of engulfment of anti-Fas stimulated Jurkat cells by J774 macrophages. Using a novel flow cytometric-based phagocytosis assay, 
we demonstrate that the inhibitory action of annexin A5 is not based on the physical shielding of PS from its direct participation in engulfment but on the internalization of the PS-expressing membrane patch that harbors a complex collection of "eat me" signals. Our findings favor a model in which PS is not the main "eat me" signal but its externalization results in the appearance of other "eat me" signals within the PS-expressing membrane patch.

\section{RESULTS}

\section{VALIDATION OF THE FLOW CYTOMETRIC-BASED PHAGOCYTOSIS ASSAY.}

Flow cytometry is a useful technique to study phagocytosis of apoptotic cells by macrophages. J774 macrophages and Jurkat cells can be clearly distinguished by their forward/side scatter properties. We labeled Jurkat cells with the green fluorochrome CFSE (5,-6 carboxyfluorescein diacetate succinimidyl ester), which can be retained by cells for several weeks without affecting their viability ${ }^{28}$. It appeared that phagocytosis of CFSE $(5,-6$ carboxyfluorescein diacetate succinimidyl ester) labeled Jurkat cells induces a left shift of fluorescence compared with the fluorescence of free Jurkat cells as seen in the $\mathrm{Fl}-1$ versus $\mathrm{Fl}-3$ dot plot (Fig. 1a). We hypothesized that this was due to acidification of the phagolysosome that resulted in a $\mathrm{pH}$ induced shift of the spectral properties of the CFSE dye. To test whether phagocytosed CFSElabeled Jurkat cells were rapidly acidified in the phagocyte, annexin A5-CFSE was added to apoptotic Jurkat cells at various $\mathrm{pH}$ and analyzed by flow cytometry (Fig. 1b). We observed a decrease in the \% of maximal mean fluorescence intensity (MFI) of $\mathrm{Fl}-1$ at lower $\mathrm{pH}$ while the $\%$ of MFI of $\mathrm{Fl}-3$ was not significantly changed. This indicates that the shift in Fl-1 fluorescence is due to rapid acidification of the Jurkat cells when phagocytosed. In order to verify that the measured fluorescence in $\mathrm{J} 774$ cells was derived from the uptake of CFSE-labeled apoptotlc Jurkat cells and not from the uptake of CFSE-label that had leaked out of the Jurkat cell during the experiment, we performed a control experiment in which CFSE-labeled $\mathrm{J} 774$ were allowed to ingest unlabeled apoptotic Jurkat cells. This did not result in a left shift of the fluorescence as observed for unlabeled $\mathbf{J 7 7 4}$ that ingested CFSE-labeled apoptotic Jurkat cells (data not shown). Furthermore, the presence of engulfed apoptotic cells in the macrophages was confirmed by confocal scanning laser microscopy (CSLM) (Fig. 1c). The kinetics of phagocytosis of apoptotic Jurkat cells was independent of the apoptotic-inducing stimulus and revealed that the maximal response was achieved after $2 \mathrm{~h}$ of phagocytosis irrespective of the stimulus inducing cell death (Fig. 1d). We selected i) $2 \mathrm{~h}$ of incubation as a standard incubation time, 
ii) a serum concentration of $10 \%$ and iii) anti-Fas ligation to induce apoptosis in all further experiments.

a

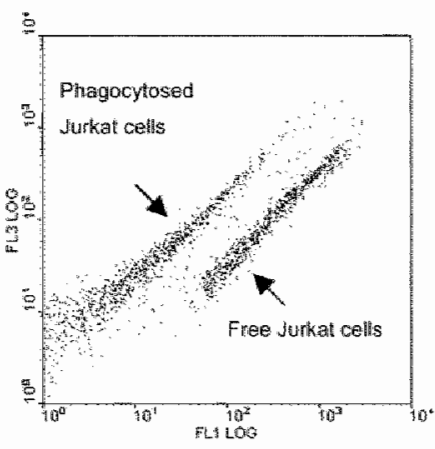

c

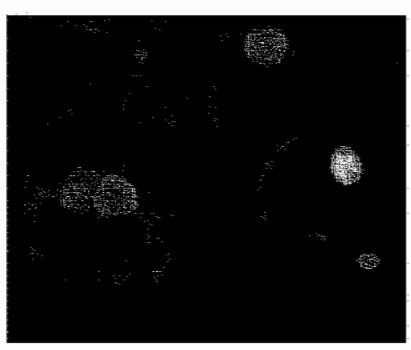

b

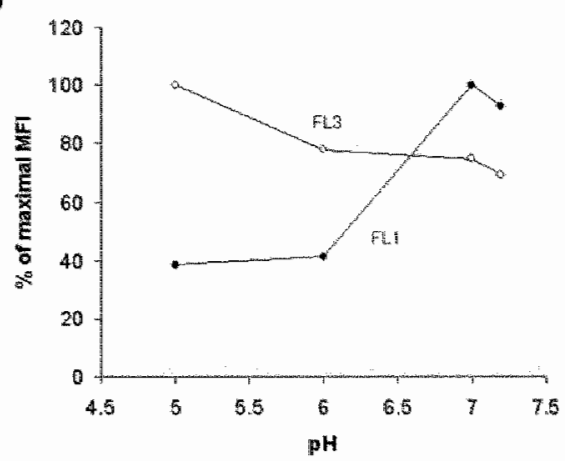

d

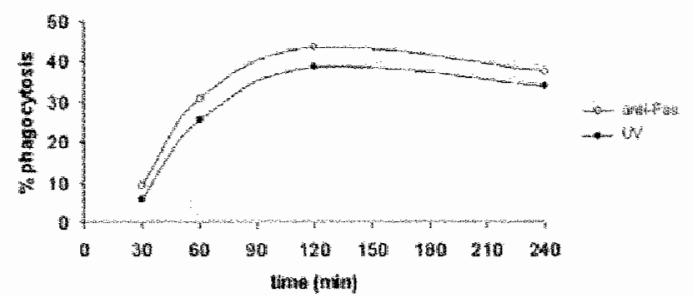

e

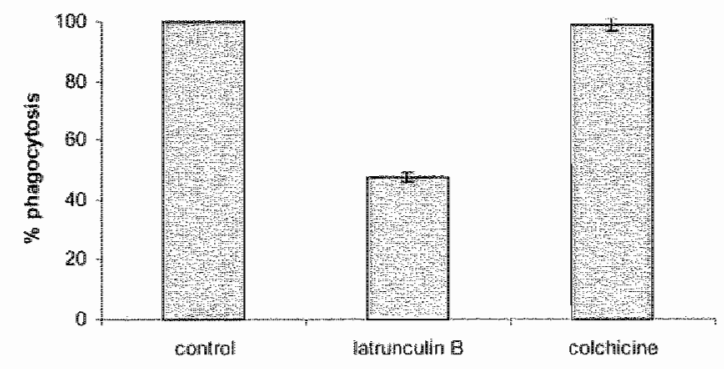

FIG. 1. Validation of the flow cytometric-based phagocytosis assay. (a) FI-1 fluorescence vs. FH-3 fluorescence dot plot reveals a shift in FL-1 fluorescence after phagocytosis of apoptotic cells. (b) The shift in FL-1 fluorescence is pH-clependent while the FL-3 fluorescence is not. (c) Confocal scanning laser microscopy (CSLM) of $\mathbf{J 7 7 4}$ that have phagocytosed CFSE-labeled apoptotic Jurkat cells and are stained for actin with Phalloidin-Texas Red. (d) A time course of the \% phagocytosis of Jurkat cells triggered to undergo apoptosis with either anti-Fas (open circles) or UV irradiation (filled circles). (e) $\%$ phagocytosis in the presence of cytoskeleton disrupting agents, latrunculin $B$ and colchicine. 
During the process of phagocytosis the macrophage forms filopodia to surround an apoptotic cell, which leads to an actin-dependent internalization of the apoptotic cell ${ }^{8,29}$. Latrunculin B (Sigma), an inhibitor of actin polymerization, inhibits the phagocytosis of apoptotic cells by $J 774$ macrophages as shown in Fig. 1e. Incubation of the $\mathbf{J 7 7 4}$ with colchicine, a microtubule disrupting agent has no effect on the phagocytosis of apoptotic Jurkat cells. These data confirm that our flow cytometric method indeed measures engulfment of apoptotic cells.

\section{ANNEXIN A5 INHIBITS THE ENGULFMENT OF APOPTOTIC CELLS WHEN PRESENT DURING THE EXECUTION OF APOPTOSIS.}

We employed the novel flow cytometric-based phagocytosis assay to explore further the role of PS in the engulfment process. Annexin A5 is a protein that binds with high affinity to PS and that has been shown to inhibit phagocytosis of apoptotic cells ${ }^{24,30,31}$. Addition of annexin A5 to $\mathbf{J 7 7 4}$ cells together with CFSElabeled apoptotic Jurkat cells resulted in approximately $20 \%$ inhibition of phagocytosis. If annexin A5 was added together with the anti-Fas stimulus to Jurkat cells the resulting apoptotic cells were less efficiently engulfed by the $\mathrm{J} 774$ cells (Fig. 2a). This inhibition cannot be explained by an interference of annexin A5 with the execution of apoptosis since we recently showed that the progression of apoptosis, including the surface expression of PS, is not hampered by the presence of annexin A5. Annexin A5 does inhibit the formation of apoptotic bodies ${ }^{26,}{ }^{32}$. The observed increased inhibition of phagocytosis could come from the possibility that $\mathrm{J} 774$ engulf apoptotic bodies more efficiently than apoptotic cells. This possibility was ruled out by using the ROCK-1 inhibitor Y-27632, which prevents apoptotic body formation but not PS exposure of anti-Fas stimulated Jurkat cells ${ }^{26},{ }^{33}$. Jurkat cells treated with antiFas in the presence of Y-27632 were as efficiently phagocytosed as Jurkat cells stimulated in the absence of the inhibitor (Fig. 2b).

Taking into account that Jurkat cells that have executed apoptosis in the presence of annexin A5 still express PS at their surface we reasoned that the annexin A5-induced internalization of PS-expressing membrane patches ${ }^{26}$ forms the basis for the observed inhibition of phagocytosis. 
a

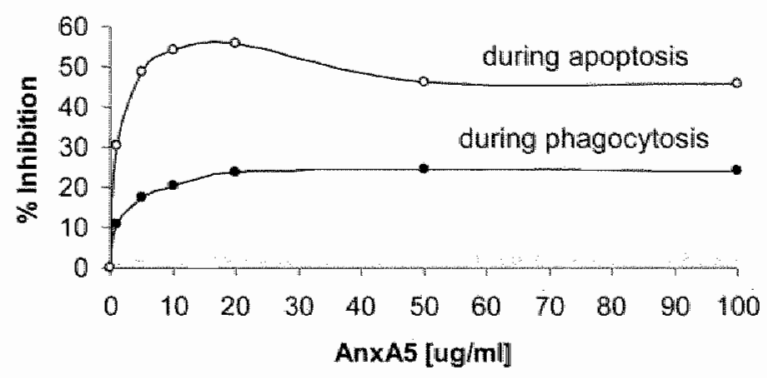

b

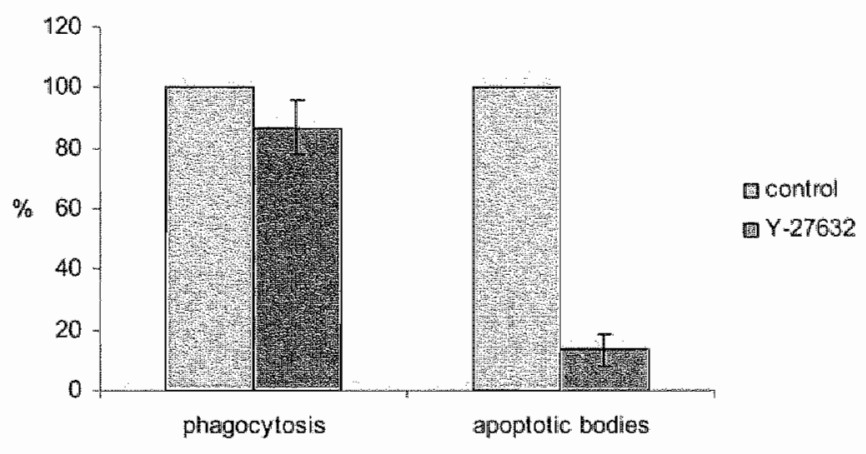

FIG. 2. Effect of annexin A5 on the phagocytosis of apoptotic cells. (a) Dose-response of annexin $\mathrm{A} 5$ added to cells during/after the execution of the apoptotic program. (b) $\%$ phagocytosis in the presence of a ROCK-1 inhibitor $(Y-27632)$ and the \% apoptotic body formation after $Y$-27632 administration.

\section{ANNEXIN A5 INDUCED INTERNALIIZATION OF PS-EXPRESSING MEMBRANE PATCHES INHIBITS THE ENGULFMENT OF APOPTOTIC CELLS.}

Previously, we showed that annexin A5 not only binds to apoptotic cells but affects the dynamics of the plasma membrane of the apoptotic cell without interfering with the major step of Fas triggered apoptosis ${ }^{26}$. When Jurkat cells are incubated with anti-Fas and concurrently with annexin A5-Alexa568 the Jurkat cells executing apoptosis internalize annexin A5-Alexa568 as measured by Confocal scanning laser microscopy (CSLM) (Fig. 3a). This internalization was not observed for M23, a mutant of annexin A5, and annexin A1. M23 binds to the surface of the apoptotic cell and instead of being internalized it enhances bleb formation (Fig. 3b). Annexin A1, which is another PS binding protein from the annexin family, also binds to the surface of apoptotic cells without being internalized (Fig. 3c). Interestingly, annexin A5 shuttles annexin A1 into the cell (Fig. 3d), demonstrating that annexin A5 internalizes proteins that are bound to 
or in the vicinity of PS. The latter has been demonstrated for tissue factor, which is internalized in PS-expressing cells by annexin $A 5^{25}$.

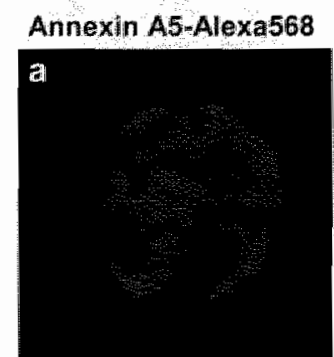

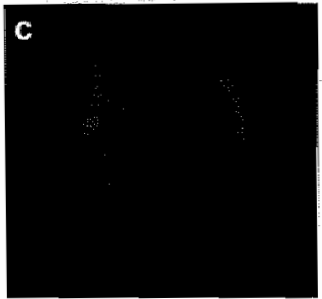

Anmexin A1-Alexa568

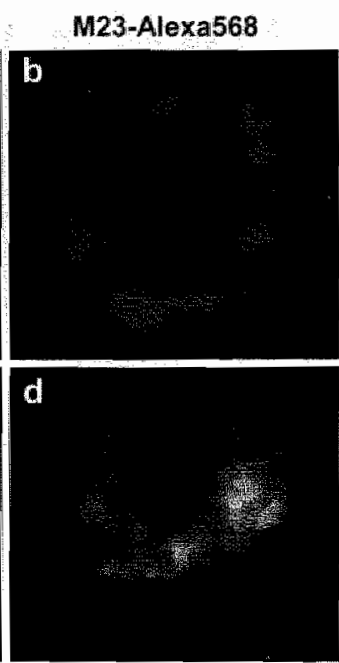

Annexin A5-OG Annexin A1-Alexa568

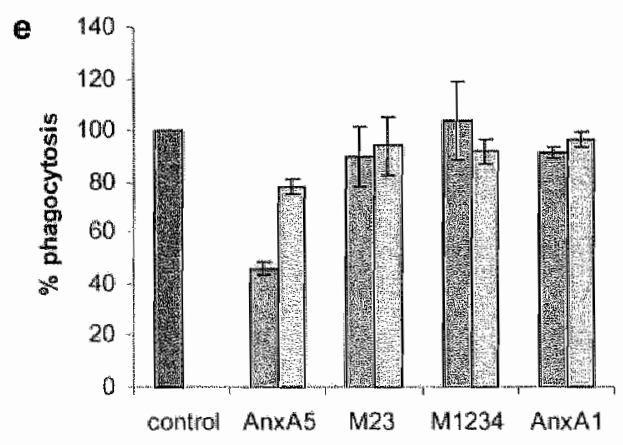

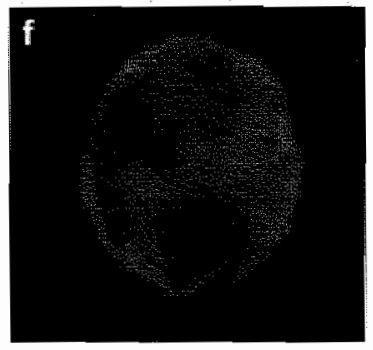

Annexin A5-Alexa568/ Annexin A5-OG

FIG. 3. The specificity of annexin $A 5$ to inhibit the phagocytosis of cells undergoing apoptosis. (a) CSLM of anti-Fas treated Jurkat cells in the presence of $20 \mu \mathrm{g} \mathrm{ml}^{-1}$ annexin A5-Alexa568. (b) CSLM of anti-Fas treated Jurkat cells in the presence of $20 \mu \mathrm{g}$ $\mathrm{ml}^{-1} \mathrm{M} 23$-Alexa568. (c) CSLM of anti-Fas treated Jurkat cells in the presence of $20 \mu \mathrm{g}$ $\mathrm{ml}^{-11}$ annexin A1-Alexa568. (d) CSLM of anti-Fas treated Jurkat cells in the presence of $20 \mu \mathrm{g} \mathrm{ml} l^{-1}$ annexin A5-Oregon Green and $20 \mu \mathrm{g} \mathrm{ml} l^{-1}$ annexin A1-Alexa568. (e) \% phagocytosis of apoptotic cells in the presence of annexin A5, M23, M1234 and annexin A1. (f) CSLM of anti-Fas treated Jurkat cells in the presence of $20 \mu \mathrm{g} \mathrm{ml}{ }^{-1}$ annexin A5Alexa568 and counterstained with $250 \mathrm{ng} \mathrm{ml}^{-1}$ annexin A5-Oregon Green. 
To investigate whether shielding of PS by annexin A5 or internalization of the PS-expressing membrane patch is responsible for the inhibition of phagocytosis we studied the effects of M23, M1234 and annexin A1 on phagocytosis. These proteins show an inhibitory effect neither when added at the start of phagocytosis nor when added at the start of apoptosis (Fig. 3e).

In order to clarify the role of surface expressed PS further we incubated Jurkat cells with anti-Fas in the presence of annexin A5-Alexa568. Following the incubation period the cells were washed with EDTA to remove surface bound annexin A5-Alexa568. Incubating these cells with annexin A5-Oregon Green and analyzing them by CSLM revealed that these cells still expressed PS at their cell surface after internalization (Fig. $3 f$ ). These results indicate that the ability of annexin A5 to inhibit phagocytosis indeed depends on its PS-binding capacity. However, the inhibition is not caused by shielding of PS but by internalization of the PS-expressing membrane patch.

Taken together, our data indicate that the uptake of apoptotic cells relies on the surface expression of PS, however, not in a manner involving a direct interaction between PS and a phagocytic receptor but via the generation of a membrane patch with other "eat me" features, which have to be identified.

\section{MATERIALS AND METHODS}

\section{CLONING, EXPRESSION, PURIFICATION AND LABELING OF ANNEXIN A5 AND ITS CALCIUM BINDING SITE MUTANTS, M23 AND M1234}

cDNA encoding for the annexin A5 mutant M1234 (E72D, D144N, E228A and D303N) having four defective calcium binding sites was kindly provided by Prof. Dr. F. Russo-Marie (BIONEXIS-Pharmaceuticals, France). The M1234 cDNA was recloned to remove the $5^{\prime}$ basepairs responsible for the 3 extra $\mathrm{N}$-terminal amino acids after expression ${ }^{27}$. The annexin A5 mutants M23 and M1234 CDNA's were cloned into the bacterial expression vector pET-5a (Novagen). Proteins were expressed in $E$. Coli and purified to homogeneity as assessed by silver stained SDS-PAGE and Western blotting. Annexin A5 and its mutants were labeled with fluorescein-isothiocyanate (FITC), Oregon Green (OG), 5,-6 carboxyfluorescein diacetate succinimidyl ester (CFSE) and Alexa568succinimidylester according to the protocols of Molecular Probes (Eugene, USA). The labeled proteins with 1:1 stoichiometry were purified from the mixtures by MonoQ chromatography with Äcta Explorer (Amersham-Pharmacia, Upsala, Sweden). 


\section{CELL CULTURE}

J774 mouse macrophages (ATCC) were cultured in DMEM with glutamax (Gibco BRL) supplemented with 100 units $\mathrm{ml}^{-1}$ penicillin, $0.1 \mathrm{mg} \mathrm{ml}^{-1}$ streptomycin, and $10 \%$ heat-inactivated fetal bovine serum (PAA Laboratories $\mathrm{GmbH}$ ). The T-lymphoma cell line Jurkat (ATCC) was grown in RPMI 1640 medium (Gibco BRL), containing 100 units $\mathrm{ml}^{-1}$ penicillin, $0.1 \mathrm{mg} \mathrm{ml}^{-1}$ streptomycin, and $10 \%$ heat-inactivated fetal bovine serum.

\section{BINDING ASSAY OF ANNEXIN A5-CFSE TO APOPTOTIC JURKAT CELLS AT VARIOUS PH}

Jurkat cells $\left(1 \times 10^{6}\right.$ cells $\left.\mathrm{ml}^{-1}\right)$ in $\mathrm{M} 199$ medium supplied with $0.5 \mathrm{mM} \mathrm{CaCl}_{2}$ were stimulated either with ionomycine $(5 \mu \mathrm{M})$ for $5 \mathrm{~min}$ or with anti-Fas antibody (200 $\mathrm{ng} \mathrm{ml}^{-1}$ ) for $3 \mathrm{~h}$. Annexin A5-CFSE $10 \mu \mathrm{g} \mathrm{ml}^{-1}$ was added to a $\mathrm{Ca}^{2+}$-buffer (10 $\mathrm{mM}$ Hepes, $150 \mathrm{mM} \mathrm{NaCl}, 5 \mathrm{mM} \mathrm{KCl}, 1 \mathrm{mM} \mathrm{MgCl}, 2.5 \mathrm{mM} \mathrm{CaCl}_{2}$ ) with varying $\mathrm{pH}$ containing $1 \times 10^{5}$ apoptotic cells. The cells were incubated for $5 \mathrm{~min}$ on ice and then measured on a Coulter Epics XL-MLC ${ }^{T M}$ flow cytometer. The mean fluorescence intensity (MFI, arbitrary units) was calculated off-line with WinMDI 2.8 (free share software designed by Joseph Trotter) for the CFSE signal.

\section{FLOW CYTOMETRIC-BASED PHAGOCYTOSIS ASSAY}

Phagocytosis of apoptotic Jurkat cells by $\mathrm{J} 774$ mouse macrophages was assayed by flow cytometry. Jurkat cells $\left(10^{6}\right.$ cells $\left.\mathrm{mll}^{-1}\right)$ were pre-incubated for 10 min with CFSE $(2.5 \mu \mathrm{M})$. Subsequently, the cells were treated with or without

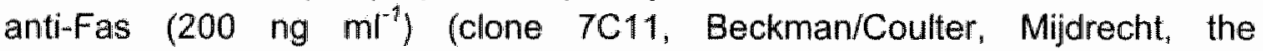
Netherlands) and annexin A5, M23, M1234 or annexin A1 when indicated. $J 774$ macrophages were treated with $0.5 \mu \mathrm{M}$ latrunculin $B$ and $1 \mu \mathrm{M}$ colchicine $1 \mathrm{~h}$ prior to the addition of apoptotic Jurkat cells when indicated. $J 774$ cells were plated in 12-well plates at $5.5 \times 10^{5}$ cells/well one day before phagocytosis. Phagocytosis was started by adding the treated Jurkat cells without washing to the plated $\mathrm{J} 774$ cells at a ratio of $2: 1$. After $2 \mathrm{~h}$ of phagocytosis the $\mathrm{J} 774$ cells were washed three times with phosphate-buffered saline (PBS), scraped in $1 \mathrm{ml}$ PBS, and subsequently analyzed for fluorescence by a Coulter Epics XL-MLC ${ }^{T M}$ flow cytometer. Fl-1 fluorescence was plotted against the Fl-3 fluorescence and off-line calculation of the \% of R1 gated $\mathrm{J} 774$ that have internalized apoptotic cells was calculated. Off-line analysis of the flow cytometer files was performed with WinMDI 2.8 (free share software designed by Joseph Trotter). 


\section{CONFOCAL SCANNING LASER MICROSCOPY (CSLM)}

J774 cells were plated on glass cover slips one day before phagocytosis. Next day, the Jurkat cells were induced to undergo apoptosis for $3 \mathrm{~h}$ with anti-Fas (200 $\mathrm{ng} \mathrm{m} \mathrm{m}^{-1}$ ) in the presence and absence of annexin A5-Oregon Green (25 $\mathrm{\mu g}$ $\mathrm{ml}^{-1}$ ). Jurkat cells were seeded on the $\mathrm{J} 774$ and annexin A5-Oregon Green was added if indicated. After $2 \mathrm{~h}$ of phagocytosis, the $J 774$ cells were washed with PBS. Subsequently, the cells were fixed for $10 \mathrm{~min}$ in $4 \%$ paraformaldehyde in $\mathrm{Ca}^{2+}$-buffer (10 $\mathrm{mM}$ Hepes, $150 \mathrm{mM} \mathrm{NaCl}, 5 \mathrm{mM} \mathrm{KCl}, 1 \mathrm{mM} \mathrm{MgCl}, 2.5 \mathrm{mM}$ $\left.\mathrm{CaCl}_{2}, \mathrm{pH} 7.4\right)$. J774 cells were stained for actin with Phalloidin-Texas Red (1:250) according to the manufacturing protocol (Molecular Probes). The cover slips were put on a slide containing a drop of $90 \%$ glycerol in $0.02 \mathrm{M} \mathrm{Tris}-\mathrm{HCl}$ $\mathrm{pH} 8.0$ with addition of $2 \%$ 1,4-diazobicyclo-[2,2,2]-octane (DABCO, Merck). Slides were examined with a confocal scanning laser microscope (CSLM, Bio Rad laboratories) equipped with a Crypton/Argon mixed gas laser (lon Laser Technology. Salt Lake city, USA) with two separate wavelengths for the excitation at $488 \mathrm{~nm}$ and $568 \mathrm{~nm}$. Images were recorded and analyzed with $\mathrm{N} \| \mathrm{H}$ image, ImageJ software and Abdobe Photoshop.

\section{DISCUSSION}

Apoptosis and subsequent clearance of apoptotic cells by macrophages play a major role in diseases. Therefore, it is essential to understand the mechanisms underlying the biology of phagocytic clearance of apoptotic cells. To date, the best characterized "eat me" signal on the apoptotic cell surface is PS" ${ }^{23,34}$. Direct interaction of PS with the PS receptor (PSR) was thought to play a critical role in the uptake of the apoptotic cell while other receptors on the macrophage are responsible for tethering the apoptotic cell to the macrophage ${ }^{9}$. Both activated and unactivated macrophages recognize PS, but with different receptor systems ${ }^{24,31}$. The uptake of apoptotic cells by unactivated macrophages, such as murine $\mathbf{1 7 7 4}$ macrophages, is inhibited by lipid-symmetric erythrocytes but not by PS vesicles, while activated macrophages are inhibited by PS vesicles but not by lipid-symmetric erythrocytes. This discrepancy suggests that the exclusive role of PS in the uptake of apoptotic cells is still unclear. Furthermore, loss of phospholipid asymmetry, with consequent exposure of PS in the outer leaflet of the plasma membrane, appears not onlly to be a key feature of apoptosis but also plays an important role in several other biological processes. PS exposure has been reported in living cells. For example, murine bone marrow B cells expose PS without executing apoptosis ${ }^{35}$. During fusion of 
myoblasts to form multinucleated myotubes ${ }^{36,37}$ and during fusion of cytotrophoblast cells to form the syncitiotrophoblast of the placental chorionic villi ${ }^{36}$, temporarily exposed PS may be required to facilitate the fusion process. In these cells, PS exposure has obviously no "eat me" signal. Appelt et al. suggested that the PS density is too low to induce the "eat me" signal ${ }^{39}$. In this paper, we show that the externalized PS is not likely to be the "eat me" signal. In apoptotic cells, the PS expressing membrane patch harbors the "eat me" signals that trigger engulfment.

Annexin A5 binds with high affinity and selectively to PS, which is exposed on the surface of apoptotic cells ${ }^{40}$. Binding of annexin A5 to externalized PS has been reported to completely inhibit phagocytosis of apoptotic cells by both activated and unactivated macrophages ${ }^{24}$. Our data show on the contrary that PS externalization is not the main target in the uptake of apoptotic cells by macrophages. We clearly show that when annexin A5 is administered after the execution of apoptosis only a mild inhibition of clearance of apoptotic celis by macrophages was seen. Moreover, when annexin A5 was present during the process of apoptosis, a more than $50 \%$ inhibition of phagocytosis was observed. Recently, we demonstrated that annexin A5 mediates the internalization of PS-expressing membrane patches when present during the process of apoptosis ${ }^{26}$ and downregulates proteins embedded in this membrane patch, such as tissue factor ${ }^{25}$. In contrary, Krahling et al. did not observed internalization of annexin A5 when bound to the lymphocyte surface. Although not reported, we assume that they added annexin A5 to cells that had fully completed the apoptotic program and did not looked into the dynamics of the apoptotic process in the presence of annexin A5. Taken together, our data indicate that annexin A5 not only inhibits phagocytosis specifically just by shielding PS but also non-specifically by internalizing receptors/ligands on the apoptotic target cell that are in the vicinity of PS. Therefore, it seems that the direct interaction of PS with the PS receptor is not as essential as has been asserted in the past ${ }^{22}$ but acts in conjunction with other molecules that appear on the apoptotic cell surface together with PS to create a complex recognition signal $^{24,41}$. Together with our previously reported data that annexin A5 not only binds to exposed PS but induces its own internalization, we conclude that annexin A5 downregulates surface expression of ligands embedded in the PSexpressing membrane domain which participate in the recognition and subsequent clearance of apoptotic cells. The recent data of Ravassa et al. that annexin A5 downregulates tissue factor expression from the surface of apoptotic cells through the mechanism of internalization supports this mechanism. 
In conclusion, our data show that PS-exposing cells can be rescued from being engulfed if annexin A5 is present at the beginning of the process of apoptosis. This is dependent on annexin A5-mediated internalization of PS-positive membrane patches, and not on PS - PS receptor signaling alone. Our results certainly explain why the search for the PS-receptor is cumbersome and still without success. We postulate that annexin A5 downregulates surface expression ligands that are located in the vicinity of PS. This mechanism may play a role in the prevention of the engulfment of PS-expressing living cells.

\section{ACKNOWLEDGMENTS}

Annexin A1 was kindly provided by Dr. E. Solito (London, UK). Parts of this study were made possible by the Dutch Organization for Scientific Research (NWO) grants 902-26184, 014-80-103 and 912-03-013. Correspondence and requests for materials should be addressed to C.P.M.R. 


\section{REFERENCES}

1. Leist $M_{3}$ Jaattela $M_{\text {}}$ Four deaths and a funeral: from caspases to alternative mechanisms. Nat Rev Mol Cell Biol, 2001; 2: 589-598.

2. Voll RE, Herrmann $M$, Roth EA, Stach $C$, Kalden JR, Girkontaite I, Immunosuppressive effects of apoptotic cells. Nature, 1997; 390:350-351.

3. Fadok VA, Bratton DL, Konowal A, Freed PW, Westcolt JY, Henson PM, Macrophages that have ingested apoptotic cells in vitro inhibit proinflammatory cytokine production through autocrine/paracrine mechanisms involving TGF-beta, PGE2, and PAF. J Clin Invest, 1998; 101: 890-898.

4. Huynh ML, Fadok VA, Henson PM, Phosphatidylserine-dependent ingestion of apoptotic cells promotes TGF-beta1 secretion and the resolution of inflammation. $J$ Clin Invest, 2002; 109: 41-50.

5. Wyllie $\mathrm{AH}$, Kerr JF, Currie $A R_{\text {, }}$ Cell death: the significance of apoptosis. Int Rev Cytol, $1980 ; 68: 251-306$.

6. Savill J, Fadok V, Corpse clearance defines the meaning of cell death. Nature, 2000; 407: 784-788.

7. Lauber K, Blumenthal SG, Waibel M, Wesselborg S, Clearance of apoptotic cells: getting rid of the corpses. Mol Cell, 2004; 14: 277-287.

8. Hoffmann PR, deCathelineau AM, Ogden $\mathrm{CA}_{\text {, }}$ Leverrier $Y$, Bratton DL, Daleke DL, Ridley AJ, Fadok VA, Henson PM, Phosphatidylserine (PS) induces PS receptormediated macropinocytosis and promotes clearance of apoptotic cells. $J$ Cell Biol, 2001; 155: 649-659.

9. Somersan $S$, Bhardwaj $N_{n}$ Tethering and tickling: a new rolle for the phosphatidylserine receptor. I Cell Biol, 2001; 155: 501-504.

10. Stach CM, Turnay X, Voll RE, Kern PM, Kolowas W, Beyer TD, Kalden JR, Herrmann $M$, Treatment with annexin $V$ increases immunogenicity of apoptotic human T-cells in Balb/c mice. Cell Death Differ, 2000; 7: 911-915.

11. Gaipl US, Beyer TD, Baumann I, Voll RE, Stach CM, Heyder P, Kalden JR, Manfredi $A$, Herrmann $M_{s}$. Exposure of anionic phospholipids serves as antiinflammatory and immunosuppressive signal--implications for antiphospholipid syndrome and systemic lupus erythematosus. Immunobiology, 2003; 207: 73-81.

12. Asano $K_{n}$ Miwa $M$, Miwa $K$, Hanayarna $R$, Nagase $H$, Nagata $S$, Tanaka $M$, Masking of phosphatidylserine inhibits apoptotic cell engulfment and induces autoantibody production in mice. $J$ Cell Biol, $2004 ; 166: 13$.

13. Zwaal RF, Schroit AJ, Pathophysiologic implications of membrane phospholipid asymmetry in blood cells. Blood, 1997; 89: 1121-1132.

14. Fadok VA, Voelker DR, Campbell PA, Cohen JJ, Bratton DL, Henson PM, Exposure of phosphatidylserine on the surface of apoptotic lymphocytes triggers specific recognition and removal by macrophages. J Immunol, 1992; 148: 2207 . 2216.

15. Martin SJ, Reutelingsperger CP, McGahon AJ, Rader JA, van Schie RC, LaFace DM, Green DR, Early redistribution of plasma membrane phosphatidylserine is a general feature of apoptosis regardless of the initiating stimulus: inhibition by overexpression of Bcl-2 and Abl. J Exp Med, 1995; 182: 1545-1556. 
16. Fadok VA, Bratton DL, Rose DM, Pearson A, Ezekewitz RA, Henson PM, A receptor for phosphatidylserine-specific clearance of apoptotic cells. Nature, 2000 ; 405: 85-90.

17. Ishimoto $Y$, Ohashi $K$, Mizuno $K$, Nakano T, Promotion of the uptake of PS liposomes and apoptotic cells by a product of growth arrest-specific gene, gast. I Biochem (Tokyo), 2000; 127: 411-417.

18. Balasubramanian $K$, Chandra $J$, Schroit $A J$, Immune clearance of phosphatidytserine-expressing cells by phagocytes. The role of beta2-glycoprotein in macrophage recognition. J Biol Chem, 1997:272: 31113-31117.

19. Anderson HA, Maylock CA, Williams JA, Paweletz CP, Shu H, Shacter E, Serum derived protein $S$ binds to phosphatidy/serine and stimulates the phagocylosis of apoptotic cells. Nat Immunol, 2003; 4: 87-91.

20. Hanayama $R_{0}$ Tanaka $M$, Miwa $K$, Shinohara $A$, wamatsu $A$, Nagata $S$. Identification of a factor that links apoptotic cells to phagocyles. Nature, $2002 ; 417$ : 182-187.

21. Arur $S$, Uche UE, Rezaul $K$, Fong $M$, Scranton $V$, Cowan $A E$, Mohler $W$, Han DK, Annexin $I$ is an endogenous ligand that mediates apoptotic cell engulfment. Dev Cell, 2003; $4: 587-598$.

22. Bose J, Gruber AD, Helming $L$, Schiebe $S$, Wegener 1 , Hafner $M$, Beales $M$, Kontgen $F$, Lengeling $A$, The phosphatidylserine receptor has essential functions during embryogenesis but not in apoptotic cell removal. J Biol, 2004; 3: 15.

23. Fadok VA, de Cathelineau A, Daleke DL, Henson PM, Bratton DL, Loss of phospholipid asymmetry and surface exposure of phosphatidylserine is required for phagocytosis of apoptotic cells by macrophages and fibroblasts. I Biol Chem, 2001; $276: 1071-1077$.

24. Krahling $S$, Callahan MK, Williamson $P_{1}$ Schlegel RA, Exposure of phosphatidylserine is a general feature in the phagocytosis of apoptotic Iymphocytes by macrophages. Cell Death Differ, 1999; 6:183-189.

25. Ravassa $S$, Bennaghmouch $A$, Kenis $H$, Lindhout $T$, Hackeng $T$. Narula J, Hofstra $L$, Reutelingsperger $C$, Annexin A5 Down-regulates Surface Expression of Tissue Factor: a novel mechanism of regulating the membrane receptor repertoir. I Biol Chem, 2005; 280: 6028-6035.

26. Kenis $H$, van Genderen $H$, Bennaghmouch $A$, Rinia HA, Frederik $P$, Narula $J_{1}$ Hofstra L, Reutelingsperger CP, Cell surface-expressed phosphatidylserine and annexin A5 open a novel portal of cell entry. J Biol Chem, 2004; 279: 52623-52629.

27. Mira JP, Dubois T, Oudinet JP, Lukowski S, Russo-Marie F, Geny B, Inhibition of cytosolic phospholipase A2 by annexin $V$ in differentiated permeabilized HL-60 cells. Evidence of crucial importance of domain I type II Ca2+-binding site in the mechanism of inhibition. J Biol Chem, 1997; 272: 10474-10482.

28. Weston SA, Parish CR, New fluorescent dyes for lymphocyte migration studies. Analysis by flow cytometry and fluorescence microscopy. J Immunol Methods, 1990; 133: 87-97.

29. Coleman ML, Olson MF, Rho GTPase signalling pathways in the morphological changes associated with apoptosis. Cell Death Differ, 2002; 9: 493-504.

30. Callahan MK, Halleck MS, Krahling S, Henderson AJ, Williamson P, Schlegel RA, Phosphatidylserine expression and phagocytosis of apoptotic thymocytes during differentiation of monocytic cells. J Leukoc Biol, 2003; 74: 846-856. 
31. Callahan MK, Williamson $P$, Schlegel RA, Surface expression of phosphatidyiserine on macrophages is required for phagocytosis of apoptotic thymocytes. Cell Death Differ, 2000; 7: 645-653.

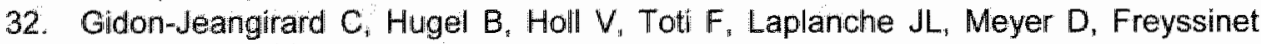
$J_{M}$ "Annexin $V$ delays apoptosis while exerting an external constraint preventing the release of $\mathrm{CD} 4+$ and PrPct membrane particles in a human $\mathrm{T}$ lymphocyte model. Jimmunol, 1999; 162; 5712-5718.

33. Coleman ML, Sahail EA, Yeo $M$, Bosch $M$, Dewar $A$, Olson MF, Membrane blebbing during apoptosis results from caspase-mediated activation of ROCK I. Nat Cell Biol, 2001; 3: 339-345.

34. Fadok VA, Bratton DL, Frasch SC, Warner ML, Henson PM, The role of phosphatidy/serine in recognition of apoptotic cells by phagocytes. Cell Death Differ, 1998; 5: 551-562.

35. Dillon $\mathrm{SR}$, Constantinescu $\mathrm{A}$, Schlissel MS, Annexin $\mathrm{V}$ binds to positively selected B cells. J Immunol, 2001; 166: 58-71.

36. Sessions A, Horwitz AF, Differentiation-related differences in the plasma membrane phospholipid asymmetry of myogenic and fibrogenic cells. Biochim Biophys Acta, 1983; 728: 103-111.

37. van den Eijnde $S M$, van den Hoff $M J$, Reutelingsperger $C P$, van Heerde $W L$, Henfling ME, Vermeij-Keers $C$, Schutte B, Borgers M, Ramaekers FC, Transient expression of phosphatidylserine at cell-cell contact areas is required for myotube formation. J Cell Sci, 2001; 114: 3631-3642.

38. Adler $R_{\mathrm{i}} \mathrm{Ng} \mathrm{AK}$, Rote NS, Monoclonal antiphosphatidylserine antibody inhibits intercellular fusion of the choriocarcinoma line, JAR. Biol Reprod, 1995; 53: 905910.

39. Appelt U, Sheriff A, Gaipl US, Kalden JR, Voll RE, Herrmann M, Viable, apoptotic and necrotic monocytes expose phosphatidylserine: cooperative binding of the ligand Annexin $V$ to dying but not viable cells and implications for PS-dependent clearance. Cell Death Differ, 2005; 12: 194-196.

40. Koopman G, Reutelingsperger CP, Kuijten GA, Keehnen RM, Pals ST, van Oers $\mathrm{MH}_{1}$ Annexin $\mathrm{V}$ for flow cytometric detection of phosphatidylserine expression on $\mathrm{B}$ cells undergoing apoptosis. Blood, 1994; 84: 1415-1420.

41. Devitt $A$, Pierce $S$, Oldreive $C$, Shingler WH, Gregory CD, CD14-dependent clearance of apoptotic cells by human macrophages: the role of phosphatidylserine. Cell Death Differ, 2003; 10: 371-382. 


\section{GENERAL DISCUSSION}

Annexin A5 was originally discovered as an anticoagulant protein ${ }^{1}$ with an antithrombotic activity in vivo ${ }^{2}$. This anticoagulant activity is due to its high affinity binding to phosphatidylserine (PS). Annexin A5 is present in the circulation and as such may effect blood coagulation. Disturbance of the haemostatic balance between pro-coagulant factors which promote blood coagulation, and those which act as anticoagulants often leads to the pathogenesis of several diseases, such as arterial and venous thrombosis. Accordingly, genetically caused defects in annexin A5 may be a genetic risk factor for thrombotic disorders. In the FIRST part of this discussion, we will speculate on the potential role of annexin A5 in the antithrombotic arm of the haemostatic balance.

So far, annexin A5 was thought to interfere with membrane-associated processes by binding to PS only. In the SECOND part of this discussion, we will explain that the function of annexin A5 goes further than only shielding PS. Since PS exposure plays a key role in several membrane-associated processes like blood coagulation, apoptosis, phagocytosis, cell fusion and differentiation, additional biological functions for annexin A5 in those processes may be envisioned.

\section{ROLE OF ANNEXIN A5 IN THROMBOSIS AND HAEMOSTASIS}

In CHAPTER 2 we obtained more insight in the physiological significance of annexin A5 in cardiovascular diseases by a genetic approach. Genetic alterations are often associated with diseases. Since annexin A5 is an anticoagulant protein with an antithrombotic activity in vivo, a possible role for annexin $A 5$ in the antithrombotic arm of the haemostatic balance has been proposed. From the data presented in chapter 2 , we conclude that the $\mathrm{C}-1 \mathrm{~T}$ mutation in the annexin A5 gene plays no role in the etiology of venous thrombosis but may be associated with an increased risk for myocardial infarction, especially in young men and in combination with coagulation defects such as factor $V$ Leiden and the prothrombin 20210A mutation ${ }^{4}$. This indicates the existence of a relationship between annexin A5 and arterial thrombosis. 


\section{ANNEXIN A5 LEVELS IN PLASMA AS A MARKER FOR ARTERIAL THROMBOSIS?}

The annexin A5 levels in plasma change under pathophysiological conditions. Increased plasma levels of annexin A5 are observed in patients with acute myocardial infarction ${ }^{5}$, cardiac arrest and severe trauma ${ }^{6}$ and reflect the severity of the damage of the myocardium. In this regard, annexin A5 levels in plasma could be used as a marker for the severity of myocardial injury. However, the annexin A5 levels are increased in several diseases, which may lead to low specificity for diagnosis of myocardial infarction.

The annexin A5 levels in plasma can also change by an altered expression profile in the annexin A5 gene caused by a mutation. González-Conejero found higher plasma levels of annexin A5 in patient carrying the C-1T mutation ${ }^{7}$. They proposed that increased levels of annexin A5 in plasma might protect against thrombosis by binding to negatively charged phospholipids exposed on platelet surfaces during activation. In line with this, they showed that the C-1T mutation reduces the risk of myocardial infarction at young age. In contrast, we found a slightly increased risk of myocardial infarction in patients with the C-1T mutation $^{4}$. These results indicate that a relationship between the $\mathrm{C}-1 \mathrm{~T}$ mutation and arterial thrombosis is present. However, the correlation between altered plasma levels and the C-1T mutation still remains unclear, since van Heerde et al. showed that the C-1T mutation does not affect plasma levels of annexin $A 5^{8}$. in conclusion, more studies have to be performed to define a relation between the levels of annexin A5 in plasma and the risk of thrombosis.

Based on observations that show enhanced thrombus formation in patients with anti-phospholipid antibodies, a role for annexin A5 as an anti-phospholipid antibody disrupting agent has been suggested ${ }^{9-40}$.

\section{ANNEXIN A5 AS AN ANTIPHOSPHOLIPID ANTIBODY DISRUPTING AGENT?}

Rand et al. showed that displacement of annexin A5 from the placental villi by anti-phospholipid antibodies is responsible for thrombosis and pregnancy loss in patients with the anti-phospholipid antibody syndrome ${ }^{11}$. However, Bevers et al. were unable to displace annexin A5 from a phospholipid model membrane by anti-phospholipid antibodies ${ }^{12}$. Moreover, van Heerde et al. found no correlation between the presence of anti-phospholipid antibodies and a history of thromboembolic complications ${ }^{13}$. Based on these observations, they conclude that displacement of annexin A5 from cellular surfaces by anti-phospholipid antibodies is not a common mechanism in patients with anti-phospholipid antibodies. The question still remains whether anti-annexin $A 5$ antibodies are 
able to remove annexin A5 from cellular surfaces in vivo. Recently, Aral et all. postulate that anti-annexin A5 antibodies reduce the availability of annexin A5 for binding to the phospholipid surface rather then interfering with the binding of anti-phospholipid antibodies to the phospholipid surface ${ }^{14}$. This hypothesis was based on the observation that the antibodies bound to free/unbound amexin A5 rather than phospholipid-bound annexin A5. As the PS-bound annexin A5 is not a target for the patients" anti-annexin A5 antibodies, a pathogenic role for these antibodies must be limited to the free form of annexin A5.

PS exposure is not only a general feature for the initiation of blood coagulation but is also an early marker for the initiation of the cell death program. In this regard, annexin A5 could also play an essential role as an anti-thrombotic agent during apoptosis.

\section{ANNEXIN A5 AS AN ANTI-THROMBOTIC AGENT DURING APOPTOSIS?}

The antithrombotic activity of annexin $A 5$ is not restricted to blood coagulation but occurs also at the surface of apoptotic celis. Annexin A5 binding to the plasma cell membrane of apoptotic cells leads to a decrease in the thrombogenic properties of the cell surface of apoptotic cells. Annexin A5 cownregulates tissue factor activity of apoptotic vascular smooth muscle cells thereby reducing the thrombogenicity of apoptotic cells by opening a novel portal of cell entry ${ }^{15}$ (see also Chapter 4). This activity depends on the crystallization property of annexin A5. We also found that annexin A5 inhibits apoptolic body formation during the process of apoptosis. However, shielding of PS alone was not sufficient to inhibit apoptotic body formation. These data indicate that annexin A5 acts as an antithrombotic agent at three levels: i) down-regulation of surface receptors such as tissue factor through activating the PS-annexin A5 pinocytic pathway, ii) inhibition of thrombin formation through shielding of PS and iii) inhibition of dissemination of thrombotic membranes through 2D-crystallization.

\section{ROLE OF ANNEXIN A5 IN CELL MEMBRANE BIOLOGY}

In CHAPTER 3, we studied the relationship between the point of no return in the cell death program and the externalization of PS by using the annexin A5 imaging technique. It has always been thought that once the process of cell suicide has passed a certain point, it is irreversible, and that the point of no return is marked by the expression of PS at the cell surface. Our data show that 
cardiomyocytes destined to die recover from the initiation of the cell death program upon restoration of blood flow, despite the activation of caspase 3 .

We also observed that PS exposure is a continuous process. In this regard, the reversible PS exposure constitutes an attractive target for non-invasive detection of myocardial ischemia as a "hot-spot" imaging agent in addition to stress myocardial perfusion imaging. Furthermore, persistence of PS externalization for at least 24 hours after ischemic stress gives us an indication of the time window for diagnostic and therapeutic use of annexin A5.

Another interesting feature we observed is that annexin A5 binding to PS leads to the internalization of annexin A5 in endocytic vesicles of the cardiomyocyte. This observation formed the basis for the discovery of a novel portal of cell entry (Chapter 4). This discovery appears to have a major impact on our conception of the biological significance of annexin A5 as will be outlined further below.

In CHAPTER 4, we have analyzed the mechanism of the observed internalization of annexin A5. We clearly show that annexin A5 changes the cell membrane dynamics of PS-exposing cells. So far, annexin A5 was thought to interfere with membrane-associated processes by binding to PS only. However, we demonstrate that the function of annexin A5 goes further than only shielding PS. Our studies reveal that annexin A5 internalizes PS-expressing membrane patches through its $2 \mathrm{D}$-crystallization at the surface that leads to invagination and budding. The PS-expressing membrane patch plays a key role in several processes like blood coagulation, phagocytosis, cell fusion and differentiation. These patches may harbor also a variety of membrane receptors acting in these processes such as tissue factor. Hence, annexin A5 can also interfere with these processes through activation of the PS-annexin A5 pinocytic pathway that leads to the downregulation of membrane receptors embedded in the PSexpressing membrane patch. This has been demonstrated for tissue factor as an example of a more generic autocrine/paracrine function of annexin A5 in the regulation of the membrane receptor repertoire of cells that have exposed $\mathrm{PS}^{15}$.

\section{POTENTIAL ROLE FOR ANNEXIN A5 IN THE CARDIOVASCULAR SYSTEM?}

An interesting aspect of the binding of annexin A.5 to externalized PS is that this may offer the cells protection from being recognized by professional phagocytes, since extemalized PS is necessary for engulfment of apoptotic cells and serves as an "eat me" signal. Recent clinical studies have shown that plasma annexin A5 levels are elevated in patients with acute myocardial infarction ${ }^{5}$. These data suggest that annexin A5 may serve as an acute phase 
reactant, which may save cells that are susceptible to engulfment. It also seems justified to hypothesize that exogenously administered annexin A5 may accelerate internalization of externalized PS. The data on the internalization of PS in the presence of annexin A5 indicate that internalization is not the result of scrambling of isolated PS molecules but results from invagination and vesicle formation of membrane patches exposing PS. Our unpublished in vitro data further indicate that the perimuclear vesicles in an increased hypercalcemic intracellular milieu may prevent cytochrome $c$ release from mitochondria adding another functional consequence to the activation of the PS-annexin A5 pinocytic pathway at least in ischemic heart muscle cells. This functional aspect requires further investigation.

In CHAPTER 5, we investigated whether the internalization of annexin A5 would have some influence on the removal of apoptotic cells. Our results showed that annexin A5 inhibits phagocytosis when present during the process of apoptosis This could not only be explained by the inhibition of apoptotic body formation since mutants of annexin A5 which inhibited apoptotic body formation were not able to inhibit phagocytosis. Our data indicate that neither shielding of $P S_{\text {, }}$ which acts as a trigger for uptake of apoptotic cells by macrophages nor the inhibition of apoptotic body formation is sufficient to inhibit phagocytosis. Together with our previously reported data that annexin A5 internalizes PScontaining membrane patches, we conclude that the PS-annexin A5 pinocytic pathway is activated early after the onset of apoptosis. We hypothesize that this activation results in the downregulation of surface receptors and/or proteins necessary for recognition and subsequent uptake by macrophages.

\section{POTENTIAL ROLE FOR ANNEXIN A5 IN THE TUMOR MICROENVIRONMENT?}

Since apoptosis plays a crucial role in the pathogenesis and treatment of cancer, and since the annexin A5 levels are upregulated in the tumor microenvironment, a function for annexin A5 in the tumor biology may be envisioned. Recently, it was reported that annexin A5-coated irradiated tumor cells elicit a long lasting tumor specific cytotoxic $T$ lymphocyte response ${ }^{16}$. In this regard, annexin A5 treatment may therefore be useful to enhance the antitumor response of the immune system and may also increase the efficiency of apoptotic cell-based vaccines, e.g. tumor vaccines ${ }^{17,18}$. Another important antitumor effect of annexin A5 may be related to its role in phagocytosis. Phagocytosis also plays an important role in tumor biology and in the development of novel anti-tumor drugs. We found that the annexin A5 - PS 
interaction influences the removal and engulfment of apoptotic cells. In this thesis, we found that administration of annexin A5 during initiation and execution of apoptosis inhibits phagocytosis. Together with our previously reported data that annexin A5 internalizes PS-containing membrane patches, we hypothesize that annexin A5 downregulates surface receptors and/or proteins necessary for recognition and subsequent uptake by macrophages. These findings may have important implications for the use of annexin A5 as an anti-tumor drug.

\section{EPILOGUE}

To date, annexin A5 is widely used as an excellent research and diagnostic tool to detect apoptotic cell death in animal models as well as in patients. As such, it has been successfully used in the field of cardiology, oncology and vascular biology. Moreover, the annexin A5-imaging technique can be applied to assess the therapeutic value of novel cell protective (cardiac) or cell death inducing (cancer) drug candidates. We are beginning to learn more about the biological activities of annexin $A 5$ as is demonstrated by the disclosure of the PS-annexin A5 pinocytic pathway in this thesis. In combination with our experiences with annexin A5 as a molecular imaging tool in vivo in animal models and in patients this opens novel insights and avenues for the clinical use of annexin A5. Its use as a therapeutic tool to treat cardiovascular diseases and cancer is now more realistic than ever.

\section{ANNEXIN A5 AS A TARGETING/DRUG DELIVERY TOOL}

Targeted drug delivery is the most important goal of pharmaceutical research and development. Drug targeting can be achieved by physical, biological, or molecular systems that result in high concentrations of the pharmacologically active agent at the pathophysiogical relevant site. If successful, the targeting would result in a significant reduction in drug toxicity, dose, and increased treatment efficacy. However, successful drug targeting is a very complicated problem. There are a number of important parameters to be considered in designing drug targeting tools. First, the drug targeting tool has to be targeted specifically to the pathophysiogical relevant site, bind to it with high affinity and 
specificity. Second, it has to enter the targeted cell and finally, it has to release the drug into the cell.

Does annexin A5 meet the requirements to be used as a drug targeting tool?

Recently, the development of a variant of annexin A5 by Dr. C. Reutelingsperger opened novel opportunities for the use of annexin A5 not only as a molecular imaging device but also as a drug targeting device. The variant of annexin A.5 makes coupling to drugs or carriers of drugs easier without impairing the PS-binding activity of the annexin A5. The variant of annexin A5 coupled to drugs, carriers of drugs, intelligent linkers and biological active (poly) peptides can be used for efficient targeted therapy. This drug targeting property of annexin A5 allows the lowering of the amount of administered drugs without decreasing the amount of drugs accumulating at the pathophysiogical relevant site for example after chemotherapy to the tumor and after ischemic damage to cardiomyocytes. The advantage is that the systemic toxicity of drugs will be considerably reduced. Another important parameter for successful outcome/treatment efficacy not only implies specific binding to the site of interest but appropriate entry of the drug into the cell. This will further improve the reduction of drug toxicity and dose. The data described in chapter 4 , that annexin A5 enters the PS-exposing cell, provides a novel therapeutic application for annexin A5 not only as a drug carrier but also as a cell entry mediator due to its internalization properties.

Molecular imaging coupled to drug targeted therapy represents a novel feature for controlled drug release allowing one to estimate local drug concentrations and to follow in time the efficacy of treatment.

\section{GENERAL CONCLUSION}

The data described in this thesis set the stage for a dual approach to use annexin A5 as a clinical application: i) as a diagnostic tool to detect apoptotic cell death and ii) as a therapeutic agent, to deliver drugs specifically to apoptotic cells, such as tumors. This dual approach may result in a combination of the two modalities in one procedure wherein diagnosis and therapy concur. 


\section{REFERENCES}

1. Reutelingsperger $\mathrm{CP}$, Hornstra $\mathrm{G}$, Hemker $\mathrm{HC}$. Isolation and partial purification of a novel anticoagulant from arteries of human umbilical cord. Eur $J$ Biochem, 1985; 151: $625-629$.

2. Romisch $₫$, Seiffge $D$, Reiner $G$, Paques EP, Heimburger $N$, In-vivo antithrombotic potency of placenta protein 4 (annexin V). Thromb Res, 1991; 61: 93-104.

3. van Heerde $W L$, de Groot $P G$, Reutelingsperger $C P$. The complexity of the phospholipid binding protein Annexin V. Thromb Haemost, 1995; 73: 172-179.

4. Keniis $H$, Doggen CJ, Vos HL, Reutelingsperger CP, Van Heerde WL, The C-1T mutation in the annexin A5 Kozak sequence slightly increases the risk of myocardial infarction in men. J Thromb Haemost, 2003; 1: 2688-2689.

5. Kaneko N, Matsuda R, Hosoda $S$, Kajita $T$, Ohta $Y$, Measurement of plasma annexin $\mathrm{V}$ by ELISA in the early detection of acute myocardial infarction. Clin Chim Acta, 1996; 251: 65-80.

6. Matsuda $R$, Kaneko $N$, Kikuchi $M$, Chiwaki $F$, Toda $M$, leiri $T$, Horikawa $Y$, Shimizu $M$, Shimamoto $K$, Clinical significance of measurement of plasma annexin $V$ concentration of patients in the emergency room. Resuscitation, 2003, 57:171-177.

7. Gonzalez-Conejero $R$, Corral J, Roldan V, Martinez C, Marin F, Rivera $J$, Iniesta JA, Lozano ML, Marco $P$, Vicente $V$, A common polymorphism in the annexin $V$ Kozak sequence $(-1 C>T)$ increases translation efficiency and plasma levels of annexin $\mathrm{V}$, and decreases the risk of myocardial infarction in young patients. Blood, 2002; 100: 2081-2086.

8. Van Heerde $W L$, Kenis $H$, Schoormans S, Lap P, Reutelingsperger CP, GonzalezConejero $R_{\text {, Corral }} \mathrm{J}$, Roldan $\mathrm{V}$, Martinez $\mathrm{C}$, Marin $\mathrm{F}$, Rivera J, Iniesta JA, Lozano $M L$, Marco $P$, Vicente $V$, The $-1 C>T$ mutation in the annexin A5 gene does not affect plasma levels of annexin A5. Blood, 2003; $101: 4223-4224$.

9. Rand $\mathrm{JH}_{1}$ Wu XX, Andree HA, Ross JB, Rusinova $E$, Gascon-Lema MG "Calandri C. Harpel PC, Antiphospholipid antibodies accelerate plasma coagulation by inhibiting annexin- $V$ binding to phospholipids: a "lupus procoagulant" phenomenon. Blood, 1998; 92: 1652-1660.

10. Rand $J H$, The pathogenic role of annexin- $V$ in the antiphospholipid syndrome. Curr Rheumatol Rep, 2000; 2: 246-251.

11. Rand $J H, W u X, X$ Andree HA, Lockwood C.l, Guller S, Scher J, Harpel PC, Pregnancy loss in the antiphospholipid-antibody syndrome--a possible thrombogenic mechanism. N Engl J Med, 1997; 337: 154-160.

12. Bevers EM, Janssen MP, Willems $G$, Zwaal RF, No evidence for enhanced thrombin formation through displacement of annexin $V$ by antiphospholipid antibodies. Thromb Haemost, 2000; 83: 792-794.

13. Van Heerde WL, Reutelingsperger CP. Maassen $C$, Lux $P$, Derksen RH, De Groot $P G$, The presence of antiphospholipid antibodies is not related to increased levels of annexin A5 in plasma. J Thromb Haemost, 2003; 1: 532-536.

14. Arai $T$, Matsubayashi $H$, Sugi $T$, Kondo $A$, Shida $M$, Suzuki $T$, Izumi SI, Mcintyre JA, Makino T, Anti-annexin A5 antibodies in reproductive failures in relation to antiphospholipid antibodies and phosphatidy/serine. Am J Reprod Immunol, 2003; 50: 202-208.

15. Ravassa $S$, Bennaghmouch $A$, Kenis $H$, Lindhout $T$, Hackeng $T$, Narula J, Hofstra $L$, Reutelingsperger C, Annexin A5 Down-regulates Surface Expression of Tissue 
Factor: a novel mechanism of regulating the membrane receptor repertoir. I Biol Chem, 2005; 280: 6028-6035.

16. Gaipl US, Beyer TD, Baumann 1, Voll RE, Stach CM, Heyder P. Kalden JR, Mantredi $A_{0}$ Herrmann $M$. Exposure of anionic phospholipids serves as antiinflammatory and immunosuppressive signal-implications for antiphospholipid syndrome and systemic lupus erythematosus. Immunobiology, 2003; 207: 73-81.

17. Stach CM, Turnay $X$, Voll RE, Kem PM, Kolowos W, Beyer TD, Kalden JR, Hermann $M_{3}$ Treatment with annexin $V$ increases mmunogenicly of apoptotic human T-cells in Balb/c mice. Cell Death Differ, 2000; 7: 911-915.

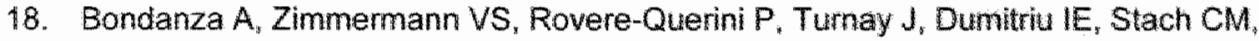
Voll RE, Gaipl US, Berting W, Posch $E_{3}$ Kalden JR, Manfredi AA, Hermann M, Inhibition of phosphatidylserine recognition heightens the immunogenicity of irradiated ymphoma cells in vivo. J Exp Med, 2004;200;1157-1165. 



\section{SUMMARY}

When we started the work presented in this thesis, it was unknown if and how binding of annexin A5 would affect the cell membrane dynamics during apoptosis. The data described in this thesis suggest that the typical cell membrane changes that occur during apoptosis, such as membrane blebbing and rapid exposure of PS, may play a role in thrombus formation, and may also be crucial in the removal of apoptotic cells from tissue. Based on observations that show enhanced thrombus formation occurring in patients with antiphospholipid antibodies and that demonstrate a high frequency of arterial and venous thrombosis occurring in patients with anti-annexin $A 5$ antibodies, we hypothesized that there exist a relation between the levels of annexin A5 and the risk of cardiovascular diseases. In addition, since PS exposure is an essential mechanism in phagocytosis of apoptotic cells, we hypothesized that annexin A5 - PS interaction influences the removal and engulfment of apoptotic cells. In this thesis, we took a stepwise approach to investigate the influence of annexin $A 5$ binding to the apoptotic plasma cell membrane.

In CHAPTER 2 we obtained more insight in the physiological significance of annexin A5 in cardiovascular diseases by a genetic approach. Genetic alterations are often associated with diseases. Since annexin A5 is an anticoagulant protein with an antithrombotic activity in vivo, a possible role for annexin $A 5$ in the antithrombotic arm of the haemostatic balance has been proposed. Accordingly, genetically caused defects of annexin A5 may be a genetic risk factor for thrombotic disorders. Therefore, we screened the annexin A5 gene for mutations in patients with venous thrombosis. The screening revealed several mutations under which the $\mathrm{C}-1 \mathrm{~T}$ mutation. To obtain more insight into the relevance of this mutation in thrombotic disorders, we validated this mutation in two large case-control studies, of venous thrombosis and myocardial infarction. We found no risk of venous thrombosis for the T-variant, but a slightly increased risk of myocardial infarction, especially in young men. Interestingly, we found that the presence of the thrombophilia factors, factor $V$ Leiden or the prothrombin 20210A mutation, increased the risk of myocardial infarction for the $T$ allele carriers about three-fold ${ }_{\text {o }}$ indicating the existence of a relationship between annexin A5 and arterial thrombosis. The molecular basis of this relationship remains to be investigated but it is unlikely that this involves 
circulating annexin $\mathrm{A5}$, because we found no association between the various alleles and annexin A5 levels.

The next chapters were aimed to unravel the role of annexin A5 in cell membrane biology during apoptosis. In CHAPTER 3, we attempted to define whether PS externalization in the heart occurs before or after the point of no return in the cell death program by using the annexin $A 5$ imaging technique. It has always been thought that once the process of cell suicide has passed a certain point, it is irreversible. However, by using a brief cardiac ischemia protocol in vivo we observed that annexin A5 binds to cells in the ischemic area, but that these cells do not die in the subsequent days. In addition, we observed that the binding of annexin A5 to these cells was associated with activation of caspase 3, which is thought to be one of the key executioners of apoptosis. Yet, these data indicate that cardiomyocytes can recover from the initiation of apoptosis, if reperfusion is restored rapidly enough, which provide an entirely novel concept to rescue mammalian cells. Moreover, the PS exposure persists at least 24 hours after the brief ischemic insult, making it possible to identify patients at risk, who are admitted the first 24 hours after an episode of chest pain. Another observation was that the cardiomyocytes, which were triggered by a short ischemic episode, bound and internalized annexin A5. In CHAPTER 4, we unraveled the mechanism of the annexin A5-induced internalization by performing in vitro studies of Jurkat cells executed to undergo apoptosis in the presence of annexin A5. Based on these data, we demonstrated that annexin A5 binds to the cell surface expressed phosphatidylserine and subsequently induces its own internalization due to the crystallization of annexin A5 at the cell membrane. A pinocytic pathway is activated involving pinocytic vesicle closure, detachment from the plasma membrane and cytoskeleton-dependent trafficking in the cytosol of the cell. These data confirmed the in vivo observations in the brief ischemia/reperfusion model. Now, to further understand whether the internalization of annexin A5 would have some influence on the phagocytosis of apoptotic cells, we developed a flow cytometric-based phagocytosis assay (CHAPTER 5). Our results showed that annexin A5 only partially inhibits phagocytosis when present at the time of macrophage-apoptotic cell interaction. On the other hand, when Jurkat cells process through apoptosis in the presence of annexin A5, a more then two-fold increase in inhibition was observed. This could not only be explained by the inhibition of apoptotic body formation since mutants of annexin A5 which inhibited apoptotic body formation were not able to inhibit phagocytosis. Our data indicate that neither shielding of PS, which acts as a trigger for the uptake of apoptotic cells by macrophages nor the inhibition of apoptotic bodies formation is sufficient to inhibit phagocytosis. 
Together with our previously reported data that annexin A5 but not M23 internalizes PS-containing membrane patches, we hypothesize that the inhibitory action of annexin A5 is not based on the physical shielding of PS but on the internalization of the PS-expressing membrane patch that harbors a complex collection of "eat me" signals.

\section{FINAL CONCLUSION}

The data described in this thesis provide novel insights into the role of annexin A5 in the membrane biology during apoptosis. Annexin A5 affects the cell membrane biology of PS exposing cells not only by binding but subsequently internalizing membrane patches which contain potential proteins/receptors involved in several membrane-associated processes, such as blood coagulation and phagocytosis. These findings may provide a dual approach for the use of annexin A5 in the clinic: as a diagnostic tool to detect apoptotic cell death and as a therapeutic agent and/or targeting tool to deliver cardio-protective (myocardial infarction) or cell death inducing (cancer) drugs to the site of cell death. 



\section{SAMENVATTING}

Bij de aanvang van dit onderzoek was het nog onbekend of de binding van annexine A5 aan de celmembraan tijdens apoptose een invloed heeft op de dynamiek van de celmembraan. De resultaten beschreven in dit proefschrift suggereren dat de typische celmembraanveranderingen die optreden tijdens apoptose, zoals membraan uitstulping, en expositie van phosphatidylserine (PS) aan het celoppervlak, niet alleen een rol spelen tijdens de bloedstolling maar ook tijdens de opruiming van dode cellen in het weefsel. Gebaseerd op het feit dat patienten met anti-fosfolipide antilichamen een verhoogde kans hebben op de vorming van bloedklonters en dat patiënten met anti-annexine A5 antilichamen een verhoogd risico op arteriële en veneuze trombose hebben, leidde tot onze hypothese dat er een relatie bestaat tussen de hoeveelheid annexine $A 5$ in de circulatie en het risico op cardiovasculaire aandoeningen. Vermits PS een belangrijke rol speelt bij de opruiming van dode cellen, vermoeden wij dat de interactie van annexine A5 met PS een invloed zal hebben op de opruiming van dode cellen. In dit proefschrift hebben we stapsgewijs de binding van annexine A5 aan de celmembraan tijdens apoptose onderzocht.

In HOOFDSTUK 2 hebben we getracht meer inzicht te krijgen in de fysiologische betekenis van annexine A5 met name in cardiovasculaire aandoeningen door middel van gen mutatie analyse. Genetische defecten zijn vaak de oorzaak van bepaalde ziekten. Aangezien annexine $\mathrm{A} 5$ een antistollingseiwit is met een antitrombotische activiteit in vivo is een mogelijke rol voor annexine A5 in de antitrombotische arm van de hemostatische balans weggelegd. Met als gevolg dat annexine A5 een potentiële genetische risico factor kunnen zijn in tromtische aandoeningen. Om dit te onderzoeken hebben we het annexine A5 gen gescreend op mutaties in patiënten met veneuze trombose. De screening leverde verscheidene mutaties op waaronder de C-1T mutatie. Om meer inzicht te krijgen in de relevantie van deze mutatie hebben we deze mutatie verder gevalideerd in twee grote case-control studies van veneuze trombose en myocard infarct. We hebben geen risico voor veneuze trombose voor de $T$ variant gevonden maar wel een licht verhoogd risico op het krijgen van een myocard infarct, vooral bij jonge mannen. Bovendien hebben we een drievoudig verhoogd risico gevonden voor myocard infart voor de T-variant in aanwezigheid van andere trombofilie factoren, zoals factor $V$ Leiden en de 
prothrombine 20210A mutatie. De moleculaire basis voor deze relatie moet nog verder onderzocht worden maar het is onwaarschijnlijk dat circulerend annexine A5 hierbij betrokken is, gezien we geen verband gevonden hebben tussen de verschillende allelen en de annexine A5 spiegels in het bloed.

In de volgende hoofdstukken hebben we de rol van annexine A5 in de celmembraan biologie tijdens apoptose onderzocht. In HOOFDSTUK 3 hebben we met behulp van de annexine A5 imaging techniek getracht te bepalen of PS externalisatie in het hart gebeurt vór of na het 'point of no return' in het celdoodprogramma. Men heeft altijd al vermoed dat wanneer het celdoodprogramma een bepaald punt heeft gepasseerd het onomkeerbaar is. Wij hebben aangetoond dat na een korte periode van ischemie annexine A5 bindt aan cellen in het ischemische gebied en dat deze cellen in de daaropvolgende dagen niet dood gaan. Bovendien hebben we aangetoond dat de binding van annexine $A 5$ aan deze cellen gepaard gaat met de activatie van caspase 3, een van de "executioners" van het celdoodprogramma. Deze data tonen aan dat hartspiercellen kunnen herstellen van celdood wanneer de bloedtoevoer maar snel genoeg hersteld wordt. De PS expositie duurt minstens 24 uur na een korte periode van ischemie. Dit maakt het mogelijk om patiënten met een verhoogd risico te identificeren die gehospitaliseerd zijn binnen de 24 uur na een periode van pijn op de borst. Een andere waarneming is dat cardiomyocyten die getriggerd zijn door een korte ischemische periode annexine A5 binden en internalizeren. In HOOFDSTUK 4 hebben we het mechanisme van de annexine A5 gemedieerde internalisatie ontrafeld met behulp van in vitro studies in Jurkat cellen die geinduceerd zijn tot celdood in aanwezigheid van annexine A5. We hebben aangetoond dat annexine A5 bindt aan het celoppervlak van PS exposerende cellen en vervolgens geinternaliseerd wordt door de twee-dimensionale crystallisatie van annexine A5 op de celmembraan. Een pinocytotische route is geactiverd die leidt tot de vorming van een pinocytotisch vesikel gevolgd door afsnoering van het vesikel van de plasmamembraan en cytoskeleton-afhankelijk transport door het cytosol van de cel. Deze resultaten bevestigen de bevindingen van de in vivo ischemie/reperfusie studies. Om na te gaan of de internaliszatie van annexine A5 een invloed heeft op de opruiming van dode cellen hebben we een flow cytometrische phagocytose assay ontwikkeld (HOOFDSTUK 5). Onze resultaten tonen aan dat annexine A5 de opruiming van dode cellen maar gedeeltelijk remt indien aanwezig tijdens de macrofaag-dode cel interactie. Daarnaast hebben we aangetoond dat wanneer annexine A5 aanwezig is tijdens de initiatie van het celdoodprogramma de opruiming van dode cellen voor meer dan de helft wordt geremd. Deze remming was niet te verklaren door de 
remming van apoptotische body vorming omdat mutanten van annexine $\mathrm{A} 5$ die de apoptotische body vorming verhinderen niet in staat waren de opruiming van dode cellen te remmen. Op basis van deze waarnemingen stellen we vast dat afschermen van PS door annexine A5 en de remming van de vorming van apoptotische lichamen niet voldoende is om de opruiming van dode cellen te remmen. Samen met onze eerdere beschreven resultaten dat annexine A5 PS positieve membraan patches internaliseert, vermoeden wij dat het remmende effect van annexin A5 niet enkel gebaseerd is op het afdekken van PS maar ook op de internalisatie van PS exposerende membraan patches die een complex gamma van "eat me" signalen bevatten.

\section{ALGEMENE CONCLUSIE}

De resultaten beschreven in deze thesis geven ons nieuwe inzichten in de rol van annexine A5 in de membraan biologie tijdens apoptose. Annexine A5 heeft een invloed op de celmembraan biologie van PS exposerende cellen niet alleen door er aan te binden maar ook door membraan patches te internaliseren die mogelijk belangrijke eiwitten en/of receptors bevatten die betrokken zijn bij verscheidene membraan geassocieerde processen zoals bijvoorbeeld de bloedstolling en de opruiming van dode cellen.

Onze resultaten leiden tot een tweeledige toepassing voor annexine A5 in de kliniek: als een diagnosticum voor de detectie van dode cellen en als een therapeuticum en/of targeting agent om schermende of celdood inducerende geneesmiddelen af te leveren op de plaats van celdood. 


$$
\text { . }
$$




\section{DANKWOORD / ACKNOWLEDGEMENTS}

Als $u$ op deze pagina bent geraakt dan zult $u$ wel begrijpen dat ik ze onmogelijk allemaal zelf heb kunnen schrijven zonder de hulp en inspiratie van anderen, die ik hieronder van harte wil bedanken.

Allereerst natuurlijk dank aan mijn co-promotoren, Chris Reutelingsperger en Leo Hofstra. Chris, als dagelijkse begeleider heb je me heel wat wijsheid bijgebracht. Voor van alles en nog wat had je wel een of ander spreekwoord voor me klaar! Ik heb enorm veel van je geleerd; de manier van schrijven, een kritische blik op resultaten en noem maar op. De vrijheid die je me gaf heeft ertoe geleid dat ik nu "mijne plan kan trekken". En je hebt heel wat stukjes van mij langs zien komen, die je iedere keer weer van de nodige gedetallieerde commentaar voorzag "...lies behind..." Heidi: "How far behind???", bedoel je niet: "... underlies..." om er maar een te noemen. Leo, bedankt voor je advies, scherpe inzichten en je positieve feedback.

Mijn promotor, Jan Rosing heeft ervoor gezorgd dat de Nederlandstalige samenvatting er op z'n nederlands uitziet en niet op z'n vlaams.

Professor Narula, dear Jagat, you learned me to look further then only basic science, to lay a link between basis science and clinical application.

Carine Doggen, Frits Rosendaal, Hans Vos, Rogier Bertina en Waander van Heerde, bedankt voor de leerrijke discussies, de statistiek en de kritische blik op hoofdstuk 2.

De leden van de beoordelingscommissie wil ik bedanken voor de tijd en moeite die ze hebben genomen om mijn proefschrift te beoordelen.

Naast mijn promotoren en co-promotoren, hebben ook veel andere collega's een steentje bijgedragen aan dit proefschrift. Zonder de hulp van ons uniek labje met de al even unieke mensen, Petra, Niko, Liset, Hugo, Cecile, Susanna en Kristof, was het niet gelukt. Nog nooit heb ik zo'n verschillende karakters zo goed met elkaar zien samenwerken.

Bij de collega's van de afdeling Biochemie kon/kan ik altijd terecht met een of andere vraag in verband met de bloedstolling. De collega's van de Cardio/Farmacologie (Abdel, Bas, Johan, Sander, Maarten, Jules, Susanne en Veerle) bedankt voor de gezellige sfeer bij jullie en de enorme pret in snowworld.

Nicole (paranimf), zonder jouw expertise met de muisjes was hoofdstuk 3 nooit tot stand gekomen. I hoop in de toekomst nog veel experimentjes met je samen te kunnen doen en het tripje naar de Provence nog eens over te doen!

Jenny (paranimf), zonder jouw is het nu wel erg rustig op ons kamertje. Bedankt voor de gezellige babbeltjes op ons kamertje maar ook in Café Zuid 
met de nodige glaasjes witte wijn erbij; voor het luisterende oor en de steun in moeilijke tijden; voor de gezellige business-tripjes naar Wenen, Montpellier en Toulouse. I $k$ wens je een spetterende carrière in Londen.

Promoveren kan uiteraard niet zonder ontspanning! Mijn tennisploegske, Elke, Fanny, Annick, Lauren, Joyce, Shana, coach Geert en onze mascotte Emilie wil ik hierbij bedanken voor de fantastische teamspirit. Intensieve trainingen in de winter en supergezellige interclubs in het voorjaar hielden mijn "geest" maar vooral mijn lichaam in topconditie. Jammer dat ik in september tijdens de eindronde van de interclub niet kan meedoen, maar jullie hebben alvast 2 hevige supporters aan de kant staan. En was het niet zo dat de beste stuurlui aan wal staan ;-). Volgend jaar, hebben we er in ieder geval een mascotte bij!!!

Dan hebben we nog de "GO-FITters" Ann, Karine, Jo, Sven en mijn schatje of beter gezegd "HO7-RN-F" of zullen we er toch maar de "Duveltjes" van maken. Jullie brengen mijn stelling nr. 9 volledig tot zijn recht! Zonder jullie had ik nooit de dodentocht uitgelopen, was de 24 uur mountainbike van Westerlo nooit zo geslaagd geweest, en werden op vrijdagavond de vochtreserves na een zware les spinning van den Tom nooit zo snel weer op peil gebracht met uiteraard ons "lievelingsdrankske"!

Verder will ik nog mijn ouders bedanken voor de gelegenheid die ze mij hebben gegeven om mijn eigen weg te vinden, zonder enige druk. Zij hebben me altijd gesteund in mijn studiekeuze, hoewel ze af en toe wel eens de volgende woorden lieten vallen: "Waar ben je toch in godsnaam aan begonnen?", ...Maastricht!!! "Is er echt niks hier in de buurt wat u interesseert?". Ook mijn schoonouders en grootouders wil ik heel erg bedanken voor hun steun en interesse in mijn werk. Karin, mijn schoonzus, bij deze wil ik je bedanken voor je enthousiasme en enorme medeleven naar de geboorte toe.

Het drukken van een proefschrift is enorm kostbaar. Bij deze wil ik dan ook al mijn sponsoren bedanken voor hun genereuze bijdrage in de drukkosten. Met name Sjaak Deckers en Hans Hofstraat (Philips Medical Systems); Peter Moonen en Ad Vermaire (Nexins Research); Leica Microsystems en de Stichting RESCAR.

Last but not least, Carl, mijn beste vriend, man, "future daddy", ik wil je bedanken voor alles, maar dan ook echt alles!

Tenslotte wil ik nog iedereen bedanken, die ik vergeten ben. "Vergeetachtigheid" is naar het schijnt een zwangerschapskwaaltje, mede veroorzaakt door een afname van DHA, een vetzuur in de hersenen van de moeder. Hierdoor zou het hersenvolume afnemen! Maar dit is slechts een mager excuus, nietwaar? 


\section{ABOUT THE AUTHOR}

Heidi Kenis was born on October $3^{\text {rd }}, 1975$ in Herentals, Belgium. She completed her secondary education at the Heilig-Hart-College in Heist-op-denBerg in 1994. In 1996 she obtained her Bachelor degree in Chemistry at the University of Leuven, Belgium. In 1996 she started to study Biochemistry, with as specialisation Molecular Biology. She obtained her Master degree in Biochemistry on July $7^{\text {th }}, 1998$. In February 1999 she started, under supervision of Dr. C. Reutelingsperger, as a PhD student at the department of Biochemistry at the University of Maastricht, the Netherlands.

Heidi Kenis werd geboren op 3 oktober 1975 te Herentals in België. In 1994 behaalde ze haar diploma voor het secundair onderwijs aan het Helig-HartCollege te Heist-op-den-Berg. In 1996 haalde ze het diploma Kandidaat in de Scheikunde aan de Katholieke Universiteit Leuven in België. In 1996 begon ze met haar studie Biochemie met als specialisatie Moleculaire biologie. Op 7 juli 1998 behaalde ze haar doctoraal examen. In februari 1999, starte zij, onder leiding van $\mathrm{Dr}$. C. Reutelingsperger, als assistent in opleiding bij de afdeling Biochemie aan de Universiteit van Maastricht in Nederland. 


\section{LIST OF PUBLICATIONS}

\section{ARTICLES}

1. Reutelingsperger CPM, Dumont $E_{\text {, Thister }}$ TW, van Genderen $H$, Kenis $H$, van de Einde $S$, Heidendal $G$, Hofstra $L$. Visuatization of cell death in vivo with the annexin A5 maging protocol. I Immunol Methods. 2002 Jul $1 ; 265(1-2): 123-32$. Review.

2. Kenis $H$, van Genderen $H$, Bennaghmouch $A$, Rinia HA, Frederik P, Narua $J_{\text {r }}$ Hofstra $L$, Reutelingsperger CPM. Cell surface expressed phosphatidylserine and Annexin A5 open a novel portal of cell entry. I Biol Chem. 2004. Dec $10 ; 279(50): 52623-9$

3. Kenis $H$, Doggen $C J$, Vos $H L$, Reutelingsperger CPM, van Heerde WL. The $C-1 T$ mutation in the annexin A5 Kozak sequence slightly increases the risk of myocarcial infarction in men. J Thromb Haemost. 2003 Dec.1 12):2688-9.

4. van Heerde $W_{L}$, Kenis $H$, Schoormans $S$, Lap P, Reutelingsperger CPM. The $1 C>T$ mutation in the annexin A5 gene does not affect plasma levels of annexin A5. Blood. 2003 May 15;101(10):4223-4; author reply 4224-5.

5. Vanschoonbeek K, Feige MA. Van Kampen RJ, Kenis $H_{3}$, Hemker HC, Giesen PL, Heemskerk JW. Initiating and potentiating role of platelets in tissue factor-induced thrombin generation in the presence of plasma: subject-dependent variation in thrombogram characteristics. J Thromb Haemost. 2004 Mar;2(3):476-84.

6. Boersma HH, Stolk LM, Kenis $H$, Deckers NM, Vanderheyden JL, Hofstra $L$, Heidendal GA, Reutelingsperger CPM.The ApoCorrect assay: a novel, rapid method to determine the biological functionality of radiolabeled and fluorescent Annexin A5. Anal Biochem. 2004 Apr 1;327(1):126-34.

7. Ravassa $S$, Bennaghmouch A, Kenis $H$, Lindhout T, Hackeng T, Narula J, Hofstra $L$, Reutelingsperger CPM. Annexin A5 downregulates surface expression of tissue factor: A novel mechanism of regulating the membrane receptor repertoire. J Biol Chem. 2005 Feb 18:280(7):6028-35. 


\section{BOOK CHAPTER}

1. van Genderen $H$, Kenis $H_{3}$ Dumont EA, van Heerde $W L$, Hofstra $L$, Reutelingsperger CPM. Membrane Alterations in Dying Cells. Book: Cell proliferation and Apoptosis. Editors: Hughes D. and Mehmet H. 2003 BIOS Scientific Publishers Ltd, Oxford p. 185-200.

\section{AWARDS}

1. Belgian Society of Thrombosis and Haemostasis Travel Grant 2001, The International Society on Thrombosis and Haemostasis congress, July 6-12, 2001, Paris, France

2. Young Investigator Travel Award, The Society for Molecular Imaging, September 912,2004 , St. Louis MO, USA 